UNIVERSIDADE DE SÃO PAULO

FACULDADE DE FILOSOFIA CIÊNCIAS E LETRAS DE RIBEIRÃO PRETO

DEPARTAMENTO DE PSICOLOGIA

PROGRAMA DE PÓS-GRADUAÇÃO EM PSICOBIOLOGIA

\title{
O Cérebro Sócio-Musical: Estudo de uma experiência de educação musical
}

ALEXANDRE ANTÔNIO MATEUS MOISÉS

Dissertação apresentada à Faculdade de Filosofia, Ciências e Letras de Ribeirão Preto da Universidade de São Paulo como parte das exigências para obtenção do título de Mestre em Ciências.

Área de Concentração: Psicobiologia.

Apoio: CAPES

Ribeirão Preto 

UNIVERSIDADE DE SÃO PAULO

FACULDADE DE FILOSOFIA CIÊNCIAS E LETRAS DE RIBEIRÃO PRETO DEPARTAMENTO DE PSICOLOGIA PROGRAMA DE PÓS-GRADUAÇÃO EM PSICOBIOLOGIA

\title{
O Cérebro Sócio-Musical: Estudo de uma experiência de educação musical
}

\author{
Alexandre Antônio Mateus Moisés \\ Orientador: Professor Doutor José Lino Oliveira Bueno
}

Dissertação apresentada à Faculdade de Filosofia Ciências e Letras de Ribeirão Preto da Universidade de São Paulo, como parte das exigências para obtenção do título de Mestre em Ciências.

Área de Concentração: Psicobiologia.

Apoio: CAPES

Ribeirão Preto 
Autorizo a reprodução e divulgação total ou parcial deste trabalho, por qualquer meio convencional ou eletrônico, para fins de estudo e pesquisa, desde que citada a fonte.

\section{FICHA CATALOGRÁFICA}

Moisés, Alexandre Antônio Mateus

O Cérebro Sócio-Musical: Estudo de uma experiência de educação musical. Ribeirão Preto, 2016.

131 p. : il. ; $30 \mathrm{~cm}$

Dissertação de mestrado apresentada à Faculdade de Filosofia, Ciências e Letras de Ribeirão Preto/USP. Área de Concentração:

Psicobiologia.

Orientador: Bueno, José Lino Oliveira

1. Educação Musical. 2.Intervenção Social. 3. Neurociências.

4. Avaliação Psicológica. 


\section{FOLHA DE APROVAÇÃO}

Moisés, Alexandre Antônio Mateus

O Cérebro Sócio-Musical: Estudo de uma experiência de educação musical

Dissertação apresentada à Faculdade de Filosofia Ciências e Letras de Ribeirão Preto da Universidade de São Paulo, como parte das exigências para obtenção do título de Mestre em Ciências.

Área de Concentração: Psicobiologia.

Aprovado em: 1

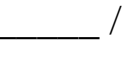

\section{Banca Examinadora}

Prof. Dr.

Instituição: Julgamento:

Assinatura:

Prof. Dr.

Instituição: Julgamento:

Assinatura:

Prof. Dr.

Instituição: Julgamento:

Assinatura: 



\section{AGRADECIMENTOS}

A todos os participantes desta pesquisa que doaram um pouco ou muito do seu tempo para que o trabalho fosse concluído.

Às Instituições que concordaram em participar do estudo: Escola Estadual Guimarães Junior, Colégio Brasil e, especialmente, Associação Amigos do Projeto Guri (AAPG) por permitirem que a pesquisa fosse realizada em suas dependências. Nominalmente, gostaria de agradecer Laissi, Taís e Maria Aparecida das escolas regulares e José Henrique da AAPG.

Aos profissionais do Projeto Guri que direta ou indiretamente participaram do andamento deste estudo. Especialmente aos profissionais que cederam seu tempo para conversas formais e informais sobre o Guri, a educação musical, o dia-a-dia e suas dificuldades. Nominalmente, José Francisco, Aline, Benê, Fernanda, Rafael e Marina.

À Mid, um agradecimento especial, por ter concedido três riquíssimos momentos de entrevistas (uma delas debaixo de muita chuva), por me convidar a conhecer o Polo da Fundação Casa, por me incentivar a realizar a pesquisa com o Projeto Guri, auxiliando com todos os trâmites burocráticos.

À equipe do Polo de Ribeirão Preto, especialmente à Patrícia e ao Rafa, que apoiaram o dia-a-dia da pesquisa, ajudando na busca por participantes, fazendo convites, auxiliando a compreensão das questões práticas, enfim, pelas supervisões conjuntas que fizemos.

Ao LabTeam pelas trocas científicas ou não. Agradeço à Sarah, Danilo, Érico, Raquel, Chico, Dani, Tati, Dudu, Victor, Boni, Ricardo, Renan, David, Márcia e Thiago.

Ao João, por estar sempre pronto para resolver os problemas das formas mais leves e tranquilas. Por fazer as impressoras funcionarem, mesmo em suas férias na véspera de ano novo!

Ao Prof. José Lino, por todo o conhecimento científico, humano e político que faz questão de compartilhar durante todos os encontros formais e informais. Por me levar para conhecer a Europa! Por me orientar por 7 anos...

À Renata, pela paciência e precisão nas informações.

À minha família, Abílio, Dulce, Henrique e Maria, por convivermos juntos ao longo da minha vida inteira e sempre estarmos juntos nas brigas e conquistas. Por sofrermos juntos e por rirmos juntos.

À minha nova família, os Frateschis, e à minha velha família, os Mateus e os Moisés.

À Mara, por estar lá. Por caminhar ao meu lado na nova família que estamos construindo. Por deixar o cotidiano especial. Por acompanhar a construção dessa dissertação linha a linha ao meu lado e cuidar dos padrões estéticos. 
Aos amigos que me auxiliaram durante minha formação, Panda, Grafite, Ob, Doug, Dani e aos que também me auxiliaram diretamente neste trabalho, Dode, Ninguém, Tevez e Marci.

Ao Programa de Pós-Graduação em Psicobiologia e à Faculdade de Filosofia Ciências e Letras de Ribeirão Preto por todo o suporte técnico.

À Capes, pelo suporte financeiro.

Obrigado! 
"sozinha o som do violino não aparece tanto, mas junto o som do violino parece que aparece mais, ele se destaca em conjunto."

(Participante do estudo, estudante de violino) 



\section{RESUMO}

Moisés, A. A. M. (2016). O Cérebro Sócio-Musical: Estudo de uma experiência de educação musical. Dissertação de Mestrado, Departamento de Psicologia, Faculdade de Filosofia Ciências e Letras de Ribeirão Preto, Universidade de São Paulo.

A prática musical tem efeitos positivos no desenvolvimento humano, envolvendo aspectos cognitivos, emocionais, motivacionais e sociais, que implicam em alterações no processamento cerebral. O número de Programas de Educação Musical (PEMs) com enfoque em populações jovens em vulnerabilidade social tem crescido no Brasil e no mundo. Dessa maneira, torna-se importante a realização de estudos que verifiquem os efeitos de PEMs no desenvolvimento destas populações. O objetivo do presente estudo é investigar os impactos de uma experiência de um PEM sobre os aspectos psicológicos de seus estudantes, mais especificamente a autoestima, as habilidades sociais e o funcionamento executivo. A coleta de dados foi realizada em um PEM da cidade de Ribeirão Preto - SP e em duas escolas regulares de ensino, uma particular e outra da rede pública. Participaram do estudo 69 crianças e adolescentes com idades entre 10 e 17 anos, divididos em três grupos, a saber: Grupo Iniciante (GI), composto por alunos com até 12 meses de matrícula no PEM; Grupo Experiente (GE), composto por alunos com mais de 24 meses de matrícula no PEM; e Grupo Controle (GC), constituído por participantes sem qualquer envolvimento com aprendizado musical. Cada grupo foi composto por 23 estudantes. Os três grupos de participantes responderam aos seguintes testes psicológicos: Escala de Autoestima de Rosenberg (EAR), Matson Evaluation of Social Skills with Youngsters (MESSY) e Teste de Stroop. Também foram realizadas entrevistas semi-estruturadas com todos os estudantes dos grupos GI e GE, dez estudantes do PEM que não compuseram nenhum grupo por não possuírem o prérequisito de tempo de matrícula exigido, seis responsáveis legais dos estudantes e doze profissionais do PEM. As entrevistas tiveram a função de fornecerem relatos verbais a respeito dos impactos percebidos nos estudantes pelo envolvimento com o PEM. Os dados dos testes psicológicos foram analisados através dos testes estatísticos ANOVA, MannWhitney e $\mathrm{t}$ de Student e as entrevistas foram analisadas através da investigação qualitativa em educação. As análises dos testes psicológicos mostraram que os GI e GE não possuem diferenças entre si para nenhuma das variáveis de estudo. O GC apresentou escores inferiores aos GI e GE para a Autoestima e escores superiores para Solidão e Ansiedade Social, indicando que o envolvimento com o PEM pode acarretar em ganhos nessas habilidades. A partir da análise das entrevistas foram construídas três categorias de codificação relacionadas a impactos comportamentais do envolvimento com o PEM, a saber: "relacionamento interpessoal", "desenvolvimento de habilidades intrapessoais" e "envolvimento com música e desenvolvimento humano na perspectiva de profissionais e responsáveis legais". A análise das entrevistas indicou que a participação no PEM está relacionada a impactos positivos na autoestima, habilidades sociais e funcionamento executivo dos participantes. Os resultados foram discutidos buscando interrelaciona-los de maneira a integrar os dados colhidos por meio dos testes psicológicos e através das entrevistas. Conclui-se que a participação em PEMs com enfoque no resgate social de populações vulneráveis possui influência no desenvolvimento de crianças e adolescentes, indicando que o uso da educação musical caracteriza uma importante estratégia de intervenção social.

Palavras-chave: Educação Musical; Intervenção Social; Neurociências; Avaliação Psicológica. 



\begin{abstract}
Moisés, A. A. M. (2016). The Socio-Musical Brain: Study of a music education experience, Dissertação de Mestrado, Departamento de Psicologia, Faculdade de Filosofia Ciências e Letras de Ribeirão Preto, Universidade de São Paulo.
\end{abstract}

The musical practice has positive effects on human development, involving cognitive, emotional, motivational and social aspects, which imply changes in brain processing. The number of Music Education Programs (MEPs) with a focus on young people in social vulnerability has grown in Brazil and worldwide. Thus, it is important to conduct studies that verify the effects of MEPs in the development of these populations. The aim of this study is to investigate the impact of an experience of a PEM on the psychological aspects of their students, more specifically self-esteem, social skills and executive functioning. Data collection was carried out in a MEP the city of Ribeirão Preto - SP and two regular education schools, one private and another in public schools. The study included 69 children and adolescents aged 10 to 17 years, divided into three groups, namely: Beginner Group (BG), composed of students with up to 12 months of enrollment in PEM; Experienced group (EG), composed of students over 24 months of enrollment in PEM; and Control Group (CG) consisting of participants without any involvement with musical learning. Each group consisted of 23 students. The three groups of participants answered the following psychological tests: the Rosenberg Self-Esteem Scale (RSS), Matson Evaluation of Social Skills with Youngsters (MESSY) and Stroop Test. They were also carried out semi-structured interviews with all students of the BG and EG groups, ten students of the MEP not composed any group for not having the registration time prerequisite required, six legal guardians of students and twelve professional of the MEP. The interviews had the function of providing verbal reports about the perceived impacts on students for their involvement with the MEP. The data of psychological tests were analyzed using statistical tests ANOVA, Mann-Whitney and $t$ Student and interviews were analyzed by qualitative research in education. The analysis of psychological tests showed that the BG and EG have no differences between them for any of the study variables. The CG showed lower scores than BG and EG for Self-esteem and higher scores for Solitude and Social Anxiety, indicating that engagement with the MEP can result in gains in these skills. From the analysis of the interviews were built three coding categories related to behavioral impacts of engagement with the MEP, namely: "interpersonal relationship", "development of intrapersonal skills" and "involvement with music and human development from the perspective of professional and legal guardians". The data analysis showed that participation in the MEP is related to positive impacts on Self-esteem, Social Skills and Executive Functioning of the participants. The results were discussed seeking interrelates them in order to integrate the data collected by means of psychological tests and through interviews. It concludes that participation in MEPs focusing on social rescue vulnerable populations have influence on the development of children and adolescents, indicating that the use of music education features an important strategy for social intervention.

Keywords: Music Education; Social intervention; Neurosciences; Psychological Evaluation. 



\section{LISTA DE FIGURAS}

Figura 1 - Distribuição dos Polos, Polos em Fundação Casa e Regionais Administrativas do Projeto Guri em todo o Estado de São Paulo.

Figura 2 - Organograma funcional sintético da Associação Amigos do Projeto Guri identificando os três níveis administrativos Sede, Regional e Polo 40

Figura 3 - Períodos de aulas do Polo do Projeto Guri de Ribeirão Preto 57 



\section{LISTA DE SIGLAS}
AAPG -
Associação Amigos do Projeto Guri
CAAE - $\quad$ Certificado de Apresentação para Apreciação Ética
CAPE - $\quad$ Cidadão, Artista, Professor e Escolar
CATS - $\quad$ Citizen, Artist, Teacher and Scholar
CLT - $\quad$ Consolidação das Leis do Trabalho
CMDCA - Conselho Municipal dos Direitos da Criança e do Adolescente
EAR - $\quad$ Escala de Autoestima de Rosenberg
ECA - $\quad$ Estatuto da Crianças e do Adolescente
FEBEM - $\quad$ Fundação Estadual do Bem Estar do Menor
FESNOJIV - Fundación del Estado para el Sistema Nacional de las Orquestas Juveniles e Infantiles de Venezuela
FPS - $\quad$ Funções Psicológicas Superiores
FundaMusical - Fundácion Musical Simón Bolívar
GC - $\quad$ Grupo Controle
GE - $\quad$ Grupo Experiente
GG - $\quad$ Grupo Guri
GI - $\quad$ Grupo Iniciante
LGBT - $\quad$ Lésbicas, Gays, Bissexuais, Travestis, Transsexuais e Trasnsgêneros
MESSY - $\quad$ Matson Evaluation of Social Skills With Youngsters
MOVE - $\quad$ Musicians and Organizers Volunteer Exchenge
NEOJIBA - Orquestrando a Vida, Núcleos Estaduais de Orquestras Juvenis e Infantis da Bahia
ONG - $\quad$ Organização Não Governamental
PEM - $\quad$ Projeto de Educação Musical
TA - $\quad$ Termo de Assentimento
TCLE - $\quad$ Termo de Consentimento Livre e Esclarecido
UF - $\quad$ Unidade Funcional 



\section{SUMÁRIO}

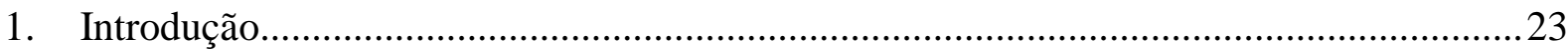

1.1. O desenvolvimento humano e sua interface com a educação...................................23

1.2. A atividade musical e o cérebro: Impactos da música para o ser humano ................27

1.3. Música, educação e educação musical ..................................................................28

1.4. Programas de Educação Musical com enfoque em intervenção social e seus impactos

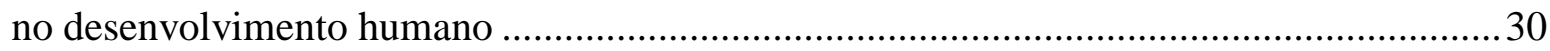

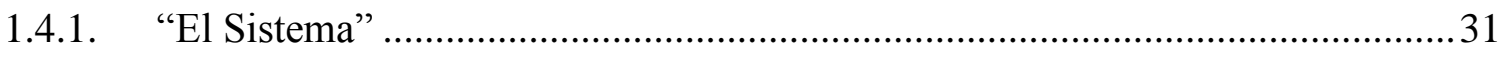

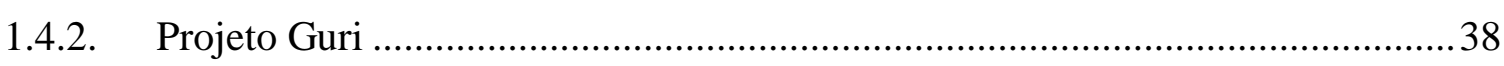

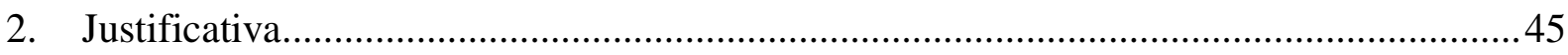

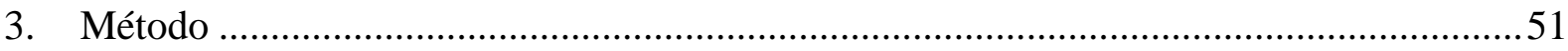

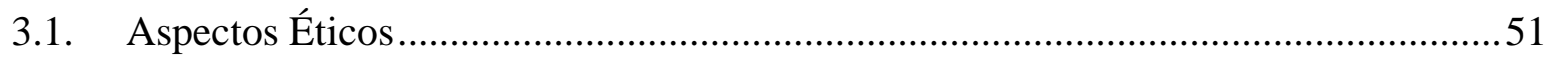

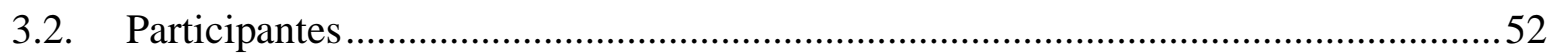

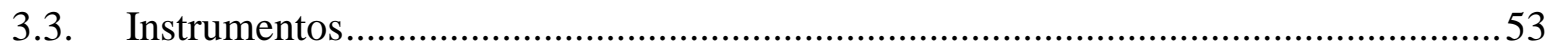

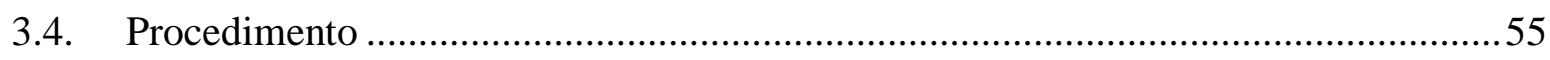

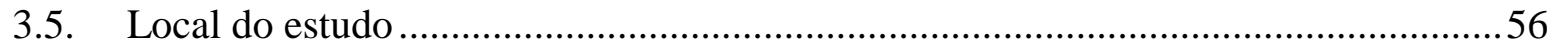

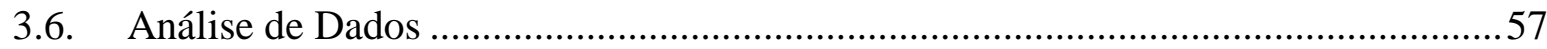

3.6.1. Análise dos testes psicológicos.......................................................................57

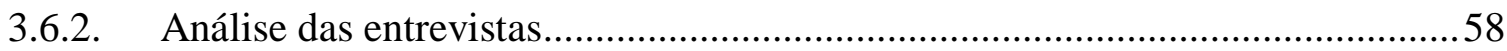

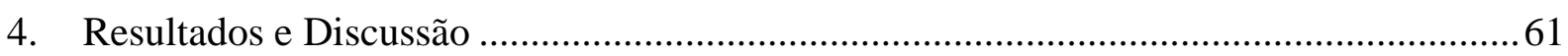

4.1. Caracterização e análise institucional a partir da perspectiva dos profissionais ........61

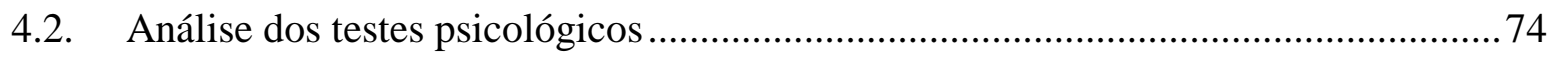

4.3. Análise das entrevistas: Indicadores de estados psicológicos e fatores de contexto .77

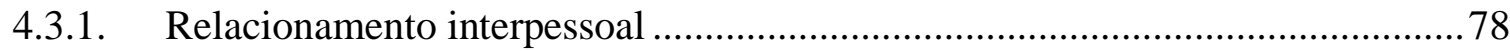

4.3.2. Desenvolvimento de habilidades intrapessoais ................................................ 81

4.3.3. Envolvimento com música e desenvolvimento humano na perspectiva de

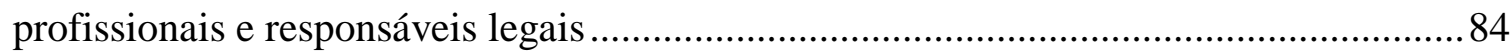

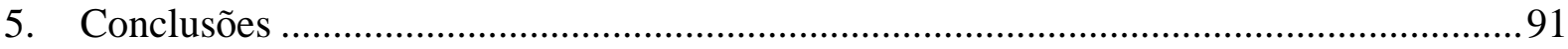

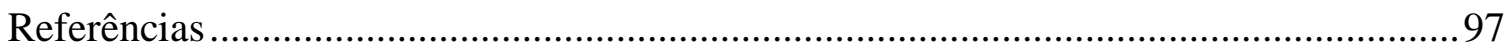

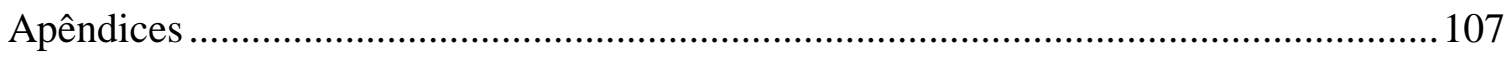

Apêndice 1 - Termo de Consentimento Livre e Esclarecido (Estudantes) ........................ 107

Apêndice 2 - Termo de Consentimento Livre e Esclarecido (Responsáveis Legais e

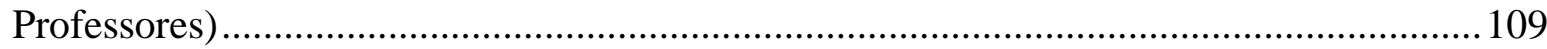

Apêndice 3 - Termo de Assentimento ............................................................................... 111 
Apêndice 4 - Roteiro de entrevista aos estudantes ........................................................... 113

Apêndice 5 - Roteiro de entrevista aos responsáveis legais ............................................ 114

Apêndice 6 - Roteiro de entrevista aos professores .................................................. 115

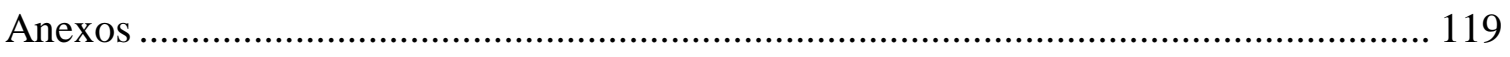

Anexo 1 - Carta de manifestação de concordância - Projeto Guri ...................................... 119

Anexo 2 - Carta de manifestação de concordância - Escola Estadual Dr. Guimarães Junior .

Anexo 3 - Carta de manifestação de concordância - Colégio Brasil ............................... 121

Anexo 4 - Escala de Autoestima de Rosenberg …........................................................ 122

Anexo 5 - Matson Evaluation of Social Skills with Youngsters ..................................... 123

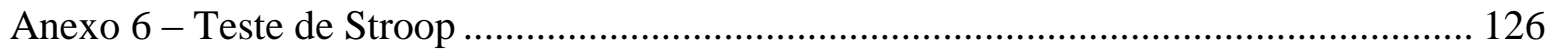





\section{Introdução}

A música está presente na história da humanidade há mais de 50.000 anos, possuindo uma infinidade de inter-relações com os hábitos dos seres humanos. A experiência musical compõe diversos momentos da vida das pessoas, dos mais cotidianos aos mais singulares como casamentos, festas e rituais religiosos. Além disso, seus usos não se restringem a tais ocasiões, podendo ser usada também como forma de intervenções médicas, psicológicas e educacionais (Levitin, 2008).

Este estudo se insere na interface entre educação musical, intervenção social, neurociências e psicologia, buscando construir um campo interdisciplinar com estas disciplinas. A primeira seção deste trabalho, intitulada "Introdução", está organizada em quatro subseções encadeadas com os objetivos da pesquisa. Nas duas primeiras subseções, foram consideradas as influências do processo educativo e os impactos da música no desenvolvimento humano, buscando inter-relacionar os efeitos da música no cérebro e nas relações sociais mais amplas. A terceira subseção desenvolve a noção do uso da educação musical e seus múltiplos efeitos em aspectos comportamentais, abordando, ainda, a necessidade do desenvolvimento das metodologias que utilizam a educação musical como ferramenta de intervenção social. Por fim, na quarta subseção, são apresentados Programas de Educação Musical (PEMs) com enfoque no resgate social de crianças e adolescentes que integram populações vivendo em situação de vulnerabilidade social.

\subsection{O desenvolvimento humano e sua interface com a educação}

O desenvolvimento do pensamento abstrato foi, provavelmente, essencial para a evolução do ser humano pré-histórico. Engajar-se em pensamentos ficcionais possivelmente conferiu uma vantagem evolucionária aos nossos ancestrais. A capacidade de abstração possibilitou ganhos em diversas áreas como, por exemplo, o planejamento de ações futuras, a antecipação de eventos e a construção de ferramentas.

Luria, juntamente com Vigotski e Leontiev, é representante da abordagem históricocultural, que consiste numa tentativa da Psicologia russa do início do século XX de construir uma nova psicologia que levasse em conta o contexto sócio-histórico. Para essa abordagem, 
as Funções Psicológicas Superiores (FPS) são formadas a partir da interação da cultura com as Funções Psicológicas Elementares, de origem biológica (Vigotski, 1995). Somente através desta intermediação podem ser desenvolvidas as atividades mentais, que consistem em habilidades complexas observadas apenas na espécie humana:

"A matriz teórica histórico-cultural tem como uma de suas proposições básicas o conceito de que o ser humano se constitui devido à sua relação com os outros. As FPS desenvolvem-se quanto à sua estrutura, conteúdo e complexidade na relação que estabelecemos com as pessoas e com a cultura. Suas origens são, portanto, de natureza social e respondem, diferentemente do que ocorre em outros animais, a estímulos criados (signos), e não apenas a estímulos dados. Estas habilidades são atividades mentais internas, organizadas em sistemas funcionais, emergindo da atividade prática, desenvolvida na sociedade humana com base no trabalho, formando-se no curso da ontogênese de cada pessoa em cada nova geração."

(Veronezi, Damasceno \& Fernandes, 2005, p. 540)

Para Veronezi et al. (2005), as FPS, quais sejam, atenção, memória, imaginação, pensamento e linguagem, são arranjadas em sistemas funcionais e têm a finalidade de organizar adequadamente a vida mental de um indivíduo frente ao meio em que habita. $\mathrm{O}$ desenvolvimento das FPS, bem como o processo de aquisição das habilidades destas Funções são ramos importantes de estudos em neurociência, psicologia e educação.

$\mathrm{Na}$ tentativa de desenvolver modelos que explicassem as funções cerebrais, Luria (1984) dividiu hierarquicamente o funcionamento cerebral em três Unidades Funcionais (UF): a primeira UF é responsável pelos estados mentais, tono e vigília; a segunda UF tem a função de receber, analisar e armazenar informações; a terceira UF tem papel de programar, regular e verificar as atividades. Durante o desenvolvimento infantil, as UFs se estabelecem da mais básica para a mais complexa, ou seja, da primeira à terceira UF. Dessa forma, tem-se que quanto mais precocemente ocorrem as intercorrências no desenvolvimento infantil, maior prejuízo pode ser causado, uma vez que a primeira UF é a base para o estabelecimento das demais. A surdez é um exemplo de intercorrência que pode acometer o curso do desenvolvimento infantil acarretando prejuízos nos processos básicos. Observa-se que por se tratar de uma falha no processamento dos estímulos sonoros do ambiente, essa condição pode gerar grandes perdas em termos sociais (Purves et al., 2005). Bueno (1997) comenta que para Luria o desenvolvimento das FPS no homem é definido pela história social da humanidade, 
porém, a compreensão é incompleta se forem negligenciadas as bases biológicas desse fenômeno.

Quanto à sua anatomia, as Unidades Funcionais são formadas filogeneticamente em momentos distintos. A primeira UF é a mais antiga abrangendo o tronco cerebral e o diencéfalo, a segunda é formada pela região temporo-parieto-occipital e a terceira abrange os lobos frontais. "Todas as três Unidades Funcionais operam em concerto e mediante o estudo de suas interações, nas quais cada UF oferece sua contribuição específica própria, poder-se-á chegar a um entendimento dos mecanismos de atividade mental” (Luria, 1984, p. 84).

Para Blakemore e Frith (2005), o desenvolvimento das FPS ocorre durante toda a vida. As autoras desconstroem a noção de que quanto mais rica a estimulação ambiental nos três primeiros anos de vida mais desenvolvidas são as FPS no indivíduo adulto. Nesse sentido, Blakemore e Frith (2005) colocam em discussão a afirmação de que ambientes com grande diversidade de estímulos são ideais para o desenvolvimento da sinaptogênese, isto é, processo de formação de sinapses no Sistema Nervoso, fenômeno que ocorre com grande intensidade nos primeiros anos de vida, mas que continua a acontecer com menor intensidade durante toda a vida. Para as autoras, essa afirmação é decorrente de estudos com ratos e pouco explicativa para a espécie humana. Assim, a correta interpretação dos achados científicos seria que ambientes empobrecidos em estimulação acarretam dificuldades desenvolvimentais. Dessa maneira, destaca-se que, para Blakemore e Frith (2005), a estimulação particularmente importante, e que acarreta o desenvolvimento ideal na infância, é a interação com outros seres humanos, incluindo a linguagem e a comunicação.

A noção de que existem períodos críticos no desenvolvimento também é questionada por Blakemore e Frith (2005), uma vez que transmite uma ideia muito rígida do desenvolvimento do Sistema Nervoso, o que não corresponde ao seu real modo de funcionar. Assim, sabendo que o desenvolvimento cerebral não se encerra com o fim da maturação biológica, as autoras preferem interpretar esses momentos como períodos sensíveis de desenvolvimento. Para Lopes e Maia (2000), o termo "período crítico" traz a noção de um processo influenciado de forma irreversível, já a noção de "período sensível” é entendida como período de tempo em que o aprendizado de uma habilidade ou desenvolvimento de aptidões e competências se faz de maneira mais facilitada. Segundo os autores, os "períodos críticos" ocorrem durante o desenvolvimento embrionário, durante processos reguladores do crescimento, já os “períodos sensíveis” ocorrem durante o desenvolvimento pós-natal.

Dado este cenário, compreende-se os processos de aprendizagem constituem uma das formas de interação da cultura com as FPS, ressaltando que tal processo pode ser explicado a 
partir da noção de plasticidade cerebral, que consiste em mudanças adaptativas que ocorrem na estrutura e função do Sistema Nervoso em qualquer fase da ontogenia, como resultado de interações com o meio ambiente interno ou externo (Muszkat, 2012). Assim, a noção de plasticidade cerebral pressupõe que o cérebro está em constante desenvolvimento.

A partir desta compreensão, é importante pontuar que as pessoas não adquirem conhecimento unicamente no ambiente escolar, mas estão em constante aprendizado, a todo momento, conforme sugere Vigotsky por meio do conceito de intermediação cultural. Todavia, é importante ressaltar que é durante o processo educativo escolar que este fenômeno da intermediação cultural ocorre de maneira especial, uma vez que é nas escolas onde o aprendizado ocorre por meio de métodos especialmente desenvolvidos para potencializar o ato de aprender. Assim, o processo educacional é entendido como um momento complexo e singular para o desenvolvimento humano, devendo pautar-se em conhecimentos acadêmicos advindos dos centros de pesquisa e ensino, mas sem deixar de valorizar e apoiar-se nas realidades concretas dos estudantes e de suas comunidades (Bueno, 2012).

Segundo Immordino-Yang e Damasio (2007), o processo educacional possui conexões com elementos cognitivos, emocionais e sociais, os quais têm suporte na ativação de processos neurobiológicos. Os autores, a partir de estudos com pacientes que apresentavam danos cerebrais pré-frontais na infância e na vida adulta, mostraram que aqueles que sofreram a lesão na vida adulta conseguiram, em situação de laboratório, raciocinar logicamente e eticamente sobre questões sociais e padrões cognitivos, entretanto, fora do ambiente controlado, no mundo real, em tempo real, não conseguiram usar informações emocionais para decidir entre alternativas de ação. Dessa forma, constata-se que esses indivíduos aprenderam as regras sociais necessárias para o convívio em sociedade, mas, devido à lesão pré-frontal não conseguiram desempenhar satisfatoriamente os comportamentos corretos, muito embora tenham conhecimento dos mesmos. Por sua vez, as pessoas lesionadas na infância, aparentemente, não aprenderam a distinguir as regras de conduta social. Estes pacientes não identificaram as regras éticas e sociais que infringiram tanto no laboratório, quanto no mundo real.

De acordo com Immordino-Yang e Damasio (2007), subjacente ao aprendizado e tomada de decisões no mundo real ocorre um processamento emocional oculto. Para os autores, o que falta às pessoas com lesões pré-frontais é o "leme emocional", o qual seria responsável pelo aprendizado do comportamento social normal e também por colocá-lo em prática no mundo real. 
A partir da observação das diferenças entre indivíduos com lesão pré-frontal em situações sociais complexas, pode-se constatar a importância dos pensamentos emocionais. A biologia humana, o alto nível sociocultural e as forças cognitivas são aspectos indissociáveis que fazem do humano um ser especial no reino animal. Assim, para Immordino-Yang e Damasio (2007), quando educadores falham em prezar pela importância das emoções dos estudantes, falham em prezar pela força crítica dos estudantes no processo de aprendizagem. Dessa maneira, fica evidente a necessidade dos educadores estarem afinados com uma noção de desenvolvimento que integra aspectos psicológicos, biológicos e sociais (Bueno, 2012).

\subsection{A atividade musical e o cérebro: Impactos da música para o ser humano}

Chanda e Levitin (2013) realizaram uma ampla revisão bibliográfica sobre as funções musicais para o homem. Para os autores, a música pode ser usada com diversas funções como, por exemplo, o entretenimento, a cura e a regulação do humor e do arousal. Com função análoga a do café ou do álcool, alguns trabalhadores podem utilizar a música para melhorar a atenção e a vigilância, bem como atletas podem usá-la para aumentar os níveis de vigor e motivação. É um recurso usado, ainda, para outros fins diversos que podem variar de acordo com os hábitos culturais, buscando atribuir sentidos, significados e funções peculiares para as situações vivenciadas pelos homens, individual ou coletivamente. A música está, frequentemente, interligada com outras formas de expressão cultural, como danças, cerimônias e rituais de cura, tendo papel central em celebrações de eventos marcantes da vida: nascimento, adolescência, casamento, e morte (Swanwick, 2003). Hargreaves e North (1997), destacam que dentre as funções desempenhadas pela música na vida humana, quase todas são sociais.

Para Trehub (2003), a música promove o desenvolvimento cognitivo dos bebês e, nesse sentido, a audição musical é uma atividade complexa que tem potencial para preparar a criança para a vida mental futura como uma forma de prática da percepção (Levitin, 2008). Segundo Zampronha (2007), a música é um recurso de expressão, bem como de comunicação, gratificação, mobilização e autorrealização, atendendo a diferentes aspectos do desenvolvimento humano (físico, mental, social, emocional, espiritual).

A atividade musical está presente em toda cultura humana conhecida (Stor, 1992), sendo que os primeiros instrumentos musicais usados pelo homem são datados de cinquenta 
mil anos (Levitin, 2008). Para Chanda e Levitin (2013), a música é parte de um conjunto de aspectos universais humanos.

A biologia moderna revela que o ser humano é uma criatura fundamentalmente emocional e social (Immordino-Yang \& Damasio, 2007). Dessa forma, entende-se que o ser humano precisa de ligações sociais para fazer com que a sociedade funcione, e a música pode agir como um desses elos (Trehub, 2003; Levitin, 2008). A música abrange uma ampla gama de áreas cerebrais relacionadas à percepção de alturas, timbres e ritmos; à decodificação métrica e melódico-harmônica; à gestualidade implícita e à modulação do sistema de prazer e recompensa que acompanham as reações psíquicas e corporais (Muszkat, 2012).

Bueno (2012) examina como a experiência musical possui correlatos no corpo. Os efeitos fisiológicos da música são amplos e estão relacionados a diversos domínios que remetem a sistemas neuroquímicos específicos. O domínio da recompensa, da motivação e do prazer, cuja influência se dá pela dopamina e pelos opióides; o domínio do estresse e do arousal, influenciado pelo cortisol; o domínio da imunidade relacionado à serotonina e o domínio da afiliação social ligada à oxitocina (Chanda \& Levitin, 2013).

Peretz e Zatorre (2005) consideram que a apreciação musical, similarmente à compreensão da linguagem, parece ser o produto de uma organização cerebral específica, o que dá suporte à existência de uma rede neural músico-especifica. Mesmo que a neurociência tradicionalmente lide com a objetividade dos dados e sinais que cartografam o funcionamento cerebral, para a compreensão da experiência musical deve-se levar em conta a subjetividade, o envolvimento lúdico e a transitividade (Muszkat, 2012). Bueno (2012) cunha o termo cérebro sócio-musical para se referir à inter-relação dos diversos aspectos que compõem a experiência musical. A noção do cérebro sócio-musical proposta pelo autor aponta para a necessidade de compreensão da experiência de educação musical como geradora de desenvolvimento integrado psicológico, biológico e social. Para o autor, o funcionamento do cérebro sóciomusical se evidencia em ações de intervenção social que se utilizam de metodologias de educação musical.

\subsection{Música, educação e educação musical}

Conforme apresentado acima, muitas são as evidências de a música estar envolvida com diversos processos humanos intra e intersubjetivos. E, no que diz respeito aos processos 
de aprendizagem, existem registros na história da humanidade de situações em que a música foi associada diretamente ao ato de aprender. Para os gregos do século IV a.C., por exemplo, cada modo musical estava associado a emoções particulares (Bueno, 2012). Na construção musical, as sequências de notas escolhidas para criar determinada sonoridade são chamadas escalas. Assim, os modos gregos são sete escalas específicas sendo que cada uma se relaciona a uma região geográfica e a elementos musicológicos específicos. Tais modos são denominados Jônio, Dórico, Frígio, Lídio, Mixolídio, Eólio e Lócrio. Os modos que levavam, por exemplo, ao encorajamento e à prudência eram, respectivamente, o Frígio e o Dório (Stor, 1992). Da mesma forma, havia a compreensão de que alguns dos modos seriam ideais para o processo de aprendizagem (Bueno, 2012). Atualmente, algumas pesquisas buscam relacionar os modos musicais a emoções específicas (Ramos, Bueno \& Bigand, 2011).

Sloboda (1985) divide os estudos sobre educação musical em duas categorias: aqueles que focam na Enculturação e aqueles que focam nas Habilidades Generativas. A Enculturação se inicia assim que o sistema auditivo é formado, ou seja, três meses antes do nascimento. Ela se refere ao desenvolvimento global, o qual é caracterizado e resultante da relação entre um conjunto de capacidades primitivas e um conjunto compartilhado de experiências proporcionadas pela cultura, os quais são mediados e impactados por um sistema cognitivo em constante mudança. As Habilidades Generativas se referem a experiências específicas que não são partilhadas por todos os membros de uma mesma cultura, ocorrendo por meio da utilização de métodos de ensino em ambientes educacionais, com esforço autoconsciente, resultando em especialização.

Destaca-se que a Enculturação e as Habilidades Generativas não são necessariamente processamentos distintos e devem ser aproximados para melhor compreensão da educação musical. As Habilidades Generativas, por exemplo, dependem de um conhecimento prévio que, muitas vezes, é adquirido através da Enculturação (Bueno, 2012).

As transformações cognitivas permanentes que acompanham o processo de Enculturação e o desenvolvimento das Habilidades Generativas não ocorrem pela mera audição da música, mas, são processos complexos e que implicam na ativação de componentes cognitivos, motivacionais e emocionais, que por sua vez mobilizam estruturas sociais e neuronais (Bueno, 2012). Em crianças, há ampla evidência de que os benefícios do treino musical não se limitam à performance musical, mas também são transferidos para outros domínios auditivos e cognitivos (Hallam, 2010; Moreno et al., 2011; Rauschecker, 2005; Schellenberg, 2005). Além disso, existem evidências de que o treino musical durante a infância modifica positivamente o cérebro e alguns mecanismos comportamentais que podem 
promover robustas melhoras no sistema auditivo durante o curso da vida (Alain, Zendel, Hutka \& Bidelman, 2014).

Para Zampronha (2007), os usos e recursos da música não podem ser desprezados quando se pensa em educação, ou mesmo em saúde e bem-estar. Deste modo, a música é, dentre outros, um dos caminhos a se seguir quando se pensa em educação, desenvolvimento, crescimento e equação pessoal.

Ilari (2005) faz uma crítica sobre a relação de causalidade entre o ensino musical e prováveis benefícios extramusicais, uma vez que esta perspectiva compreende a música como um meio, uma ferramenta, e não como um recurso que possa possuir um fim em si mesmo. Segundo a autora, a música possui valor próprio e deve ter espaço nas escolas independente de possibilitar ganhos em áreas extramusicais, mas por ser uma importante forma de comunicação e de expressão humana. A música carrega traços da história, cultura e identidade social que são transmitidos através da experiência musical.

O uso da música no currículo de escolas é comum nas sociedades ocidentais. Porém, na maioria das vezes, as metodologias são baseadas no que o senso-comum ou a mídia sugerem como educativo (Bueno, 2012). É necessário que os currículos sejam pensados com base em metodologias que respondam a demandas sociais e educacionais. A música pode ser aliada à educação, ao desenvolvimento infantil e à transformação social, mas, faz-se necessário um programa estruturado e pensado a partir das necessidades identificadas nos ambientes comunitários, de maneira a responder às dificuldades, utilizando as potencialidades locais. Dessa maneira, essa perspectiva aponta para uma noção de educação musical que não pode prescindir de levar em conta os múltiplos componentes da experiência musical.

\subsection{Programas de Educação Musical com enfoque em intervenção social e seus impactos no desenvolvimento humano}

Tem-se podido observar nos dias atuais o desenvolvimento de diversas iniciativas cujo enfoque é o resgate de populações em vulnerabilidade social. Empresas, governos e cidadãos têm gastado recursos, energia e tempo organizando projetos com o objetivo de intervir socialmente com as populações classificadas como vulneráveis. Os métodos de ação se valem de diversos recursos como o esporte, as artes, o treinamento de habilidades específicas, os cursos extracurriculares, entre outros. Neste cenário, a música se destaca como um desses 
métodos e sua utilização enquanto recurso para intervenção social será contextualizado na sequência.

\subsection{1. "El Sistema"}

O "El Sistema” é um Programa de Educação Musical (PEM) com foco em intervenção social, desenvolvido na Venezuela a partir de 1975 pelo Maestro José Antônio Abreu, ficando conhecido mundialmente pela natureza inovadora de sua proposta e pelos resultados alcançados.

A Orquestra Sinfônica Nacional da Venezuela, fundada em 1930, funcionou até 1975 unicamente com a participação de músicos estrangeiros. Naquela época, o estudo da música clássica era restrito a camadas mais abastadas da população venezuelana. Foi neste contexto que José Antônio Abreu se tornou músico, conseguindo realizar sua grande aspiração. Maestro e economista, Abreu desejava que a oportunidade de ser músico fosse oferecida a todos os jovens venezuelanos, tornando, assim, "a música uma realidade profunda e global" (Abreu, 2009). Em 1975, ganhou 50 estantes de partituras para serem usadas por 100 estudantes. No primeiro ensaio, ocorrido em uma garagem, compareceram 11 crianças, o que o levou ao questionamento “acabo com esse programa ou multiplico esse número?" (Abreu, 2009).

José Antônio Abreu, também educador e ativista político, continuou lecionando e inspirando estudantes e professores que foram se juntando a ele e a seu projeto de transformação social e de educação musical. Quarenta anos depois, a "Fundación del Estado para el Sistema Nacional de las Orquestas Juveniles e Infantiles de Venezuela" (FESNOJIV), recentemente nomeada de "Fundácion Musical Simón Bolívar" (FundaMusical), ou simplesmente "El Sistema", conta com 423 Núcleos espalhados por todos os estados venezuelanos. A estrutura funcional, educativa, artística e administrativa que dá forma ao "El Sistema" é chamada "Núcleo". Tais Núcleos podem variar em tamanho e complexidade, a depender do contexto.

Atualmente, o "El Sistema" inclui mais de 700.000 estudantes, em sua maioria de extratos sociais com baixos recursos econômicos. Estes estudantes são divididos em 285 orquestras pré-infantis (4 a 6 anos), 220 orquestras infantis (7 a 16 anos), 180 orquestras juvenis (16 a 22 anos). O programa conta, ainda, com 30 orquestras profissionais, 360 coros, 
1355 coros filiados, 20 oficinas de luteria e 9010 professores distribuídos pelos 24 estados venezuelanos (Fundácion Musical Simón Bolívar [FundaMusical], s.d.)

Adaptações do modelo do "El Sistema" estão sendo implantadas em diversas partes do mundo. Atualmente, no website da FundaMusical estão registrados mais de 40 países, dentre eles o Brasil, com iniciativas que seguem o modelo venezuelano (FundaMusical, s.d.).

Creech, Gonzalez-Moreno e Waitman (2013) realizaram uma ampla revisão de estudos sobre PEMs baseados no modelo do "El Sistema" e encontraram diversos efeitos destes programas nas habilidades dos estudantes. Os autores organizam essas habilidades em dois grandes grupos denominados "desenvolvimento pessoal" e "habilidades sociais". O primeiro grupo apresentou 32 construtos diferentes, dentre eles são citados: comprometimento, determinação, disciplina, bem-estar emocional, satisfação com a vida, motivação, atitudes positivas em relação à escola, responsabilidade e autoestima. O segundo grupo se refere a 16 diferentes construtos, dentre eles: cooperação, aprendizado colaborativo, integração grupal, comportamento pró-social, solidariedade e trabalho em equipe. Os PEMs baseados no modelo do "El Sistema" começaram a ser implantados na década de 70, porém mais de 50\% dos PEMs foram criados após 2006 e 34\% após 2010 o que indica que, na ocasião da revisão um número significativo estava em atividade há pouco tempo, alguns há menos de 3 anos, o que pode ter dificultado a identificação de impactos mais amplos.

Para Allan (2010) intervir em comunidade através das artes em geral tem o objetivo de ser uma via de acesso a algo novo, belo e transformador, possuindo o potencial de desafiar práticas de exclusão. Segundo Abreu (2009), o "El Sistema” é um programa de resgate social e de profunda transformação cultural, elaborado para toda a sociedade venezuelana sem qualquer distinção, mas, com ênfase nos grupos sociais mais vulneráveis e ameaçados. Para o "El Sistema", a pobreza material e a psicológica não são equivalentes (Slevin \& Slevin, 2013).

Alguns autores estruturaram as principais características que permitiram ao "El Sistema" atingir suas metas e se tornar referência mundial no ensino coletivo de música. Segundo Govias (2011), os cinco fundamentos do "El Sistema" são: mudança social, prática conjunta, frequência, acessibilidade e conectividade. Majno (2012), sintetiza os princípios metodológicos do "El Sistema" em cinco categorias, a saber: acessibilidade (critérios de admissão não seletivos e não elitistas), regularidade e intensidade de treinamento, cursos coletivos (prática conjunta), busca da qualidade artística e reconhecimento da excelência.

Booth (2013) organizou um guia que aborda aspectos importantes para orientar programas inspirados no "El Sistema". Para ele, os elementos fundamentais são: 1) a missão 
de transformação social; 2) o acesso e a excelência; 3) o ambiente de cada Núcleo; 4) a intensidade da prática musical; 5) o ensino em grupo; 6) o modelo CAPE (CATS em inglês), no qual cada trabalhador do Núcleo age como Cidadão, Artista, Professor (Teacher) e Estudante (Scholar); 7) a continuidade durante os anos; 8) a inclusão familiar e comunitária; 9) as conexões e o trabalho em rede entre os Núcleos; 10) a ambição e a realização.

Para Booth (2013), os muros dos Núcleos são membranas porosas que permitem um fluxo constante de trocas entre os recursos internos e comunitários. No "El Sistema", a partir do nível juvenil é fornecida uma bolsa de estudos, que consiste num fator de motivação para estudantes e seus pais, pois trata-se de uma quantia considerável que pode variar de 100 a 500 dólares, e, em alguns casos, integra a renda familiar (Uy, 2012). A bolsa, ainda, atribui valor real ao fazer musical perante as famílias e a comunidade (Booth, 2009). Para receber a bolsa, o estudante deve, além dos ensaios e apresentações que já realizava, despender algumas horas com atividades extras no Núcleo como, por exemplo, ensinar estudantes mais novos.

Segundo Abreu (2009), o impacto do "El Sistema" pode ser sentido em três esferas fundamentais: pessoal/social, familiar e comunitária. Na esfera pessoal/social há o desenvolvimento intelectual e emocional das crianças por meio do desenvolvimento da capacidade de liderança e da possibilidade de contribuição individual para o alcance de objetivos coletivos maiores, contribuindo para a autoestima e a confiança e ainda aponta ganhos intelectuais relacionados às habilidades cognitivas. Na esfera familiar observa-se a possibilidade de estreitamento dos laços familiares, uma vez que a própria organização dos Núcleos favorece a participação dos pais no Programa. Na esfera comunitária tem-se que as orquestras constituem espaços culturais criativos e fontes de trocas e de construção de novos significados, contribuindo para a consolidação de uma noção de comunidade. Nesta perspectiva, a música deixa de ser um item de luxo e passa a ser um patrimônio da sociedade.

As três esferas não são mutuamente excludentes, de forma que o impacto individual também impacta família e comunidade, que por sua vez dão o suporte necessário ao nível pessoal. A participação dos pais é uma atividade programática crucial, pois entende-se que compete a eles colaborar nas atividades dos filhos, participar dos concertos, cuidar dos materiais necessários para aprendizagem musical, estar atentos às tarefas dos filhos, informar os coordenadores quando os filhos não atendem às demandas da sala de aula, e ainda, assumir financeiramente qualquer dano causado pelo filho às instalações ou aos instrumentos. Além disso, em muitos Núcleos existem as "Sociedades de Pais e Representantes" que surgiram a partir da iniciativa e desejo dos próprios pais de contribuírem para a orquestra (Uy, 2012). 
De acordo com Abreu (2009) e com os apontamentos feitos por Creech et al. (2013) sobre PEMs ao redor do mundo baseados na metodologia do "El Sistema", infere-se que os efeitos mais relevantes do envolvimento com esta metodologia estão associados à autoestima, às habilidades sociais e ao funcionamento executivo. Desta maneira, será apresentada a seguir uma breve descrição desses impactos, bem como sua relação com circuitos cerebrais envolvidos em seu processamento.

\section{a) Autoestima}

A autoestima pode ser entendida como um conjunto de sentimentos e pensamentos do indivíduo sobre seu próprio valor, competência e adequação, que se reflete em uma atitude positiva ou negativa em com relação a si mesmo (Rosenberg, 1965). Dessa maneira, segundo Gonçalves e Neto (2013) a importância que os estudos atribuem a autoestima reside em sua influência determinante e decisiva no comportamento psicológico dos indivíduos. Alto nível de autoestima é um preditor de saúde mental e bem estar (Baumeister, Campbell, Krueger \& Vohs, 2003; Freire \& Tavares, 2011) e está correlacionado ao desempenho acadêmico. Entretanto, conforme destaca Baumeister et al. (2003), a autoestima elevada não acarreta melhor desempenho, mas, ao contrário, é o bom desempenho acadêmico que aumenta o nível de autoestima do indivíduo.

Em nível do processamento neurológico, a autoestima faz parte do processamento auto referencial (Northoff et al., 2006). Tal processamento ocorre em áreas terciárias do cérebro, a saber, córtex pré-frontal medial (ventral e dorsal), giro do cíngulo (anterior e posterior), precuneos e córtex temporoparietal (Frewen, Lundberg, Brimson-Théberge \& Théberge, 2013).

No modelo metodológico do "El Sistema", a busca pela excelência musical (Abreu, 2009) se relaciona com a noção de Baumeister et al. (2003) sobre o desenvolvimento da autoestima. Destaca-se que Creech et al. (2013) encontraram efeitos positivos na autoestima dos estudantes de PEMs baseados no modelo do "El Sistema". Assim, hipotetiza-se que o aumento das capacidades de desempenhar uma tarefa com excelência, o que no caso do "El Sistema" está relacionado a tocar um instrumento em conjunto, tem efeitos positivos na autoestima dos estudantes. 


\section{b) Habilidades Sociais}

As habilidades sociais podem ser definidas como o padrão completo de comportamento mostrado por um indivíduo durante uma relação interpessoal (Teodoro et al., 2005). Desta maneira, não se limitam a um único fator ou a uma habilidade específica, sendo um construto que envolve características individuais e fatores contextuais (Del Prette \& Del Prette, 1999). Baixos níveis de habilidades sociais estão associados ao comportamento agressivo que, por sua vez, é um preditor de envolvimento criminal futuro (Schaeffer, Petras, Ialongo, Poduska, \& Kellam, 2003).

Segundo Butman e Allegri (2001), baseados em estudos experimentais com animais e com pacientes com lesão cerebral, as estruturas anatômicas associadas aos processos cognitivos superiores, responsáveis por sustentarem as condutas sociais, são a amigdala, o córtex pré frontalventromedial, a ínsula e o córtex somatosensorial direito.

O desenvolvimento de ambientes socialmente saudáveis pode ter efeitos positivos no relacionamento interpessoal. Segundo Creech et al. (2013), PEMs baseados no modelo do "El Sistema" atribuem valor fundamental a alguns elementos que se relacionam diretamente ao desenvolvimento de habilidades sociais, por exemplo, a constituição de um ambiente seguro à aprendizagem e o estabelecimento de relacionamentos interpessoais positivos entre professores e alunos. Diversos estudos revisados por Creech et al. (2013) encontraram efeitos positivos em habilidades sociais dos estudantes. Destaca-se que todos os estudos referidos pelos autores realizaram entrevistas com pais e professores para chegarem a essa conclusão (Creech et al., 2013). Com base em tais achados, observou-se a necessidade de realização de estudos que, por meio do uso de escalas e testes, efetuem a mensuração dos fatores com precisão quantitativa.

\section{c) Funcionamento executivo}

Os comportamentos complexos, tais como programar, regular e verificar atividades, estão ligados aos aspectos da vida consciente, ao funcionamento executivo e às regiões cerebrais mais anteriores (Luria, 1984). Assim, as habilidades cognitivas, apontadas por Abreu (2009) como efeitos da participação dos estudantes no "El Sistema", são compreendidas como componentes do funcionamento executivo. $\mathrm{O}$ desenvolvimento dessas habilidades é crucial para o bem-estar mental do adulto, visto que são importantes para uma vida bem sucedida e adaptada (Barros \& Hazin, 2013). 
Em revisão feita por Jurado e Rosselli (2007), os autores encontraram que a hipótese de que o córtex pré-frontal possui um papel crítico no funcionamento executivo tem sido aceita pela maioria dos pesquisadores. Entretanto, outras áreas cerebrais, como as regiões subcorticais e o córtex posterior, estão envolvidas na integração de informações e na regulação de emoções, pensamentos e ações.

Todas essas as regiões cerebrais identificadas como sendo centros responsáveis por organizar as informações relacionadas à autoestima, habilidades sociais e cognitivas se referem à terceira UF (Luria, 1984). Esta UF é responsável por organizar, programar, regular e verificar atividades, sendo que estas ações envolvem grande número de processamentos cerebrais inferiores, indicando a inter-relação entre as três UFs proposta por Luria (1984).

Uy (2012) utiliza o conceito de práxis de Paulo Freire para apontar que é através da possibilidade de engajar-se na realidade do Programa que estudantes, pais e professores conseguem encontrar caminhos para refletir e agir criticamente sobre o contexto. Para Feire (1987) a práxis “é reflexão e ação dos homens sobre o mundo para transformá-lo" (p. 21). Esta perspectiva de Freire levantada por Uy (2012) para descrever o engajamento dos pais na organização do "El Sistema" também ajuda a entender o desenvolvimento do próprio "El Sistema". Desde o princípio, Abreu e seus colegas não partiram de conhecimentos acumulados pela academia de como deveria ser a intervenção social usando a música como método de intervenção. Ao invés disso, buscaram desenvolver uma estrutura na qual a intervenção social se conformasse a partir das necessidades concretas das comunidades venezuelanas, com o objetivo de formar pessoas através do ensino musical. O método do "El Sistema" foi sendo construído à medida em que o PEM se desenvolvia. O conhecimento musical de Abreu e seus colegas se somava e se adaptava aos conhecimentos das comunidades em que o "El Sistema" estava inserido e, complementarmente, tais comunidades se adaptavam e somavam ao "El Sistema". Para Bueno (2012), a música produz efeitos ambientais e é pelo ambiente influenciada.

Para Allan (2010), pesquisadora do "Sistema Scotland", versão escocesa do "El Sistema", há um crescente número de projetos artísticos que visam à transformação social. Para Majno (2012), existe a necessidade de reunir mais evidências e de apontar mais provas em termos de benefícios cognitivos e melhorias sociais que justifiquem o investimento em larga escala em projetos com esse objetivo. Existem algumas iniciativas de pesquisas do efeito do "El Sistema" e de outros programas de intervenção social através da música ou da 
arte (Allan, 2010; Allan, Moran, Duffy \& Loening, 2010; Hikiji, 2005; 2006a; 2006b; Majno, 2012; Uy, 2012; Associação Amigos do projeto Guri [AAPG] \& Ipsus, 2013), mas ainda é necessário um esforço coordenado para alcançar uma massa crítica de resultados. Programas como o "El Sistema" devem ser objeto de estudo de ambientes acadêmicos avançados, além disso, é preciso aperfeiçoar a disponibilização de informações, a acessibilidade de materiais, a troca de experiências e a oferta de oportunidades de treinamento (Majno, 2012). Allan (2010) ressalta, ainda, que devem ser evitadas vinculações banais e causais entre a intervenção e estados ontológicos como "transformação" e "empoderamento". Neste cenário, torna-se relevante investigar o processo pelo qual passam os indivíduos que vivenciam o Programa, entendendo tais indivíduos como os estudantes, pais, técnicos e profissionais, bem como o território em que se dá a intervenção.

Infere-se que os resultados de estudos com tais objetivos podem evidenciar os elementos que desencadeiam o desenvolvimento humano almejados pelos Programas que utilizam a educação musical como meio de intervenção social. Tais pesquisas podem, ainda, contribuir para o aperfeiçoamento das metodologias musicais utilizadas nesses contextos.

No que diz respeito à implementação de PEMs que compartilham dos objetivos e valores do "El Sistema", Allan et al. (2010) apontam para a importância deste processo se dar através de "trocas de conhecimentos" entre o modelo, o conhecimento técnico e os saberes da população. Os modelos implementados pelo mundo e baseados no "El Sistema" não são cópias do original, mas versões transformadas e adaptadas às necessidades, demandas e potencialidades de cada localidade. E, sendo assim, tais singularidades devem ser incluídas nas discussões dos impactos que advém dos Programas. Nesse sentido, considera-se que a psicologia tem papel fundamental em desenvolver testes de habilidades que indiquem musicalidade (Bueno, 2012) e, além disso, auxiliar no desenvolvimento de indicadores dos efeitos que estes Programas geram em comunidades e em indivíduos.

Levando em consideração o contexto brasileiro, constatou-se que existem diversos PEMs com o enfoque no resgate social que compartilham com o "El Sistema" os princípios, a missão e os objetivos de formar pessoas através do ensino musical coletivo. Estes PEMs estão listados no website do "El Sistema", sendo eles: Projeto Guri, Organização Não Governamental (ONG) Orquestrando a Vida, Núcleos Estaduais de Orquestras Juvenis e Infantis da Bahia (NEOJIBA), Instituto Baccarelli e Cidadão Musical (FundaMusical, s.d.). Nem todos estes PEMs nasceram vinculados ao "El Sistema", mas hoje todos têm algum tipo de conexão com ele, formando uma rede mundial de PEMs com enfoque no desenvolvimento humano através do ensino coletivo de música. 
O PEM brasileiro selecionado para realização desta pesquisa é o Projeto Guri (Anexo 1), que será apresentado na sequência com destaque para seu processo histórico de criação e aperfeiçoamento da proposta, bem como para aspectos estruturais de seu funcionamento. Ressalta-se que a criação do Projeto Guri não se deu vinculada ao "El Sistema", mas parte de uma iniciativa do governo do Estado de São Paulo, por meio da Secretaria de Cultura, com o propósito de resgatar crianças e adolescentes em situação de vulnerabilidade social. Destacase que a aproximação dos dois PEMs se deu nos últimos anos e apenas em meados de 2015 o Projeto Guri passou a constar no website do "El Sistema" como Programa parceiro.

\subsubsection{Projeto Guri}

Criado em 1995 na cidade de São Paulo na Oficina Mazzaropi, hoje Polo Amácio Mazzaropi, o Projeto Guri é um PEM que oferece cursos de canto coral, luteria, instrumentos de cordas dedilhadas, cordas friccionadas, sopro, teclados, percussão e iniciação musical, a crianças e adolescentes entre 6 e 18 anos. As aulas acontecem nos períodos de contra turno escolar visando favorecer a participação dos alunos sem comprometimento das atividades escolares regulares. Praticamente desde sua criação o Projeto Guri está inserido na Fundação Casa, antiga Fundação Estadual do Bem Estar do Menor (FEBEM), tendo sido implantado primeiro Polo em 1996 no Complexo do Tatuapé (Associação Amigos do Projeto Guri [AAPG], 2015).

A Associação Amigos do Projeto Guri (AAPG), responsável por administrar os Polos do Projeto Guri do interior, do litoral e da Fundação Casa é dividida em três Diretorias ligadas à Direção Executiva estadual, sendo elas: Diretoria Educacional, Diretoria Administrativo Financeira e Diretoria de Desenvolvimento Social. Já os Polos da capital são administrados pela Organização Social Santa Marcelina Cultura. No que diz respeito ao financiamento, temse que o Governo do Estado de São Paulo foi o idealizador e hoje é o principal mantenedor do Projeto Guri. Além do governo do Estado, a AAPG conta com o apoio financeiro de prefeituras, empresas, Organizações Sociais e pessoas físicas (Associação Amigos do Projeto Guri [AAPG], 2014).

Vale ressaltar que o Projeto Guri configura-se como o Projeto Sociocultural brasileiro de maior abrangência (AAPG, 2015). Atualmente, o Projeto Guri dispõe de 410 Polos distribuídos por todo o Estado de São Paulo, atendendo a 47 mil crianças e adolescentes. No 
ano de 2014, quando o Projeto completou 19 anos de existência, 550 mil crianças e adolescentes já haviam passado por ele.

São chamadas de "Polos" as unidades básicas do Projeto Guri, onde acontecem as aulas de música, as quais são entendidas como a atividade fim do Projeto, ou seja, o que dá sentido à sua existência. Hierarquicamente, acima dos Polos estão as Regionais Administrativas que foram criadas em 2008 como consequência de um processo de interiorização do Projeto ocorrido em 2006, ano em que o número de Polos aumentou de 100 para 300, intensificando a necessidade de melhor gerenciar as unidades recém-abertas. Acima das Regionais Administrativas está a Sede que gerencia todo o Projeto e determina as metas que devem pautar as atividades dos Polos e das Regionais. Assim, a AAPG é dividida em 1 Sede localizada na cidade de São Paulo, 12 Regionais Administrativas e 370 Polos distribuídos por todo Estado de São Paulo. (Figuras 1 e 2).

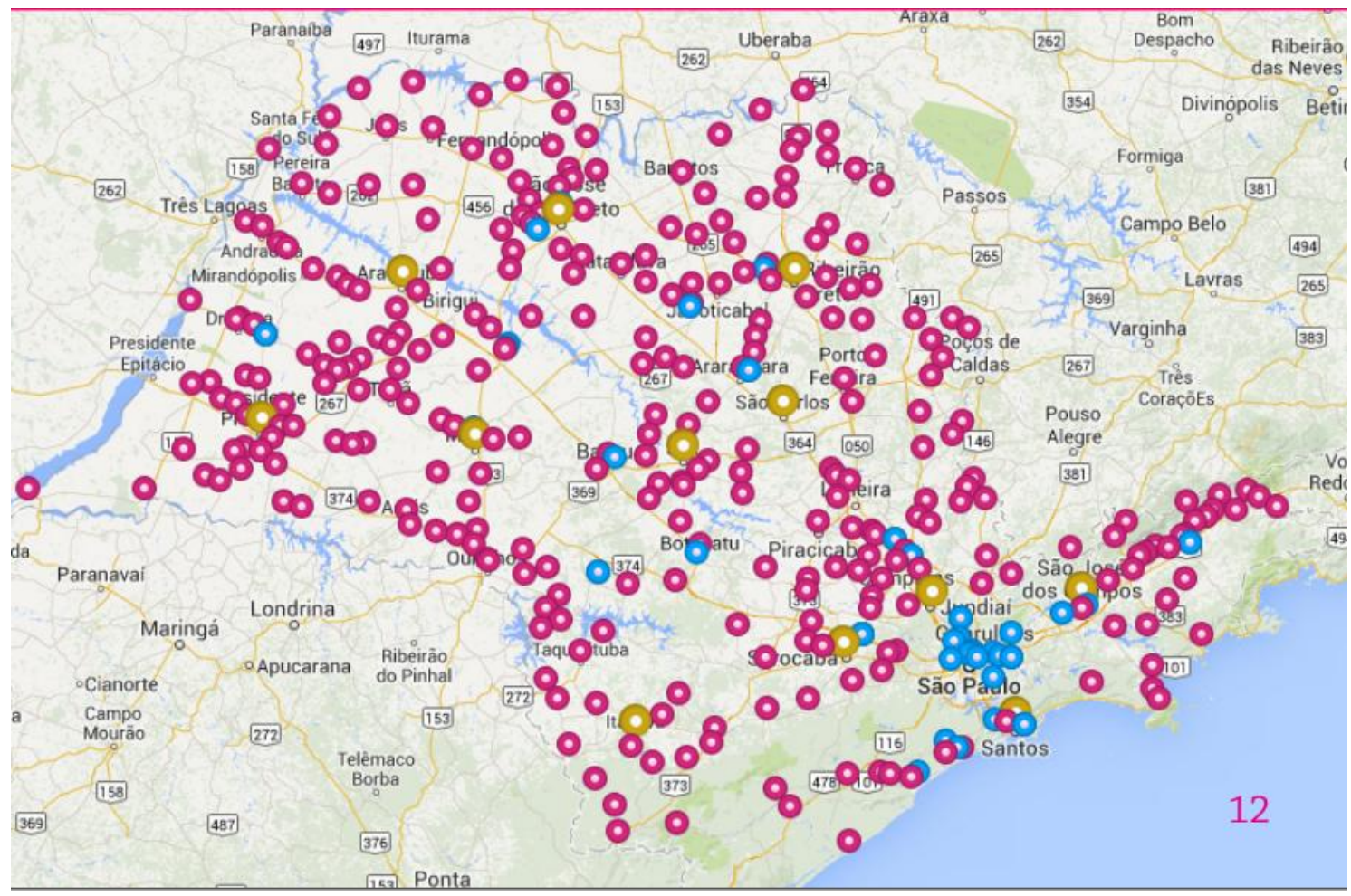

Figura 1. Distribuição dos Polos (०), Polos em Fundação Casa (†) e Regionais Administrativas (○) do Projeto Guri em todo o Estado de São Paulo. 


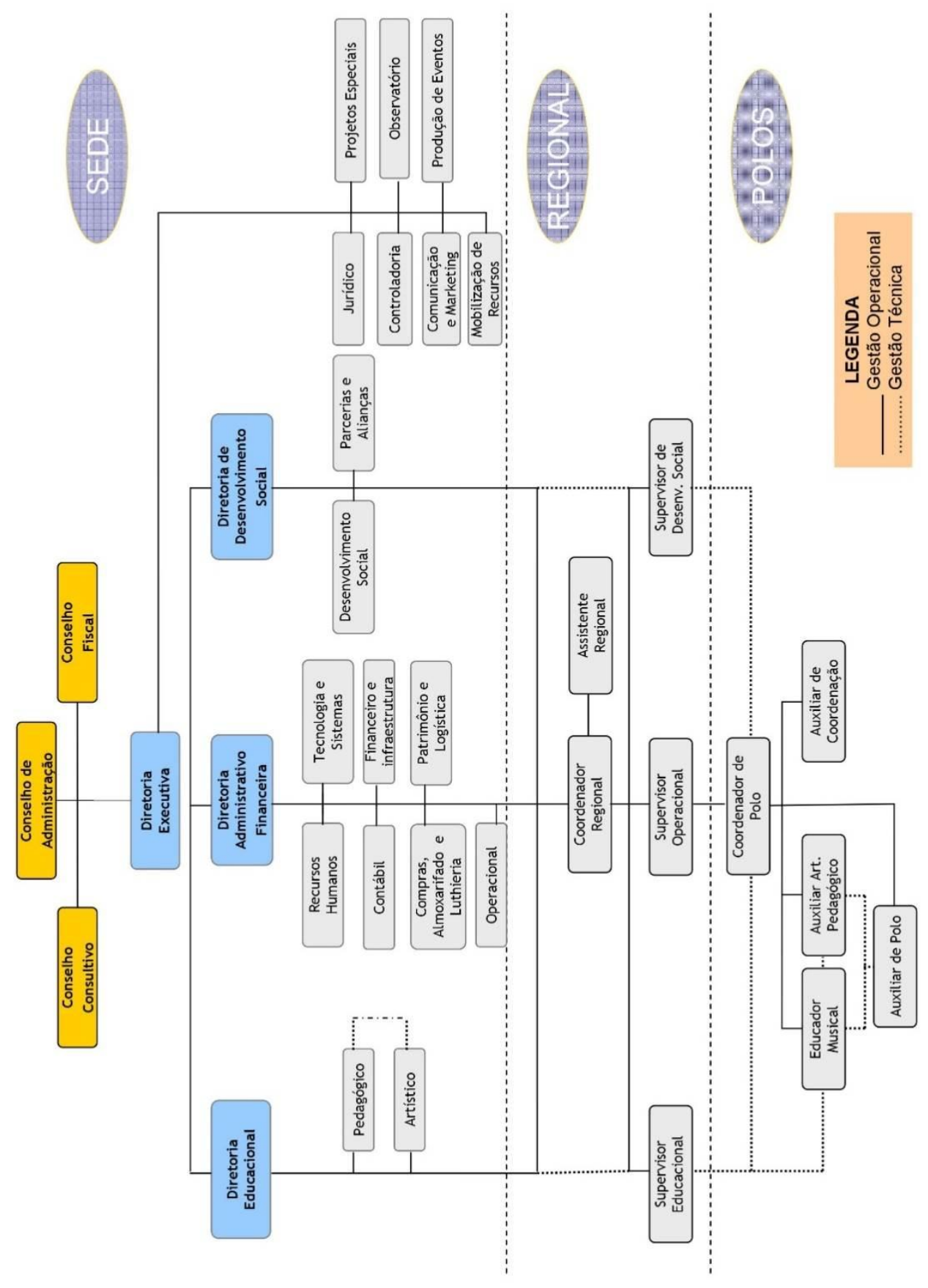

Figura 2. Organograma funcional sintético da Associação Amigos do Projeto Guri identificando os três níveis administrativos: Sede, Regional e Polo.

Segundo o website do Projeto Guri, sua missão é promover, com excelência, a educação musical e a prática coletiva da música, tendo em vista o desenvolvimento humano 
de gerações em formação. Os principais objetivos da Associação Amigos do Projeto Guri são fortalecer a formação das crianças, adolescentes e jovens como sujeitos integrados positivamente em sociedade e difundir a cultura musical em sua diversidade. Desta maneira as ações de seus programas e projetos:

“(...) propõem às crianças, adolescentes e jovens a potencialização de suas dimensões estética, afetiva, cognitiva, motora e social, a garantia de vivências enriquecedoras de sociabilidade, o fortalecimento no reconhecimento de seus recursos - que possam ser acionados em projetos de futuro -, o acesso e valorização das diferentes expressões culturais e o estímulo a criações e apresentações de grupos musicais".

(AAPG, 2014)

O acesso ao Projeto Guri é universal e gratuito, porém existem políticas internas com foco na atração, inclusão e manutenção de alunos em situação de vulnerabilidade econômica e social (AAPG, 2014).

Cada Polo adéqua sua rotina de atividades de acordo com a realidade local. Por exemplo, a depender de como são formadas as parcerias municipais, alguns Polos podem fornecer transporte para os estudantes e/ou lanche entre as aulas. Além disso, também varia o tempo de funcionamento de cada Polo, que pode chegar a apenas dois períodos na semana em algumas cidades pequenas. Apesar dessa variação entre um Polo e outro, há uma estrutura mínima para que uma nova unidade seja aberta e mantida e, nesse contexto, cabe à Regional Administrativa fiscalizar os Polos recém abertos e avaliar os projetos de novos Polos, negociando parcerias e certificando o cumprimento das exigências para o funcionamento adequado.

Em cada Polo existem três tipos de turmas (A, B e C), que dividem os estudantes de acordo com as habilidades musicais que possuem. As turmas "A" incluem os alunos com menos experiência, que vão evoluindo até integrarem as turmas "C". Ressalta-se que as turmas “C” são as únicas que realizam apresentações artísticas, sendo que as demais se apresentam unicamente nas apresentações pedagógicas ao final de cada semestre.

Cada instrumento exige uma idade mínima para que se possa ingressar nas aulas. No caso do violino, por exemplo, a idade mínima é nove anos, já o contrabaixo é doze anos. Ao entrar no Projeto com idade entre seis e oito anos o aluno participa das aulas de Iniciação Musical e apenas a partir dos oito anos pode se inserir nas turmas para aprendizado de algum instrumento. 
Os estudos envolvendo o Projeto Guri são poucos. Na base de dados "Web of Science" quando utilizado o descritor "Projeto Guri" apenas dois artigos são encontrados, ambos da mesma autora, Rose Hikiji, que em seu doutorado estudou o Projeto Guri em um Polo da FEBEM, atual Fundação Casa, e discutiu os efeitos observados nos estudantes durante as apresentações públicas, denominadas performances. Os artigos de Hikiji (2005; 2006a) são derivados de sua tese realizada utilizando o método etnográfico de pesquisa (Hikiji, 2006b). Durante o período de seu doutorado a autora também produziu curtas metragens com os internos da FEBEM Hikiji, 2003a; 2003b).

Para Hikiji (2006b) o Projeto Guri possibilita que os adolescentes internos da FEBEM vivam algo distinto do comum. A autora observou que durante as aulas de música, eles se tornavam "guris" e perdiam o estigma de internos. Nas apresentações, no momento da performance, uma outra identidade podia ser construída. As aulas, que eram escolhidas pelos adolescentes frequentemente para "matar o tempo", fizeram com que vivenciassem uma outra forma de se verem. Eram raras as possibilidades que os adolescentes possuíam de, durante o período de cumprimento da medida socioeducativa, participar de atividades externas à FEBEM. Nesse sentido, as aulas de música possibilitaram não só que estas atividades ocorressem, mas, mais do que isso, oportunizaram que os adolescentes se apresentassem em palcos de teatros consagrados da música erudita.

Segundo a autora, a teoria da antropologia da performance ajuda a analisar o fenômeno da relação entre prática musical e intervenção social. A performance pode ser entendida como "finalização de uma experiência" (Hikiji, 2005). Na e para a performance ocorre a exibição da identidade e a construção de auto-imagens. Visto que auto-imagem não é um conceito fixo e imutável, mas dinâmico e relacional, tem-se que a performance também pode ser entendida como espaço de transformação (Hikiji, 2005), transformação esta almejada pelos PEMs em geral. 



\section{Justificativa}

A atividade musical envolve aspectos cognitivos, emocionais, motivacionais e sociais, tendo suporte na ativação de processos neurobiológicos (Bueno, 2012; Immordino-Yang \& Damasio, 2007). Devido a essas características, a apreciação musical parece ser o produto de uma organização cerebral específica, o que dá suporte à existência de uma rede neural músico-especifica (Peretz \& Zatorre, 2005).

Bueno (2012) cunha o termo cérebro sócio-musical para se referir à inter-relação dos diversos aspectos que compõem a experiência musical. A noção do cérebro sócio-musical proposta pelo autor aponta para a necessidade de compreensão da experiência de educação musical como algo que gera desenvolvimento humano, implicando e integrando aspectos psicológicos, biológicos e sociais. Para o autor, o funcionamento do cérebro sócio-musical se evidencia em ações de intervenção social que se utilizam de metodologias de educação musical.

O uso da música no currículo de escolas é comum nas sociedades ocidentais, porém, na maioria das vezes, as metodologias são baseadas no que o senso-comum ou a mídia sugerem como educativo (Bueno, 2012). É necessário que os currículos sejam pensados com base em metodologias que respondam a demandas sociais e educacionais. A música pode ser aliada à educação, ao desenvolvimento infantil e à transformação social, mas, faz-se necessário o uso de programas estruturados e pensados a partir das necessidades identificadas nos ambientes comunitários, de maneira a responder às dificuldades destes locais, utilizando suas potencialidades. Dessa maneira, essa perspectiva aponta para uma noção de educação musical que não pode prescindir de levar em conta os múltiplos componentes da experiência musical.

Em crianças, há ampla evidência de que os benefícios do treino musical não se limitam à performance musical, mas, também, são transferidos para outros domínios auditivos e cognitivos (Hallam, 2010; Moreno et al., 2011; Rauschecker, 2005; Schellenberg, 2005; Trehub, 2003). Além disso, existem evidências de que o treino musical durante a infância modifica positivamente o cérebro e mecanismos comportamentais promovendo robustas melhoras no sistema auditivo durante o curso da vida (Alain et al., 2014).

Os estudos sobre os efeitos do treino musical na plasticidade cerebral colocam em evidência o potencial da utilização da música como auxiliar no processo desenvolvimental de crianças e adolescentes. Para Allan (2010) e Majno (2012), a arte tem o potencial de desafiar 
as práticas de exclusão e, nesta lógica, Programas de Educação Musical (PEMs) podem trazer ganhos diversos aos seus envolvidos, uma vez que utilizam a música como forma de resgate social de crianças e adolescente em situação de vulnerabilidade social. Além disso, é importante ressaltar que a partir da revisão para a realização desta pesquisa não foram encontrados estudos que abordassem a inter-relação entre o desenvolvimento de aspectos psicossociais e biológicos em PEMs.

O PEM "El Sistema", criado em 1975 pelo maestro e economista José Antônio Abreu, é um Programa de resgate social e de profunda transformação cultural elaborado para toda a sociedade venezuelana sem quaisquer distinções, mas com ênfase nos grupos sociais mais vulneráveis e ameaçados (Abreu, 2009). O sucesso no cumprimento do objetivo de resgate social baseia-se numa intervenção que atua em três esferas: pessoal/social, familiar e comunitária. Atualmente, na Venezuela, existem mais de 400.000 estudantes matriculados no "El Sistema” (FundaMusical, s.d.). Muitos países do mundo possuem Programas vinculados ao venezuelano, dentre eles: EUA (Cline, 2012) Brasil (Poloni, 2012) e Reino Unido (Uy, 2012). Em ampla revisão de estudos e PEMs baseados no modelo do "El Sistema" ao redor do mundo, Creech et al. (2013) encontraram diversos efeitos destes PEMs nas habilidades dos estudantes.

Hikiji (2006b) em estudo sobre o Projeto Guri, PEM do Estado de São Paulo que também tem como foco o resgate social de crianças e adolescentes em situação de vulnerabilidade social (AAPG, 2014), discute os impactos da performance nos estudantes. Programas como o Projeto Guri e o "El Sistema" promovem apresentações dos estudantes desde os primeiros meses de participação nas aulas. Para a autora, a performance dá visibilidade aos estudantes e à instituição, além de oportunizar aos "performers" a possibilidade de experimentarem novos locais sociais.

A imersão e a prática conjunta de música orquestral promovida pelo "El Sistema" geram resultados que perpassam as três esferas de intervenção, culminando na excelência musical dos músicos do Programa (Abreu, 2009). Destaca-se que a família dos alunos e as comunidades do entorno do PEM também são afetadas pelo mesmo, uma vez que a participação destas instâncias no cotidiano do Programa é tida como pré-requisito básico.

A literatura aponta a existência de correlações positivas entre autoestima e habilidades sociais (Rubin et al., 2004) e ainda, indica o desenvolvimento de ganhos cognitivos a partir do envolvimento com educação musical (Schellenberg, 2005; 2006). Abreu (2009) identifica o desenvolvimento da autoestima, das habilidades sociais e do funcionamento executivo como relevantes impactos do "El Sistema" na esfera pessoal/social. 
A autoestima pode ser entendida como um conjunto de sentimentos e pensamentos do indivíduo sobre seu próprio valor, competência e adequação, que se reflete em uma atitude positiva ou negativa em relação a si mesmo (Rosenberg, 1965). Dessa maneira, segundo Gonçalves e Neto (2013) a importância que os estudos dão a autoestima reside em sua influência determinante e decisiva no comportamento psicológico dos indivíduos. Alto nível de autoestima é um preditor de saúde mental e bem-estar (Baumeister et al., 2003; Freire \& Tavares, 2011) e está correlacionado ao desempenho acadêmico. Entretanto, conforme destaca Baumeister et al. (2003), a autoestima elevada não acarreta melhor desempenho, mas, ao contrário, é o bom desempenho acadêmico que aumenta o nível de autoestima do indivíduo.

As habilidades sociais podem ser definidas como o padrão completo de comportamento mostrado por um indivíduo durante uma relação interpessoal (Teodoro et al., 2005). Baixos níveis de habilidades sociais estão associados ao comportamento agressivo que, por sua vez, é um preditor de envolvimento criminal futuro (Schaeffer et al., 2003).

As habilidades cognitivas se relacionam a comportamentos complexos como programar, regular e verificar atividades, que estão ligados aos aspectos da vida consciente, ao funcionamento executivo e às regiões cerebrais mais anteriores (Luria, 1984). Assim, as capacidades intelectuais de concentração, flexibilidade mental e autorregulação, apontadas por Abreu (2009) como efeitos da participação dos estudantes no "El Sistema" são componentes do funcionamento executivo. O desenvolvimento dessas habilidades é crucial para o bem-estar mental do adulto, visto que são importantes para uma vida bem sucedida e adaptada (Barros \& Hazin, 2013).

Portanto, justifica-se a necessidade apontada por Bueno (2012) e Majno (2012) de realização de estudos científicos que tenham como objetivo verificar impactos das intervenções propostas pelos Programas de Educação Musical sobre as populações alvo. Dessa maneira, o objetivo do presente estudo é investigar os impactos de uma experiência de um Programa de Educação Musical sobre os aspectos psicológicos de seus estudantes, mais especificamente a autoestima, as habilidades sociais e o funcionamento executivo. Para isso, foram formados dois grupos experimentais com crianças e adolescentes de 10 a 17 anos matriculadas no PEM selecionado e um grupo controle com jovens da mesma faixa etária, sem prática musical e oriundos das mesmas escolas regulares. Com estes participantes foram utilizados testes psicológicos para mensurar os aspectos referidos no objetivo do estudo. Complementarmente aos testes foram realizadas entrevistas semi-estruturadas com estudantes 
do PEM, seus responsáveis legais e profissionais do PEM visando obter relatos de suas experiências e opiniões sobre os impactos do PEM em suas vidas. 



\section{Método}

\subsection{Aspectos Éticos}

O projeto de pesquisa foi apresentado ao Comitê de Ética em Pesquisa da Faculdade de Filosofia Ciências e Letras de Ribeirão Preto. Adotou-se os procedimentos básicos e éticos de respeito aos voluntários e à instituição, consoante com a resolução $n^{\circ}$ 466/12 sobre “pesquisa envolvendo seres humanos" (Ministério da Saúde, 2012). De acordo com o CAAE (Certificado de Apresentação para Apreciação Ética) n 31434914.6.0000.5407, o trabalho foi positivamente avaliado.

As instituições nas quais se pretendeu realizar a coleta dos dados foram contatadas visando averiguar o interesse em contribuir com o estudo Após o consentimento das direções, o projeto de pesquisa teve andamento com o convite aos participantes do estudo. As cartas de manifestação de concordância das instituições encontram-se em anexo (Anexos 1, 2 e 3).

Os participantes foram antecipadamente esclarecidos sobre os objetivos e procedimentos do referido trabalho, após o que, foram convidados a colaborar voluntariamente. Foi explicada a ausência de danos e riscos decorrentes de sua participação e a possibilidade de desistência a qualquer momento, sem que isto acarretasse qualquer ônus ao participante. Garantiu-se o sigilo quanto à identificação dos participantes. No caso dos estudantes, os que aceitaram participar voluntariamente levaram duas vias do Termo de Consentimento Livre e Esclarecido (TCLE) (Apêndice 1) para que um dos responsáveis assinasse, ficando com uma cópia do mesmo e devolvendo a outra para o pesquisador. $\mathrm{Na}$ ocasião do convite às crianças e adolescentes, o pesquisador indicava seu contato na segunda página do TCLE e se colocava a disposição para apresentação do trabalho e/ou possíveis esclarecimentos aos responsáveis legais. No caso dos adultos, aqueles que aceitaram participar voluntariamente assinaram duas vias do TCLE (Apêndice 2), ficando com uma cópia do mesmo e devolvendo a outra para o pesquisador. Os estudantes que possuíam mais do que 12 anos de idade e que aceitaram participar voluntariamente assinaram duas vias do Termo de Assentimento (TA) (Apêndice 3) ficando com uma via e devolvendo a outra para o pesquisador. Ressalta-se que o TA foi lido juntamente com cada estudante. 


\subsection{Participantes}

Participaram do estudo 69 estudantes com idades entre 10 a 17 anos, média de 12,4 anos (desvio padrão $=1,8$ ), sendo 31 do sexo masculino. Os participantes foram divididos em três grupos: a) Grupo Iniciante (GI): 23 alunos matriculados a menos de 12 meses no Projeto Guri com média de idade de 12 anos (desvio padrão = 1,9); b) Grupo Experiente (GE): 23 alunos matriculados a mais de 24 meses no Projeto Guri com média de idade de 12 anos (desvio padrão = 1,8); c) Grupo Controle (GC): 23 estudantes sem prática musical que frequentavam as mesmas escolas regulares dos participantes que compõem o GI e o GE com média de idade de 12,9 anos (desvio padrão = 1,2). Ressalta-se que além dos 69 participantes que integram os grupos experimentais referidos, foi realizada a coleta de dados com outros 10 participantes do Projeto Guri com tempo de matrícula entre 12 meses e 24 meses e que, portanto, não cumpriam os requisitos para a inclusão nos GI e GE. Dessa forma, os resultados obtidos por meio de testes psicológicos com estes participantes não foram considerados para fins de análise, todavia, as entrevistas foram incluídas.

Também foram participantes deste estudo:

- Seis responsáveis legais de estudantes matriculados no Polo do PEM;

- Um profissional administrativo do Polo do PEM;

- Quatro professores do Polo do PEM;

- Um Coordenador do Polo do PEM;

- Um Supervisor Operacional da Regional Administrativa do PEM;

- Dois Supervisores Educacionais da Regional Administrativa do PEM;

- Um Supervisor de Desenvolvimento Social da Regional Administrativa do PEM;

- Um Coordenador Regional da Regional Administrativa do PEM;

- Um Diretor de Desenvolvimento Social da Sede do PEM localizada na cidade de São Paulo. 


\subsection{Instrumentos}

Como instrumentos para a coleta de dados foram utilizados testes psicológicos com estudantes (GI, GE e GC) e entrevistas semi-estruturadas com profissionais do Projeto Guri, estudantes deste e seus responsáveis legais.

Os testes psicológicos utilizados para a coleta de dados com participantes estudantes foram:

- Escala de Autoestima de Rosenberg (EAR) (Anexo 4). A EAR é o instrumento mais utilizado para a avaliação da autoestima em virtude do reduzido número de itens, da linguagem simplificada, da fácil aplicação e da cotação breve e simples (Santos, 2008). Tratase de um instrumento unidimensional capaz de classificar o nível de autoestima em baixo, médio e alto. A baixa autoestima se expressa pelo sentimento de incompetência, inadequação e incapacidade de enfrentar os desafios; a média é caracterizada pela oscilação do indivíduo entre o sentimento de aprovação e rejeição de si; a alta consiste no autojulgamento de valor, confiança e competência (Rosenberg, 1965). O instrumento é constituído por 10 itens que devem ser assinalados através de uma escala Likert de quatro pontos com as seguintes opções de respostas: (1) Discordo totalmente, (2) Discordo, (3) Concordo e (4) Concordo totalmente. Dos dez itens que constituem a EAR, cinco são formulados de forma positiva e cinco são formulados de forma negativa. O respondente deverá escolher a resposta que melhor o define em cada um dos itens. Os itens 3, 5, 8, 9 e 10, formulados de forma negativa, devem ter sua pontuação invertida para a cotação dos resultados. Assim, de acordo com a EAR, quanto mais elevada a pontuação da pessoa, maior a sua autoestima. Para este trabalho foi utilizada a última atualização psicométrica da adaptação brasileira, realizada por Hutz e Zanon (2011), que incluiu a validação e normatização para diferentes idades e para crianças a partir de 10 anos.

- Matson Evaluation of Social Skills With Youngsters (MESSY) (Anexo 5). A MESSY é uma escala de autorrelato desenvolvida nos EUA por Matson, Esveldt-Dawson e Kazdin (1983) e está entre os instrumentos mais utilizados para mensurar habilidades sociais (Teodoro et al., 2005). O instrumento é formado por 62 itens que devem ser classificados pela criança ou adolescente em uma escala Likert de cinco pontos com as seguintes opções de respostas: (1) Não corresponde, (2) Corresponde um pouco, (3) Mais ou menos, (4) Corresponde um pouco e (5) Corresponde totalmente. A adaptação brasileira possui quatro fatores, a saber: Agressividade/Comportamento Antissocial (Fator 1), Habilidades 
Sociais/Assertividade (Fator 2), Vaidade/Arrogância (Fator 3) e Solidão/Ansiedade Social (Fator 4) (Teodoro et al., 2005).

-Teste de Stroop (Anexo 6). Este teste se baseia na evidência de é gasto mais tempo para nomear cores do que para ler os nomes das cores (Duncan, 2006). É uma das ferramentas mais utilizadas para avaliação de componentes do funcionamento executivo (Barros \& Hazin, 2013) e flexibilidade cognitiva (Klein et al., 2010). Trata-se de uma medida de controle executivo, autorregulação e de flexibilidade mental, mensurando a eficácia de concentração ao mesmo tempo em que desafia a capacidade de inibir uma resposta altamente condicionada em favor de uma outra não usual. É composto por duas tarefas, uma de leitura e outra de nomeação de cores e, para que os resultados sejam válidos, o pesquisador deve assegurar-se de que o participante reconheça e nomeie as cores sem hesitação (Castro, Cunha \& Martins, 2007).

Para a coleta de dados por meio dos testes psicológicos, o participante sentava-se em uma cadeira localizada em posição frontal à cadeira do pesquisador, havendo uma mesa entre os dois. Para responder à EAR e à MESSY, o estudante utilizava uma caneta esferográfica de cor azul e, antes do mesmo responder aos itens, os cabeçalhos de ambas as escalas eram lidos em conjunto com o pesquisador. O Teste de Stroop foi aplicado utilizando uma caneta esferográfica azul e um celular Nókia Lumia 635 com o aplicativo “Cronômetro" versão 3.2.0.0. As instruções eram passadas pelo pesquisador de acordo com a tarefa a ser realizada.

Foram realizadas entrevistas semi-estruturadas com estudantes do PEM, seus responsáveis legais e profissionais do PEM. Um roteiro de entrevista foi elaborado previamente pelo pesquisador para cada categoria de entrevistados, reunindo os grandes temas que se pretendia abordar (Apêndices 4, 5 e 6). Uma entrevista consiste numa conversa intencional (Bogdan \& Biklen, 1994) e, neste estudo, as informações obtidas por meio deste procedimento foram utilizadas como complementares aos dados coletados através da aplicação dos testes. Assim, objetivou-se dar oportunidade para que os participantes fornecessem relatos verbais utilizando a linguagem que lhe é própria sobre a sua experiência no PEM, incluindo aspectos relacionados à relação família-comunidade-PEM, a avaliação que fazem do Programa e os reflexos do mesmo em suas vidas.

As entrevistas foram realizadas individualmente, em diversos locais do PEM, tais como sala da coordenação, salas de aula e de estudo, a partir dos roteiros de entrevista e com o auxílio de um celular Nókia Lumia 635 com o aplicativo "Mini Recorder Free”, versão 2.4.2. 


\subsection{Procedimento}

No primeiro momento, a Diretoria Estadual do Projeto Guri foi contatada visando a apresentação do projeto de pesquisa e a solicitação de autorização para realização do mesmo com estudantes, responsáveis legais e profissionais da instituição.

Após a aprovação institucional (Anexo 1), foi iniciada a fase de coleta de dados com os GI e GE. Para essa etapa, o pesquisador verificou com a Coordenação local do Projeto Guri a possibilidade de dispor de uma sala, onde seriam realizados os testes e as entrevistas acima expostos. Ressalta-se que para escolha deste ambiente buscou-se assegurar que o mesmo seria silencioso e foi dada a orientação para que o processo de coleta de dados não fosse interrompido.

A partir da inserção no Projeto Guri, constatou-se que o mesmo não possuía o controle da data de matrícula de seus alunos e sendo esta uma informação importante para este trabalho, o pesquisador realizou um levantamento das fichas de matrícula de todos os estudantes visando obter as informações relativas ao tempo de inserção dos alunos no PEM. Em seguida, com a prévia autorização dos professores, o pesquisador se apresentou nas salas de aula dos estudantes, comunicando os objetivos da pesquisa e convidando os alunos a participar voluntariamente do estudo. Também foram realizados convites aos alunos durante os intervalos das aulas e em momentos de pausa das atividades. Foi feita a ressalva de que a recusa em participar da pesquisa não traria nenhuma consequência para o aluno. Estavam aptos a participar do estudo aqueles estudantes que trouxeram o TCLE assinado pelo responsável.

A coleta de dados no Projeto Guri foi realizada em duas etapas, a saber:

1) Aplicação dos testes psicológicos e realização da entrevista semi-estruturada com os estudantes do GI e do GE. A coleta de dados se deu de forma individual e a partir de um único encontro com cada participante, com duração aproximada de 40 minutos. Ressaltase que a entrevista foi realizada sempre ao final da sessão e os testes foram aplicados em ordem aleatória visando evitar viés nos dados.

2) Após a etapa de coleta de dados com os estudantes, foram realizadas entrevistas semi-estruturadas e individuais com os responsáveis legais e profissionais do Projeto Guri, que também assinaram duas vias do respectivo TCLE.

Destaca-se que todas as entrevistas autorizadas pelos participantes foram audiogravadas e a gravação posteriormente será destruída. 
A partir das entrevistas realizadas com os estudantes do Projeto Guri, foram identificadas as escolas regulares que estes alunos frequentavam e, assim, as escolas referidas com mais frequência foram convidadas a participar do estudo, com o objetivo de constituir o GC. As escolas contatadas foram divididas em três grupos: Escola Pública $(n=1)$, Escolas Particulares ( $\mathrm{n}=5)$ e Escola Particular da Indústria $(\mathrm{n}=1)$.

A participação da Escola Particular da Indústria não foi possível, pois os diretores referiram que, de acordo com regulamentos gerais, não era permitido que tal instituição integrasse estudos científicos. A Escola Pública referida com maior frequência pelos estudantes do PEM foi convidada a participar do estudo e respondeu positivamente. No total, foram convidadas cinco Escolas Particulares sendo que duas não aceitaram participar do estudo, uma não retornou os contatos do pesquisador e apenas duas consentiram em participar. A partir da aproximação do pesquisador destas últimas escolas, constatou-se que uma delas oferecia aulas sistemáticas de música na grade curricular, o que impossibilitava a inclusão dos alunos no GC. Assim, apenas a quinta Escola Particular convidada se enquadrou nos requisitos da pesquisa.

Os estudantes do GC foram convidados a participar do estudo seguindo o mesmo procedimento descrito para a formação do GI e do GE. A coleta de dados com o GC foi realizada de forma individual em um único encontro com cada participante no qual ocorreu a aplicação randômica da EAR, da MESSY e do Teste de Stroop.

\subsection{Local do estudo}

O presente estudo foi realizado no Polo do Projeto Guri sediado na cidade de Ribeirão Preto. No ano de 2015 este Polo contava com 345 vagas, que oscilaram entre 300 e 320 alunos divididos em 19 cursos e 51 turmas. O Polo funciona de segunda à sexta-feira das 8:00 às 18:00 e possui quatro turnos de aulas (Figura 3).

Vale ressaltar que neste Polo não são realizadas atividades pedagógicas às segundasfeiras, ficando este dia reservado a serviços administrativos e planejamento das atividades cotidianas da instituição, ou seja, atividades socioeducativas, apresentações artísticas e pedagógicas e avaliação dos trabalhos. O Polo possui um Coordenador, um Auxiliar de Polo, um Auxiliar de Coordenação, um Auxiliar de Serviços Gerais (terceirizada) e 19 professores. 


\begin{tabular}{|c|c|c|}
\hline Polo Ribeirão Preto & Turnos de aula & Instrumentos \\
\hline "Banda de Garagem" & $\begin{array}{l}\text { Terças e quintas-feiras pela } \\
\text { manhã }\end{array}$ & $\begin{array}{l}\text { - } \text { Bateria } \\
\text { - Guitarra } \\
\text { - Baixo elétrico } \\
\text { - Teclado/piano }\end{array}$ \\
\hline Cordas Friccionadas & Terças e quintas-feiras à tarde & $\begin{array}{ll}\text { - } & \text { Viola } \\
\text { - } & \text { Violino } \\
\text { - } & \text { Contrabaixo } \\
\text { - } & \text { Violoncelo } \\
\text { - } & \text { Percussão } \\
\text { - } & \text { Teclado/piano }\end{array}$ \\
\hline Violão, Percussão e Iniciação & $\begin{array}{l}\text { Quartas e sextas-feiras pela } \\
\text { manhã }\end{array}$ & $\begin{array}{ll}\text { - } & \text { Violão } \\
\text { - } & \text { Percussão } \\
\text { - } & \text { Iniciação musical }\end{array}$ \\
\hline $\begin{array}{l}\text { Coral, Madeiras, Metais e } \\
\text { Iniciação }\end{array}$ & Quartas e sextas-feiras à tarde & $\begin{array}{l}\text { - Iniciação musical } \\
\text { - Clarinete } \\
\text { - Saxofone } \\
\text { - Trompete } \\
\text { - Trombone } \\
\text { - Eufônio } \\
\text { - Tuba } \\
\text { - Flauta transversal } \\
\text { - Canto coral }\end{array}$ \\
\hline
\end{tabular}

Figura 3. Turnos de aulas do Polo do Projeto Guri de Ribeirão Preto

\subsection{Análise de Dados}

\subsubsection{Análise dos testes psicológicos}

Para comparar os escores finais dos testes psicológicos (EAR, MESSY e Teste de Stroop) entre os grupos de participantes (GI, GE e GC) foi utilizada a análise de variância ANOVA para os escores em que todos os grupos seguiam a normalidade averiguada pelo teste Kolmogorov-Smirnov. Para os dados em que ao menos um grupo não seguia a normalidade foi utilizado o teste não paramétrico de Kruskal Wallys.

Além da comparação inicialmente desenhada, uma segunda comparação foi realizada entre o GC e o Grupo Guri (GG), que englobava todos os estudantes do Projeto Guri em um único grupo, sem levar em consideração o tempo de permanência no Projeto. O GG incluía 
todos os integrantes do GI, GE e os 10 estudantes com tempo de matrícula entre 12 e 24 meses e que não haviam sido incluídos em nenhum grupo. Para as comparações entre o GC e o GG foi usado o teste t de Student quando os escores do GC seguiam a normalidade, caso contrário foi usado o teste não paramétrico de Mann-Whitney.

\subsubsection{Análise das entrevistas}

As entrevistas foram transcritas na íntegra e foram analisadas seguindo investigação qualitativa em educação de Bogdan e Bikken (1994). Para isso foram construídas "categorias de codificação".

“Categorias de codificação são construídas após leitura sistemática dos dados colhidos (diário de campo e entrevistas). A medida que os dados são lidos repetem-se ou destacam-se certas palavras, frases, padrões de comportamento, formas dos sujeitos pensarem e acontecimentos. $\mathrm{O}$ desenvolvimento de um sistema de codificação envolve vários passos: percorre os seus dados na procura de regularidades e padrões bem como de tópicos presentes nos dados e, em seguida, escreve palavras e frases que representam estes mesmos tópicos e padrões. Estas palavras ou frases são categorias de codificação."

(Bogdan \& Biklen, 1994, p. 221).

As categorias de codificação constituem um meio de classificar os dados descritivos que foram colhidos de forma que o material contido num determinado tópico possa ser fisicamente apartado dos outros dados.

A análise do material foi realizada através da interlocução com a produção acadêmica da área de PEMs, educação musical, neurociência e avaliação psicológica, além da experiência de José Abreu e produções não acadêmicas de músicos e acadêmicos que se envolveram com PEMs derivados do "El Sistema". Este recurso foi utilizado com o objetivo de construir um diálogo entre este modelo de intervenção social e as bases teóricas que o sustentam. 



\section{Resultados e Discussão}

Para a apresentação dos resultados, inicialmente será realizada uma análise institucional do Projeto Guri a partir das entrevistas realizadas com os profissionais e do diário de campo composto pelo pesquisador. O objetivo dessa análise é apresentar o PEM em que ocorreu o estudo visando a contextualização dos dados. Em seguida, serão demonstradas as análises estatísticas dos testes psicológicos aplicados aos GI, GE e GC. Por fim, serão apresentadas as categorias de codificação construídas a partir das entrevistas com profissionais do PEM, os estudantes deste e seus responsáveis legais.

No final de cada recorte de entrevista haverá a identificação do autor da fala. Um nome fictício foi criado para cada participante e será utilizado para sua identificação juntamente com a indicação da posição que ocupa em relação ao Projeto Guri (estudante, profissional ou responsável legal). No caso dos profissionais será indicado o cargo que ocupa no PEM e no caso dos responsáveis legais será indicado o grau de parentesco e o nome do estudante relacionado. Já no caso dos estudantes, será indicada a idade em anos, o tempo de envolvimento com o Projeto Guri em meses e o instrumento musical que estuda. Por exemplo, Luiz, 13 anos de idade, matriculado no Projeto Guri há 43 meses, estudante de violino, será identificado da seguinte forma: Luiz - 13 - 43, estudante de violino.

\subsection{Caracterização e análise institucional a partir da perspectiva dos profissionais}

Ao longo dos últimos anos, o Projeto Guri tem passado por diversas mudanças que acarretaram impactos em sua estrutura organizacional e no formato de suas intervenções. As vinhetas a seguir consistem em falas dos profissionais do Projeto Guri com relação a tais mudanças.

"Em 2006 houve uma grande expansão para o interior, aumentou de 100 Polos para 300. Passou a ser impossível manter a centralidade em São Paulo. Na época, supervisores estaduais indicavam supervisores regionais que iam duas vezes ao mês para a Sede em São Paulo para supervisão. E em 2008, houve a regionalização real, 
devido a necessidade de trabalho específico com os naipes (tipos de instrumentos). $\mathrm{Na}$ época, os instrutores (professores) eram cooperados e se tornaram contratados, a partir de um novo processo seletivo. Nesse período houve a abertura das regionais: São Carlos foi a primeira, Ribeirão Preto foi a última.

(Maura, Supervisora Educacional)

"A estrutura organizacional a gente chamava de triunvirato, que era o quê? Uma Regional (Administrativa) formada por uma área Administrativa, uma Educacional e uma de Desenvolvimento Social e que não existia uma hierarquia, não havia ninguém que supervisionava o trabalho e a Amanda não tinha nenhum tipo de gestão sobre a gente. Entre nós, era uma autogestão e, em relação ao campo, todos tinham que fazer seu trabalho, mas, porém havia uma disputa entre as áreas, isso se deu por conta do desenvolvimento institucional. A Diretoria de Desenvolvimento Social é a mais recente na formação. Ela possui cerca de sete anos. Então, quando ela (Coordenadora Regional) entrou no Guri ninguém entendia muito bem qual a função dela. E no triunvirato isso virava motivo de disputas ferrenhas. Até de como e qual a postura diante do educador, diante da Coordenação de Polo e tinha muito conflito por conta disso e como a Amanda não tinha gestão sobre nós, tudo tinha que ser recorrido pra Sede. Lembro das minhas colegas que trabalharam anterior a mim e elas falavam pra ligar pras Supervisoras em São Paulo sempre que havia uma discussão e de lá eles faziam algo de cima pra baixo (...). Como era peso igual para todos e ninguém para apontar o caminho... A Sede contratou uma assessoria externa que fez uma análise institucional e foi indicado que existisse em todas as Regionais a figura de um gestor de fato. Não no sentido técnico, mas no sentido de olhar o processo de trabalho, ver se ta acontecendo, cobrar... E a figura da Coordenadora Regional se tornou de gestão sobre a gente."

(Kátia F., Supervisora de Desenvolvimento Social)

"Mesmo pensando questões de vulnerabilidade, que é um indicador acompanhado, medido, supervisionado pelo Supervisor de Desenvolvimento Social. Só que nós, enquanto Coordenadores Regionais, a gente tem que organizar todo o trabalho do grupo para que a Kátia F., por exemplo, consiga fazer com que os Polos dela consigam atingir a meta de vulnerabilidade. Por que se não eu passo a não priorizar isso. É uma questão que se eu não acho relevante e acho que não diz respeito a mim e falo pra Kátia $F$. fazer outra coisa, outra coisa e não dou importância pra isso, então por mais que seja uma meta da Diretoria de Desenvolvimento Social eu também sou cobrada por esse resultado. Assim, tenho que organizar toda a equipe, até mesmo o Supervisores Educacionais pra cumprirem aquelas metas que é de uma Diretoria, mas que acaba sendo da organização como um todo. Antes, a Regional (Administrativa), não tínhamos visibilidade das metas da Diretoria de Desenvolvimento Social. Sabíamos por cima, mas não era minha responsabilidade isso. E nessa época cada um tinha suas metas. Cada um fazia seu trabalho. Você faz seu mestrado eu faço meu trabalho. A meta de vulnerabilidade social da Diretoria de Desenvolvimento Social é uma questão que é discutida com todos, então, no começo do ano, quando a gente vai fazer a divulgação dos Polos e organiza junto dos Coordenadores de Polo como vai ser feita a divulgação nas cidades... a gente envolve os Supervisores Educacionais na divulgação porque eles conhecem onde seria mais legal divulgar a música, que forma fazer isso, mas ao mesmo tempo esse planejamento está atrelado a Diretoria de Desenvolvimento Social porque a gente tem que chegar nos números de 
vulnerabilidade.(...) O Coordenador Regional faz essa gestão e cada um contribui com sua parte técnica e a gente teve mesmo um passo muito grande com essa mudança. Agora as metas são todas compartilhadas. São metas organizacionais, antes eram vistas como da Diretoria e se não eram da Diretoria não eram minha responsabilidade."

(Amanda, Coordenadora Regional)

"A área Educacional enfrentou um desafio. Aceitar que não haveria hierarquia das decisões. O olhar deveria ser múltiplo."

(Fernando, Diretor de Desenvolvimento Social - Sede)

Pesquisador: Como você avalia a proposta do Guri e operacionalização dela?

$V$ : Eu acho a proposta ótima... que admite muitos profissionais de qualidade, que ta trazendo educação musical de qualidade para o trabalho social. Desde que eu entrei aumentou em "Xtantada" vezes o número de educadores com compromisso maior. É aquela coisa, antes parecia um bico e hoje parece um emprego para se levar a sério e isso muda as pessoas que estão aqui dentro, você atrai pessoas sérias. E todo o apoio que é dado, uma área de educação musical, uma área administrativa e uma área de apoio social que você vai e busca e vai atrás, fazendo acontecer.

(Vitor, Professor)

Os relatos dos profissionais evidenciaram que as mudanças ocorridas nos últimos anos geraram desafios para todas as áreas, todavia, tais mudanças foram apontadas como importantes para um melhor funcionamento da Instituição e, também, para que fossem alcançados os objetivos derivados da missão essencial do Projeto Guri, ou seja, de desenvolvimento humano através do ensino coletivo da música. Apreende-se que as mudanças mais importantes apontadas pelos profissionais são: a criação da Diretoria de Desenvolvimento Social, a regionalização das decisões com consequente descentralização da gestão nas Regionais Administrativas, o compartilhamento de metas entre as Diretorias, a mudança do contrato de trabalho e a forma de seleção dos educadores.

A criação da Diretoria de Desenvolvimento Social inicialmente gerou conflitos na atuação entre as Diretorias, principalmente com a área Educacional, todavia, com o tempo, a necessidade de trabalho conjunto entre as Diretorias foi sendo melhor compreendida pelos profissionais que começaram a valorizar outras formas de agir frente às demandas sociais que perpassam o cotidiano do PEM. Esse processo fica evidente na fala de Roger, Supervisor Educacional. 
"Quando entrei achava que acontecia muito isso, eu acreditava que o Desenvolvimento Social seguia muito à risca o ECA (Estatuto da Criança e do Adolescente) e desautorizava o professor, mas fui descobrindo que o professor pode se impor sem violar direitos e a vertente social da Instituição não caminhava junto da vertente pedagógica musical. Uma coisa era isso, as duas Diretorias, a Social e a Educacional... eram diferentes as ideias, os pensamentos e a aplicabilidade do montante das atividades. Porque a gente usava a música como ferramenta para o desenvolvimento social, o humano. Mas a maioria dos funcionários não era conhecedora dos materiais, o que é o ECA, como ele funciona. A gente não tinha preparo, no meu caso, porque também não fui capacitado a isso. Eu fui aprendendo no campo com a equipe. Nossa equipe aqui é super sólida. Quando eu identifico algo, eu falo com a Coordenadora e já aciono a Kátia F. e a Fernanda (Supervisoras de Desenvolvimento Social). E a partir disso, a gente tem que multiplicar isso na nossa atuação. Hoje acho que nosso time está ganhando, não existe disparidade entre o social e a música, só existe desenvolvimento musical se existe o humano. Um puxa o outro e se eles continuarem caminhando assim vamos conseguir coisas muito boas, já tem coisas boas."

(Roger, Supervisor Educacional)

Conforme se nota no trecho, as mudanças organizacionais tiveram efeito transformador também em Roger. O desenvolvimento social é um dos objetivos do Projeto Guri, entretanto, não existiam ações focadas nesse campo até a criação da Diretoria de Desenvolvimento Social, pois se acreditava que ensinar música seria suficiente para obtenção do sucesso no desenvolvimento social. Com a criação desta Diretoria, a necessidade de garantir direitos para obter ganhos sociais se tornou foco das ações e os profissionais passaram a desenvolver os trabalhos conjuntamente. Conforme destaca Roger, "não existe disparidade entre o social e a música, só existe desenvolvimento musical se existe o humano" [sic] reforçando a compreensão de que o desenvolvimento musical está intimamente relacionado às iniciativas de garantia de direitos.

O foco das ações do Projeto Guri é a população infanto-juvenil, porém fica evidente que as transformações almejadas para esta população também atingem os profissionais na medida em que começam a mudar seu jeito de fazer e pensar o ensino musical. Roger entende a educação musical como meio de se obter o desenvolvimento humano. Para ele, a excelência de um é a do outro e vice-versa. Essa transformação pessoal se relaciona também ao que Shoemaker (2012) revela sobre o "El Sistema", ou seja, que o "El Sistema' parece agir simultaneamente (no desenvolvimento social e no processo de ensino musical) através de sua educação musical". No Projeto Guri, uma das mudanças organizacionais foi o compartilhamento de metas entre as Diretorias, de forma que não há meta de uma Diretoria 
que não seja da outra. Infere-se, a partir das falas dos profissionais, que as metas organizacionais tornaram o trabalho mais compartilhado, amplo e potente.

A forma de trabalhar em equipe proposta por meio das mudanças organizacionais, foi especialmente implementada na Regional do Polo estudado. Observou-se que o trabalho em equipe também é importante para os profissionais do Projeto Guri. Em diversos momentos, os profissionais revelaram a importância desse trabalho, como pode ser observado nos trechos abaixo:

"Eu percebi que melhorei como instrumentista quando eu parei para ouvir meus amigos tocando e a ouvir o professor. Eu percebi que se sou capaz de trabalhar com a Kátia F. (Supervisora de Desenvolvimento Social) eu sou capaz de trabalhar melhor do que sozinho."

(Roger, Supervisor Educacional)

"Eu gosto muito de trabalhar com as pessoas que eu trabalho. Nós temos discordâncias, mas ainda bem porque se não, não iríamos para lugar nenhum. Essa forma de resolver os problemas em grupo... Não resolve só o problema, também gera um desenvolvimento pessoal para cada um que está envolvido. Isso é uma coisa que o Guri... Eu não conseguiria em outra empresa fora do Guri nunca."

(Bernardo, Supervisor Operacional)

Após a criação da Diretoria de Desenvolvimento Social, para que a missão de desenvolvimento humano pudesse ocorrer, fez-se necessário que esta Diretoria e as outras trabalhassem em conjunto. $O$ desenvolvimento musical deve estar em relação com as realidades concretas vividas pelos estudantes e famílias. Por isso, a política de garantia de direitos da criança e do adolescente, trazida à tona pela Diretoria de Desenvolvimento Social, se relaciona diretamente ao ensino de música realizado pelos professores e Supervisores Educacionais. Assim, compreende-se que a criação da Diretoria de Desenvolvimento Social, dado seu caráter, conjuntamente ao pressuposto do trabalho em equipe, faz com que todos os profissionais, independentes de sua função, estejam implicados com as questões sociais. E é neste contexto que Roger compara a importância do contato com os colegas instrumentistas e o contato com Kátia F., indicando que o propósito do trabalho compartilhado provoca reflexos positivos em sua prática.

Bernardo também aponta para a importância do trabalho em equipe. Segundo ele, por meio do trabalho coletivo se alcança mais do que melhores resultados, se alcança 
"desenvolvimento pessoal” [sic]. Observa-se a partir das falas de Bernardo e Roger que o desenvolvimento pessoal, tão prezado quando se fala dos estudantes do PEM, também é percebido pelos profissionais com relação às suas próprias vidas. As falas de Roger e Bernardo evidenciam transformações relacionadas com a maneira como os espaços coletivos são percebidos e vivenciados por estes profissionais. Compreende-se que tais transformações ocorrem concomitantemente ao desenvolvimento de habilidades para a ocupação de espaços grupais, fomentando o sentimento de bem-estar psicossocial causado pela sensação de pertencimento a estes ambientes.

O trabalho em equipe associado a criação da figura do Coordenador Regional com responsabilidade de gestão sobre o trabalho dos Supervisores Regionais e dos Coordenadores de Polo fez com que as decisões passassem a ser tomadas no território, ou seja, onde acontecem os problemas e as dificuldades. Isso potencializou o processo de trabalho e tornou os trabalhadores mais autônomos em relação à Sede. A fala a seguir, da Coordenadora Regional, evidencia o processo de trabalho atual da Regional Administrativa:

"Ano passado os Supervisores Educacionais tiveram que fazer uma avaliação de todos os alunos dos Polos, então, foi uma super... A gente não tem avaliação de aluno, a gente não faz avaliação, mas a Diretoria Educacional queria saber mais ou menos o nível que estava e fizeram umas balizas para tenta mensura isso e os Supervisores Educacionais foram Polo a Polo para aplicar essa avaliação e ver como estava o nível dos alunos. Como foi uma ação muito grande. Porquê, para todos os Supervisores passarem em todos os Polos em um semestre, precisa mudar muita coisa da rotina. Então, todo mundo se organizou para contribuir para que eles conseguissem concluir e, anteriormente, a gente nem perguntava como está indo, perguntava por camaradagem, mas não se envolvia com a questão. Então, foi uma mudança de paradigma que com certeza favoreceu o trabalho de todo mundo e que com certeza favoreceu o trabalho dos Polos e que acaba chegando nos alunos, né, que é o objetivo final do nosso trabalho."

(Amanda, Coordenadora Regional)

A fala de Amanda traz o exemplo de uma ação proposta pela Sede, via Diretoria Educacional, que implicou na mobilização de todos os profissionais da Regional e dos Polos. Segundo a entrevistada, essa tarefa compartilhada ocasionou "uma mudança de paradigma" [sic] com relação à forma como a atuação do PEM era compreendida pelos profissionais. Para Amanda, esta nova compreensão dos processos de trabalho mais integrada e compartilhada teve impactos positivos inclusive para os alunos. Além disso, essas mudanças fizeram com 
que as Regionais Administrativas pudessem se organizar em função das necessidades que identificavam em seus Polos Referência e em seu processo de trabalho. Assim, infere-se por meio dos relatos que essa nova forma de trabalho ganha mais sentido na medida que é realizada de maneira multidisciplinar. Neste cenário, a Coordenação Regional e de Polo ganham papel importante no novo formato institucional, conforme salienta Amanda no seguinte trecho:

"Acho que primeiro é uma questão de trabalho em equipe. São vários fatores, porque eu acho que a nossa equipe tem muitos pontos positivos e isso favorece um monte de outras coisas, não só o andamento da reunião de equipe. Mas a nossa equipe funciona como uma equipe de verdade. Eu digo isso porque eu vejo outras Regionais, porque eu tenho colegas que são Coordenadores de outras Regionais e a gente troca nossas informações. A gente faz nossas reuniões de Coordenadores Regionais e quando a gente tem as capacitações na Sede a gente fica só no grupo de Coordenadores e conversamos sobre o funcionamento das Regionais. $E$ tem Regionais que o Coordenador Regional não conversa com o Supervisor Educacional, não conversa, assim, porque não te tolera, porque não consegue conviver com você. (...) Então assim, enquanto a gente tá na reunião todo mundo solta uma piada ou conversa paralelamente e não do assunto debatido, mas todo mundo respeita, todo mundo ouve o que tá sendo discutido, dá opinião quando acha que tem algo a colaborar em outras Regionais ... A nossa reunião dura quatro horas. A de amanhã marcamos para começar às nove horas e não vai ter hora para acabar. Assim, pode ultrapassar o teto que costuma ser meio dia, meio dia e pouco. Em outras Regionais, a reunião dura uma hora, quarenta minutos. Não são discutidos os assuntos, o Coordenador Regional chega para reunião e fala assim que queria compartilhar com vocês que 'aconteceu isso' essa semana, não se discute caso, fala da mudança orçamentária, da verba de viagens que subiu, caiu, fala do afastamento... Em uma hora acaba a reunião porque às vezes não tem uma ... o Coordenador Regional não faz a gestão adequada dos assuntos, não colabora. Pessoas que falam que o Coordenador Regional que não dá atenção paras outras áreas... então, ainda tem Coordenador Regional que ainda funciona nesse modelo (...)."”

(Amanda, Coordenadora Regional)

Infere-se a partir da fala de Amanda que ainda existem modelos conflitantes de gestão e atuação nas Regionais Administrativas e Polos do Projeto Guri. A noção de desenvolvimento integrado, social e musical, parece ainda não estar disseminada por todas as Regionais do Projeto Guri. A forma de seleção dos profissionais, a atualização dos contratos de trabalho e as capacitações podem constituir iniciativas de adequação da prática do profissional às novas maneiras de compreender sua atuação e os impactos desta para o PEM. 
Ao longo das entrevistas, conforme exemplificado nos trechos a seguir, estes fatores foram apontados como fundamentalmente importantes nos processos de mudança empreendidos.

Pesquisador: E o Guri, como se deu?

V: Quando entrei na faculdade, em 2007, o Guri era cooperativa e eu conhecia a professora de coral. Ela precisava de um tecladista acompanhante para o coral e ela me convidou. Eu aceitei, mas fiquei um mês só, acabei largando por conta da faculdade. (...) Em 2009, o Guri virou CLT (Consolidação das Leis do Trabalho) $e$ abriu processo seletivo, tinha Unimed, tinha várias formas de prestar e eu prestei como tudo e passei em tudo e desanimei porque acabei só pegando a iniciação musical com quatro horas de aula. No fim do ano, ofereceram o curso de teclado, com aulas só à tarde. Depois abriu de manhã e depois Barrinha e aí minhas horas passou de quatro para vinte e o Guri começou a ficar com capacitações, cursos e o trabalho com crianças que comecei a sentir assim... Começar a ver alguns meninos que evoluíram e você vê que o curso fez uma diferença na vida da pessoa, que a família às vezes não ganha nada. E eu tinha isso para mim, que eu vou trabalhar com não sei o que, mas sempre vou ter um vínculo com algum trabalho comunitário ou social. Isso vem desde a adolescência e aqui juntou as coisas, um emprego, um trabalho que propicia uma estrutura adequada para desenvolver um trabalho legal e ao mesmo tempo um contato com as crianças com esse tipo de coisa e o Guri virou uma prioridade.

(Vitor, Professor)

"O processo seletivo dos Supervisores Educacionais foi extremamente técnicomusical e aí a Instituição vem e pede que ele olhe diário de classe de educador, fazer papel de gestor, tem que cobrar e não somente a execução musical e 'eu não sou contratado para fazer trabalho administrativo'. Isso no triunvirato virava uma disputa. Quando a Amanda assumiu a figura de gestora ela fala 'eu olhei a atribuição de cargos e você tem que fazer' e isso foi muito importante."

(Kátia F., Supervisora de Desenvolvimento Social)

Conforme pôde ser observado nas entrevistas, alguns educadores já possuíam o desejo de desenvolverem alguma atividade comunitária ou social e isso se tornou possível devido às garantias trabalhistas conquistadas no Projeto Guri a partir do momento em que a seleção de professores passou a incluir os contratos de trabalho dentro da CLT. Assim, ao invés de continuarem como cooperados com contratos de trabalho mais frágeis, os educadores puderam atribuir ao Projeto Guri um lugar de "prioridade” [sic] em suas vidas.

Ainda assim, conforme destaca Kátia F., o processo seletivo dos educadores não os seleciona para a atividade múltipla que terão que desempenhar. Nesta perspectiva, o aprendizado advém do cotidiano de trabalho. Como consequência, algumas formas de atuação 
dentro do Projeto Guri permanecem arraigadas numa visão focada apenas na educação musical, desconsiderando as necessidades sociais concretas visando o desenvolvimento humano. E, dado este cenário, conforme já foi destacado, compreende-se que seja uma prerrogativa de qualquer ação de intervenção social que esta seja elaborada e desenvolvida com base no contexto para o qual está voltada. A fala a seguir ilustra como esse processo pode se dar no cotidiano de trabalho:

"Pesquisador: E as metas, vêm todas via Sede? Por exemplo, sua ação aqui e em Barrinha é a mesma?

$V$ : Não. Eu não lido com a grande circulação de alunos. Mas Barrinha e aqui é diferente, aqui, por atender um público talvez mais escolarizado eu tenho condições de ofertar, trabalhar um processo metodológico mais puxado, preocupado mesmo com a música. Aqui Guri não chega com fome, não tem essa preocupação. (...) Lá tem que partir de uma premissa social para atingir o musical; aqui a coisa é mais direta. $O$ que vem da Sede são os objetivos. Eu conheço minha turma no começo do semestre e em um mês eu tenho que entregar meu planejamento. Eu tenho um aluno de 18 anos e um de oito e isso tem que fazer sentido. Se um Polo tem problema de racismo, vamos fazer um trabalho com essas crianças sobre isso. Se dá para levar pra música, vamos levar pra música".

(Vitor, professor)

Vitor organiza suas aulas de acordo com as realidades dos Polos que leciona, ou seja, centra o foco de sua aula de música nas necessidades dos estudantes. Para este educador, integrar as ações musicais às sociais parece ser uma de suas metas em sala de aula.

Outro fator apontado como importante para o sucesso das ações desenvolvidas pelo Projeto Guri é a continuidade da ação. As falas abaixo retratam alguns pontos de vista a respeito dessa temática:

"Até porque é 100\% gratuito, as pessoas têm muito interesse, é uma coisa legal, a gente vê que funciona, não é uma coisa assim, uma semana tem aula e na outra não sabe se vai ter".

(Amanda, Coordenadora Regional).

"Eu vejo muito projeto social com começo, meio e fim. Eu acho que por ser uma política pública é uma grande vantagem e não ser uma organização da sociedade civil que se organizou como ONG e conseguiu financiamento no CMDCA (Conselho Municipal dos Direitos da Criança e do Adolescente) que tem início meio e fim. $O$ Guri existe há 21 anos e esse é o grande diferencial do Guri, algo que me faz admirar 
o trabalho. Porque às vezes você pega uma semente, faz virar um brotinho e você vira e abandona, acho isso muito cruel."

(Kátia F., Supervisora de Desenvolvimento Social)

"Guri veio lavar a alma. Projetos normalmente trabalham nas atividades sócio educativas, esporte, cultura. Quando o trabalho é com música é sempre de uma forma primária, sem objetivo e foco. Falta equipamento, um violão por sala, e de estrutura, falta conteúdo. Atividades para preencher o tempo. Guri oferece atividade musical, mas ensina de verdade, tem o instrumento e o profissional qualificado para ensinar. Guri cumpre as exigências. Tem que ser mais do que "matar o tempo", "para o pobre qualquer coisa serve"”.

(Fernando, Diretor de Desenvolvimento Social - Sede)

A partir das falas, é possível identificar determinadas características valorizadas em PEMs em geral, que são: continuidade da ação, acesso universal, garantia de financiamento, organização e valorização da população atendida. Segundo Booth (2013), essas são algumas das características que fazem do "El Sistema" o PEM de maior sucesso no mundo. E, conforme se observou nas entrevistas, essas características também estão presentes no Projeto Guri.

Apreende-se, através das entrevistas, que existem pelo menos dois tipos de projetos sociais, aqueles que têm tempo delimitado de existência e aqueles que são permanentes, ou seja, que não possuem um prazo para o encerramento de suas atividades, conseguindo ofertar uma ação contínua frente a uma demanda social. Os projetos sociais que acontecem por meio de editais ou que permanecem por um período mais curto têm um alcance menor em relação aos projetos permanentes, podendo culminar na situação descrita por Kátia F. através da metáfora da semente, que chega a virar broto, mas é abandonada antes de dar frutos. Além disso, muitos destes projetos proporcionam ocupação temporal, mas não fornecem atividades de qualidade e tampouco se preocupam com os impactos de suas ações nos sujeitos afetados por elas.

O Projeto Guri recebe financiamento público e, dessa maneira, se configura como uma política pública, tendo caráter permanente. Devido a esta característica, recebe verbas públicas anuais e, assim, consegue realizar programações de longo prazo, como os estudos internos e as mudanças organizacionais citados anteriormente. Por ser uma política pública, o PEM deve seguir a meta colocada à AAPG pela Secretaria de Cultura do Estado de São Paulo de pelo menos $70 \%$ de estudantes classificados como estando em situação de vulnerabilidade social. O Projeto Guri possui um indicador próprio de vulnerabilidade social, sendo a renda 
per capita a principal variável. Este valor é de 3/4 do salário mínimo federal. De acordo com o Relatório Anual de acompanhamento realizado pela AAPG, "são considerados vulneráveis socioeconomicamente os alunos/famílias que, para ter acesso a bens culturais de prestígio social ou ampliação do repertório sociocultural, deveriam destinar recursos em detrimento de seu sustento próprio (moradia, saúde, escolaridade, entre outros).” (AAPG, 2015, p. 31). Ressalta-se que fatores como portar alguma deficiência ou síndrome genética ou adquirida também são considerados para classificar um estudante como estando em situação de vulnerabilidade social.

Historicamente, o Polo estudado apresenta números inferiores à meta de vulnerabilidade social, como indicado pelos seguintes trechos.

"A gente tem uma meta de vulnerabilidade sim, 70\%. A gente está buscando é esses alunos. Então por não estar numa região que vai de encontro com esses alunos, talvez por isso a gente não consiga atingir. Hoje eu já não sei te fala se agente atingiu. Mas provavelmente a gente deve ter aumentado um pouquinho de $50 \%$ para $60 \%$, algo assim."

(Priscila, Coordenadora de Polo)

"A Priscila estava muito próxima (meta de 70\%) e isso foi inédito na história do Polo e sempre se justificava assim, o Polo regional não consegue atingir a meta de vulnerabilidade porque está numa região nobre e isso até as Diretorias justificavam e eu era a única que falava que na minha visão não é essa a justificativa, está numa área nobre, mas se for pensar não está tão distante do centro, vários ônibus passam próximos e eu achava que era um problema de atuação de Coordenação de Polo, porque o Polo teve muitas entradas e saídas de Coordenadores até chegar a Priscila"

(Amanda, Coordenadora Regional)

Infere-se das falas que o papel do Coordenador de Polo é imprescindível para que o PEM alcance suas metas. Diversos Coordenadores estiveram à frente do Polo de Ribeirão Preto, mas o índice de estudantes em vulnerabilidade social só aumentou após a chegada de um Coordenador que entende o desenvolvimento musical atrelado ao social como evidenciado no seguinte trecho:

"Eu acho que aqui a gente trabalha com tudo isso. A gente lida com pessoas. Não deixa de ser uma liderança, a gente busca parcerias, tanto no sentido de redes, em 
várias áreas, educacional, artística, saúde para essas crianças. E trabalha com agendas, né, porque precisa disso. Ainda mais o Polo de Ribeirão Preto que não tem uma parceria, a gente precisa sempre buscar um espaço extra porque aqui não comporta os pais mais os alunos. Então, é trabalhar essa agenda do Guri todo semestre. Não só em função dos alunos, mas em relação a equipe, né? Planejar trabalhos socioculturais com as crianças e os adolescentes em vários temas. Dialogando com o trabalho de planejamento semestral deles, ou não, num trabalho que vai atender a necessidade de algum educador, de algum curso específico ou vinda do aluno, por exemplo, em relação a disciplina, educação, da saúde, em algum aspecto em relação a isso. (...)Buscar parcerias ou estreitar para poder entender, porque, tudo isso impacta no Guri. A mãe quer sair, ou não quer ou por quê que quer sair? De repente, a gente, entendendo a história de perto, a gente consegue ajudá-la e resolver de uma forma muito simples, porque às vezes a família não tem perna para isso. Ou não tá conseguindo enxergar ou encontrar um caminho e não encontra possibilidades e, como nós temos vários contatos, a gente já consegue resolver"

(Priscila, Coordenadora de Polo)

Priscila trabalha em rede, buscando acionar os diversos equipamentos sociais que pertencem à comunidade que o Polo integra. Segundo ela, esta rede de contatos é usada para resolver dificuldades das famílias que, inclusive, podem extrapolar a atividade musical, mas dada a vertente social deste PEM, são olhadas de forma especial sob a compreensão de que "tudo isso impacta no Guri" [sic].

Hoje, devido à política de incentivo a realização de ações mais amplas e integradas, é grande a demanda por atividades socioeducativas nos Polos e durante o período da coleta de dados o pesquisador pôde participar da organização e desenvolvimento de uma delas. O Polo vinha enfrentando dificuldades com alguns alunos relacionadas à sexualidade e este fato gerou a necessidade de se pensar uma ação educativa para problematizar a temática da diversidade sexual com os estudantes e os profissionais. A ação foi pensada conjuntamente com a Coordenadora de Polo, a Supervisora de Desenvolvimento Social, o Assistente de Polo e o pesquisador, além de conversas entre a Coordenadora e os professores.

Para a ação, foi convidado um membro da Comunidade LGBT (Lésbicas, Gays, Bissexuais, Travestis, Transsexuais e Transgêneros). A ação teve como foco o debate com os estudantes sobre o tema e, posteriormente, foi realizada uma reunião entre os professores e a Coordenação visando avaliar a atividade. Nesta ocasião, avaliou-se que esta atividade proporcionou o contato dos alunos com a temática, indicando a importância da construção de espaços cujo propósito seja a reflexão e o debate de ideias. Neste momento, também foram discutidas estratégias para adequação do formato das atividades desta natureza, visando favorecer que os adolescentes participem mais ativamente, contribuindo com suas próprias 
opiniões e experiências. Assim, o pesquisador teve a oportunidade de participar da implementação de uma ação específica do Polo do Projeto Guri de Ribeirão Preto, elaborada a partir de demandas deste Polo, o que evidencia a autonomia dos Polos para pensar ações que correspondam ao cotidiano de cada PEM e a preocupação com o desenvolvimento de ações que, na mesma medida, extrapolem e perpassem o ensino da música. Esta ação evidenciou, ainda, a importância da Coordenação de Polo estar em sintonia com os princípios norteadores de PEMs, ou seja, de integração da educação musical às realidades concretas vividas nos Polos.

Ainda sobre a valorização de iniciativas de inclusão social, nota-se que a missão do Projeto Guri é semelhante à do "El Sistema" e dos PEMs derivados deste. Isso permitiu a aproximação dos dois Programas, com a participação do "El Sistema" no encontro de formação dos profissionais do Projeto Guri, realizado no final de 2013. Nesta ocasião, um educador do "El Sistema" foi convidado a falar sobre o trabalho de inclusão de crianças e adolescentes deficientes realizado na Venezuela e, a partir desta parceria, o Projeto Guri começou a implementar as ações semelhantes, derivadas da cooperação entre os dois PEMs. Tais ações, atualmente, são principalmente focadas no público deficiente visual. Hoje, o Projeto Guri conta com software e impressora específicos para impressão de partituras em braile e isto foi possível devido à parceria com o "El Sistema".

Alguns desdobramentos dessa cooperação ainda não estão definidos institucionalmente, porém, em outubro de 2015, um grupo referência de estudantes escolhidos do Projeto Guri foi para a Venezuela participar do Festival Villa Lobos (AAPG, 2014). Outro exemplo de intercâmbios entre PEMs internacionais é o Programa de Intercâmbio Musicians and Organizers Volunteer Exchenge (MOVE), criado pela Jeunesses Musicales International, associação sediada na Bélgica que reúne diversas organizações musicais em cerca de 70 países. Em 2016 esta organização levará dois alunos do Projeto Guri para Malawi e outros dois para Noruega, além de trazer dois estudantes da Noruega e Moçambique para o Polo do Projeto Guri da cidade de São Carlos. 


\subsection{Análise dos testes psicológicos}

A partir dos resultados estatísticos apresentados (tabela 1), nota-se que as médias dos escores da EAR e do fator 4 (Solidão/Ansiedade Social) da MESSY apresentaram diferenças entre os grupos de participantes. Os dados estatísticos também mostram que os escores de ambas as escalas são iguais para os GI e GE e diferentes para o GC. 
Tabela 1 - Comparação das médias dos Grupo Controle $(n=23)$, Grupo Iniciante $(n=23)$ e Grupo Experiente $(n=23)$ em relação ao escore de cada teste psicológico.

\begin{tabular}{|c|c|c|c|c|c|c|}
\hline \multirow{2}{*}{ Instrumento } & \multicolumn{3}{|c|}{ Grupos (Médias) } & \multirow[b]{2}{*}{ F ou $X^{2}$} & \multirow[b]{2}{*}{ g.l. } & \multirow[b]{2}{*}{$\mathbf{p}$} \\
\hline & Controle & Iniciante & Experiente & & & \\
\hline $\begin{array}{l}\text { Escala de Autoestima de } \\
\text { Rosenberg }\end{array}$ & $39,13 *$ & 58,70 & 57,39 & 3,97 & 2,66 & 0,02 \\
\hline $\begin{array}{c}\text { MESSY - Fator 1: } \\
\text { Agressividade/ } \\
\text { Comportamento } \\
\text { Antissocial }\end{array}$ & 37,70 & 32,39 & 35,17 & 1,59 & 2,66 & 0,21 \\
\hline $\begin{array}{c}\text { MESSY - Fator 2: } \\
\text { Habilidades Sociais/ } \\
\text { Assertividade }\end{array}$ & 108,43 & 100,39 & 100,96 & 2,67 & 2,66 & 0,07 \\
\hline $\begin{array}{l}\text { MESSY - Fator 3: } \\
\text { Vaidade/Arrogância }\end{array}$ & 14,00 & 12,52 & 12,61 & 0,57 & 2,66 & 0,56 \\
\hline $\begin{array}{c}\text { MESSY - Fator 4: } \\
\text { Solidão/Ansiedade Social }\end{array}$ & $15,87 *$ & 13,74 & 13,70 & 3,32 & 2,66 & 0,04 \\
\hline $\begin{array}{c}\text { Teste de Stroop - Tempo } \\
\text { de Leitura** }\end{array}$ & 65,09 & 74,78 & 71,09 & 2,88 & 2,66 & 0,17 \\
\hline $\begin{array}{c}\text { Teste de Stroop - Número } \\
\text { de Resposta** }\end{array}$ & 112 & 111,48 & 112 & 2,23 & 2,66 & 0,36 \\
\hline $\begin{array}{c}\text { Teste de Stroop - Tempo } \\
\text { de Nomeação }\end{array}$ & 118,35 & 117,26 & 117,65 & 0,13 & 2,66 & 0,87 \\
\hline $\begin{array}{l}\text { Teste de Stroop - Número } \\
\text { de Respostas de Nomeação }\end{array}$ & 88,22 & 85,13 & 88,17 & 0,23 & 2,66 & 0,79 \\
\hline
\end{tabular}

A partir das análises estatísticas, observa-se que os níveis de autoestima dos estudantes do Projeto Guri são maiores do que de crianças e adolescentes que não fazem parte deste PEM. Segundo Freire e Tavares (2011), níveis mais elevados de autoestima sugerem maior satisfação com a vida, além da possibilidade destes jovens atribuírem maior significado a diversos domínios da vida. Além disso, de acordo com Baumeister et al. (2003), o nível 
elevado de autoestima é preditor de saúde mental e está correlacionado ao desempenho acadêmico.

Da mesma forma, a partir dos resultados mensurados pelo fator 4 (Solidão/Ansiedade Social) da escala MESSY, infere-se que os estudantes do Projeto Guri quando comparados aos participantes que não fazem parte deste PEM são acometidos em menor intensidade por sentimentos de solidão e ansiedade social. O suporte social parece estar associado à resiliência e, segundo Turner et al. (2015), o baixo nível de suporte familiar e dos pares é correlato ao aumento das vitimizações sofridas. Dessa maneira, a capacidade dos PEMs de prover ambientes socialmente enriquecidos pode dar a sensação de pertencimento, reduzindo o sentimento de solidão e ansiedade social. Durante sua estadia no Projeto Guri, o pesquisador pôde notar que os estudantes estão em contato social durante todo o período de sua permanência no Polo, ou seja, desde sua chegada, até durante as aulas e na saída. Foi possível observar, ainda, que todos esses momentos são repletos de conversas, brincadeiras, lanches, música e encontros.

Vale destacar que nenhuma das comparações realizadas apresentou diferenças entre GI e GE. Caso tivessem sido encontradas, essas diferenças indicariam efeitos do tempo de permanência dos alunos no PEM com relação aos fatores testados. Assim, concluiu-se que o tempo de permanência no Projeto Guri, ao menos de acordo com o desenho metodológico desta pesquisa, não apresentou impactos nos fatores mensurados.

A respeito deste achado, conjeturou-se que estar envolvido com o Projeto Guri há até 12 meses pode significar uma vivência muito extensa no cotidiano deste PEM para que estes alunos fossem considerados como "iniciantes". Assim, hipotetizou-se que estudantes matriculados há mais de três meses já apresentariam um envolvimento significativo com a metodologia e o ambiente do PEM. A partir desta hipótese, foram realizadas novas comparações entre iniciantes e experientes, porém reduzindo o tempo de atividade do aluno considerado "iniciante”. Para isto, foram selecionados os quatro participantes matriculados no PEM há no máximo três meses constituindo, assim, um "Grupo Iniciante” mais restrito. Utilizando o teste não paramétrico Mann-Whitney, os escores dos testes psicológicos deste grupo foram comparados com os escores de um grupo formado pelos seis alunos matriculados há mais de 38 meses no PEM. Porém, nenhuma diferença foi encontrada entre tais grupos. Faz-se necessário aumentar o controle da variável tempo de envolvimento, garantindo que o GI seja formado por estudantes que ainda não tenham tanto envolvimento com PEMs.

Infere-se que as diferenças encontradas através da análise estatística entre o GC e o Grupo Guri (GI e GE) mostram que é possível que a entrada no PEM esteja associada a 
fatores motivacionais de incentivo e escolha que podem ser determinados não só por fatores individuais, mas também por relações familiares. Assim, hipotetiza-se que as diferenças entre GC e Grupo Guri podem ter surgido antes dos participantes se envolverem com o PEM. Essa possibilidade é interessante de ser examinada, pois traz à cena o papel família para o desenvolvimento do aluno. Esta compreensão resgata a ênfase no papel da família tão valorizada pelo modelo do "El Sistema" (Abreu, 2009; Booth, 2013, Creech et al., 2013; Majno, 2012; Uy, 2012). As interações entre os elementos do tripé do processo educativo do "El Sistema", ou seja, indivíduo-família-comunidade, e o desenvolvimento da criança são dinâmicos no decurso temporal (antes e depois da matrícula).

Destaca-se que o Teste de Stroop e os fatores 1 (Agressividade/Comportamento Antissocial), 2 (Habilidades Sociais/Assertividade) e 3 (Vaidade/Arrogância) da MESSY não apresentaram diferenças significativas para nenhum dos grupos testados. Ávila et al. (2009) utilizaram testes psicológicos, dentre eles o Teste de Stroop, para avaliar o efeito do nível educacional no funcionamento cognitivo de idosos. Os autores verificaram que há influência do nível educacional no desempenho em medidas cognitivas, dentre elas o funcionamento executivo. Da mesma maneira, o resultado do presente estudo para o Teste de Stroop mostra homogeneidade entre os escores dos GC, GI e GE o que pode indicar que as semelhanças encontradas advêm da mesma origem dos participantes, especialmente por frequentarem as mesmas escolas regulares. Isso aponta para a necessidade de implementar avaliações que utilizem testes psicológicos que mensurem os fatores já testados utilizando a metodologia grupo controle.

\subsection{Análise das entrevistas: Indicadores de estados psicológicos e fatores de contexto}

A partir da análise das entrevistas, foram construídas três categorias de codificação que se referem às mudanças comportamentais percebidas nos estudantes relacionadas ao envolvimento com o Projeto Guri, a saber: "Relacionamento interpessoal”, "Desenvolvimento de habilidades intrapessoais" e "Envolvimento com música e desenvolvimento humano na perspectiva de profissionais e responsáveis legais". As duas primeiras categorias de codificação representam as opiniões e reflexões dos estudantes acerca das mudanças percebidas em seus comportamentos relacionados ao envolvimento com o Projeto Guri. Já a 
terceira categoria de codificação é constituída apenas por falas de profissionais e responsáveis legais dos estudantes sobre a mesma temática.

\subsubsection{Relacionamento interpessoal}

O relacionamento interpessoal representa uma ampla gama de habilidades relacionais complexas. Ganhos nessa direção sugerem o desenvolvimento de habilidades sociais necessárias para formação de relacionamentos de qualidade (Teodoro et al., 2005). Ao longo das entrevistas, os estudantes relataram impactos no âmbito dos relacionamentos interpessoais decorrentes da participação no Projeto Guri. Os trechos selecionados para ilustrar este tópico abordam questões relativas à sociabilidade, às trocas interpessoais e ao exercício do convívio com outras pessoas.

"Aprendi a conviver em grupo. Como é coral, a gente se reúne bastante. E isso me mudou muito, eu tinha certa dificuldade de interagir em grupo e isso me ajudou bastante. E, às vezes, ela (professora) pede para gente fazer algum teatro ou cantar lá na frente e isso foi muito difícil, mas hoje é fácil."

(Maria - 17 - 15, estudante de canto coral)

"(Aprendi no PEM) o respeito pelas outras pessoas. Porque aqui tem muita criança e daí antes eu falava de tudo, qualquer barulho que a pessoa fazia eu falava "para", não tinha paciência."

(Bruna - 12 - 24, estudante de violoncelo)

"Antes eu era muito tímida, muito introvertida e agora eu sou mais animada. Eu não tenho outros amigos em outros lugares. Só aqui. Aqui é onde eu sou eu. Sei lá, acho que eu gosto daqui. (Nos outros lugares) eu fico quietinha, no meu canto. Já aqui já deu para perceber que eu sou bem animada. (Aqui) aprendi a ser eu. Porque sempre tem alguém que vem falar com você. Não importa o jeito como você seja, sendo você. Você não precisa mudar o seu jeito para uma pessoa gostar de você. Porque eu não sabia como conversar com as pessoas e agora eu sou mais calma, consigo fazer essas coisas."

(Tatiana - 17 - 46, estudante de viola)

"Na escola eu não tinha muito amigo e aqui eu desenvolvi, perdi a vergonha."

(Luiz - 13 - 43, estudante de violino) 
"Às vezes alguém quer pôr o som mais alto do que o do outro, mas não pode. Que tem que cada um vai ter seu momento e que eu acho que passando isso para vida real seria que se você hoje tá perdendo um dia você ganha."

(Douglas - 11 - 43, estudante de guitarra elétrica)

“(no PEM) Aprendi a ter um pouco de educação, a pedir ajuda.”

(Gustavo - 14 - 10, estudante de contra baixo)

"(no PEM) eu conversei mais com as crianças.”

(Salma - 13 - 10, estudante de viola)

As falas dos entrevistados revelam que, para os estudantes, o envolvimento nas aulas e nas atividades cotidianas do PEM contribuiu para que aprendessem a conviver em grupo, exercitando a tolerância e a negociação. Estar em grupo propiciou ganhos relacionais de diversas ordens, como mais educação, aumento do número de amigos e o consequente desenvolvimento de uma rede de suporte social. A partir dos trechos das entrevistas apresentados, percebe-se que o relacionamento interpessoal desencadeou o desenvolvimento de habilidades sociais complexas que, de acordo com os entrevistados, contribuíram para que passassem a se relacionar em grupo, o que sugere uma postura de abertura e disponibilidade para o contato com o outro. Os estudantes parecem ter desenvolvido a capacidade de melhor percepção do entorno e das pessoas que os cercam, podendo responder de maneiras mais adaptadas a eles. Em conformidade com este achado, Schellenberg, Corrigall, Dys e Malti (2015) sugerem que o treino musical em grupo é um facilitador do desenvolvimento de habilidades pró-sociais.

Infere-se que os relatos dos estudantes obtidos através das entrevistas a respeito das mudanças percebidas em seus relacionamentos interpessoais se relacionam com as diferenças entre os grupos de participantes observadas nos escores do fator 4 (Solidão/ Ansiedade Social) da escala MESSY. De acordo com Turner et al. (2015), para os adolescentes o relacionamento com pares está correlacionado ao sentimento de bem-estar psicossocial, enquanto a rejeição ou baixo suporte pelos pares está associado ao adoecimento. Assim, o ensino coletivo dos PEMs pode estar relacionado ao desenvolvimento de habilidades sociais que permitem aos estudantes envolvidos sentirem-se menos sós ou menos ansiosos diante de situações em grupo. Nesta direção, Creech et al. (2013) aponta que o trabalho em equipe é o principal impacto que pais e professores de PEMs baseados no "El Sistema" identificam nos estudantes. Dessa maneira, fica mais clara a diferença encontrada entre os estudantes do 
Projeto Guri e as crianças e adolescentes que não frequentam o PEM. Os dados obtidos por meio do uso da MESSY e da realização das entrevistas são corroborados pela literatura científica uma vez que outros estudos já apontavam resultados semelhantes, todavia sem que fossem utilizados testes psicológicos para a mensuração desses fatores psicológicos.

Ainda a este respeito, é interessante ressaltar que afora a evidente valorização dos espaços grupais, o fato de estar em grupo não significa a redução da individualidade dos estudantes. Para Marcela, tocar em grupo faz com que se sinta mais em evidência do que quando toca sozinha.

Pesquisador: E você, prefere quando está todo mundo junto ou separado?

M: Todo mundo junto. Por que sozinha o som do violino não aparece tanto, mas junto o som do violino parece que aparece mais, ele se destaca em conjunto.

(Marcela - 12-26, estudante de violino)

As apresentações pedagógicas e artísticas representam o fim do processo educacional semestral do Projeto Guri e são constituídas por performances de equipes que foram formadas no decorrer do semestre ou mesmo que já eram formadas há mais tempo. É interessante destacar que no cotidiano do PEM as aulas são realizadas em turmas de alunos de um mesmo instrumento. Assim, o encontro entre os variados instrumentos acontece apenas durante os ensaios e apresentações. Dado isto, a fala de Marcela desvela sua vivência de estar em grupo, sendo este o momento em que, apesar e por causa do fazer coletivo, ela consegue expor o seu fazer individual. Esta perspectiva enunciada pela aluna traz à cena aspectos importantes que remetem a princípios basais de PEMs, ou seja, a valorização do trabalho em equipe, a capacidade de avaliação do próprio desempenho e o sentimento de confiança diante de uma tarefa que domina (Creech et al., 2013).

Outro fator a ser destacado nesta categoria de codificação é o tempo de envolvimento dos estudantes com o PEM. Observou-se que muitas das falas selecionadas para ilustrar esta categoria foram proferidas por estudantes com menos de 12 meses de matrícula no PEM, o que os caracteriza, segundo os critérios utilizados nesta pesquisa, como Grupo Iniciante. Isto parece corroborar a hipótese apontada no item Análises dos testes psicológicos de que o envolvimento no PEM há mais de três meses já seria suficiente para que a participação deste ambiente influenciasse o comportamento dos estudantes. Dessa maneira, a divisão dos grupos experimentais inicialmente proposta para este estudo pode ter acarretado a inserção no GI de 
estudantes que já apresentavam um envolvimento considerável com o PEM, deixando a formação dos Grupos Iniciante e Experiente com composições semelhantes.

\subsubsection{Desenvolvimento de habilidades intrapessoais}

Nesta segunda categoria foram reunidas vinhetas em que os estudantes relataram os impactos gerados pelo envolvimento com o Projeto Guri na forma como percebem o próprio corpo, a capacidade de concentrar-se, a disciplina de estudos e seus planos para o futuro. Segundo Chanda e Levitin (2013) e Schellenberg (2005), o aprendizado musical está relacionado ao desenvolvimento de habilidades extras musicais.

"S: A minha postura melhorou

Pesquisador: Postura?

S: É. Minha coluna."

(Salma - 11 - 10, estudante de viola)

“(...) minha boca. Eu percebo que para tocar o eufônio e a flauta, a boca muda e minha boca estava acostumada com o eufônio e agora eu estou tendo que acostumar com a flauta."

(Carolina - 11 - 36, estudante de eufônio)

Salma e Carolina apontam mudanças físicas geradas pelo fazer musical. Para Bueno (2012), a música também está no corpo e, assim, para compreender o fenômeno musical não é possível desconsiderar seus impactos físicos. Este entendimento traz consigo a noção de desenvolvimento integrado biológico, psicológico e social, enunciada por Bueno (2012) e compartilhada pelo Projeto Guri.

A multiplicidade de transformações apontadas como resultantes das ações do PEM também podem ser notadas nas falas a seguir:

"Eu aprendi a ficar mais concentrado, ter mais paciência. É... Eu fiquei mais paciente..."

(Renan - 11 - 16, estudante de violoncelo) 
"Eu chego em casa estressado e venho para o Guri e, aí, me acalma."

(Luiz - 13 - 43, estudante de violino)

“(música representa) lazer, é algo que vou usar no futuro, ajuda a acalmar. (...) Acalmei um pouco, como disse antes. Melhorei a nota de matemática também. Falei para os professores que estava tentando melhorar."

(Gustavo - 14 - 10, estudante de contra baixo)

A melhora da disciplina e da concentração são aspectos apontados por Abreu (2009) como efeitos do envolvimento com o "El Sistema" e, como pôde ser observado nas vinhetas acima, Renan, Luiz e Gustavo revelaram que o envolvimento com o PEM e a prática musical contribuíram para que se percebessem menos estressados, mais calmos e mais capazes de se concentrarem A prática musical é uma atividade que demanda uma rotina de treinos envolvendo método, dedicação e repetição (Abreu, 2009; Levitin, 2008; Schellenberg, 2005), dessa maneira, infere-se que potencialize a capacidade de elaborar uma rotina de tarefas e de se concentrar nas mesmas. Estas habilidades tem o potencial de impactar direta e positivamente o desempenho escolar, de forma que estar no Projeto Guri foi associado por Gustavo à sua melhora em matemática.

Conforme se observa nos recortes abaixo, os entrevistados também referiram que o envolvimento com o Projeto Guri modificou as perspectivas que tinham acerca do futuro:

"Antes eu me via como uma menina que fazia o que tinha que fazer na escola, mas que não tinha uma coisa dela, que ela soubesse fazer. Agora, aqui, eu venho aqui e eu faço uma coisa que eu sei que sei. E eu tenho algo aqui que é meu e tenho algo a mais das pessoas que não sabem. Como se fosse uma coisa só minha. Poucas pessoas conseguem ter uma música que é delas e eu, agora, que eu toco, sinto que elas são minhas e antes eu não sentia assim."

(Viviana - 14 - 36, estudante de canto coral)

"Agora eu penso em outras coisas, penso em fazer faculdade, penso em coisas que só meus amigos pensavam. Antes eu só estudava, mas agora eu saio, ouço música. Antes eu era alguém que não tinha futuro, mas agora eu posso ser mais, não sei o que, mas posso ser mais do que aquela menininha."

(Tatiana - 17 - 46, estudante de viola)

Viviana acredita que "faz algo que sabe que sabe" [sic]. Para a jovem, ao executar uma música, sente que tem algo que é dela e de mais ninguém, ou seja, acredita que tem as capacidades necessárias para desempenhar uma tarefa que considera única e especial. $\mathrm{O}$ 
depoimento de Viviana evidencia um relacionamento muito pessoal com o fazer musical, de forma que se sente empoderada ao reconhecer suas habilidades. Esta compreensão do fazer musical se liga ao senso crítico e estético, que são habilidades apontadas por Abreu (2009) como importantes aspectos desenvolvidos pelo "El Sistema", atrelados à capacidade de reconhecer, produzir e buscar o belo. E, como pôde ser observado neste estudo, esses elementos também são valorizados no Projeto Guri.

Mais do que aprender a apreciar música, o Projeto Guri parece auxiliar em aspectos mais amplos do desenvolvimento dos estudantes. Tatiana refere que dentro do Polo ela é uma pessoa mais animada do que era antes de entrar no PEM, mas fora ainda possui as dificuldades de relacionamento que tinha no passado. Ainda assim, relata que hoje é uma pessoa que sai mais, que aprendeu a ser ela mesma, entendendo que agora pode "ser mais do que aquela menininha" [sic], inclusive com planos de ingressar na faculdade. Tatiana parece vislumbrar um futuro para si própria, e associa tais transformações ao fato de estar no PEM. A construção de Projetos de Vida parece ser outro efeito que o envolvimento com PEM possibilita. Neste contexto, Projeto de Vida pode ser entendido como:

\footnotetext{
“Aspirações, desejos de realizações, que se projetam para o futuro como uma visão antecipatória de acontecimentos, cuja base reside em uma realidade construída na interseção das relações que o sujeito estabelece com o mundo. É, portanto, constituído por um conjunto de aspectos que estruturam o campo psicossocial. A ideia de que o Projeto de Vida delineia-se na relação do sujeito com o mundo remete-nos à constituição do sujeito com a sociedade. As histórias de cada um certamente não seriam protagonizadas sem a presença do outro."
}

(Nascimento, 2006, p. 59)

A definição trazida pela autora coloca a construção do Projeto de Vida como ligado às vivências concretas do adolescente. Desta maneira, a definição de Nascimento (2006) e o futuro ambicionado por Tatiana indicam que o Projeto Guri exerceu influência direta no cotidiano de vida da estudante, sendo fator decisivo na construção de seu Projeto de Vida. Tendo em vista esta reflexão, o desenrolar da vida dos estudantes pode ser um dado importante para mensurar os impactos dos PEMs no desenvolvimento de seus egressos. 


\subsubsection{Envolvimento com música e desenvolvimento humano na perspectiva de profissionais e responsáveis legais}

Esta categoria reúne falas de profissionais e responsáveis legais sobre suas impressões acerca dos efeitos no desenvolvimento dos estudantes decorrentes do envolvimento no Projeto Guri.

'E a educação coletiva propicia ' $n$ ' habilidades como automonitoria do aluno até companheirismo. Eu sou prova disso, a música me disciplinou, eu era um menino da pá virada. As crianças desenvolviam muito o corpo, a psicomotricidade. Aí, as crianças desenvolvem um lado do cérebro que não trabalhavam e quando você dá esse 'upgrade' você é capaz de fazer mais habilidade. Essa é a importância do projeto de música, esse 'upgrade' ao saber controlar o corpo de maneira geral e isso faz com que ele aprenda com mais facilidade. Isso acontece e é escancarado. $O$ aluno que está estudando piano está preocupado com a postura, com o movimento dos dedos e do punho e ao mesmo tempo está ouvindo o instrumento e está lendo a partitura. Isso são muitas funções ao mesmo tempo."

(Roger, Supervisor Educacional)

"A música trabalha com regiões do cérebro e ela amplifica isso, e depois que você amplia você não reduz. A questão da atenção, da dedicação, da percepção rítmica, da percepção motora, praxia fina, lateralidade, tudo isso envolve o fazer musical. E a criança depois de passar por isso ela segue diferenciada, seja para fazer música ou não. São poucos os que vão para a música, mas a música está ali também."

(Francisco, Professor)

Para Roger e Francisco, o desenvolvimento de áreas cerebrais é apontado como consequência do envolvimento com a prática musical. Segundo eles, o desenvolvimento cerebral é algo que não tem volta, ou seja, após ter sido feito o "upgrade" [sic], o cérebro passa a funcionar de maneira diferente e isso gera ganhos para o resto da vida. $\mathrm{O}$ efeito do treino musical na estrutura do Sistema Nervoso já foi demonstrado por diversos estudos (Brown, Zatorre \& Penhune, 2015; Hyde et al., 2009; Schlaug, Norton, Overy \& Winner, 2005; Schlaug, 2015). Além disso, o processo descrito pelos educadores pode ser explicado pelo conceito da plasticidade cerebral (Muszkat, 2012). Desse modo, são observáveis os efeitos do envolvimento musical especificamente no cérebro, de forma que tal envolvimento possa ser associado a importantes aspectos do desenvolvimento. Para Bueno (2012), é necessário que os educadores estejam afinados com uma noção de desenvolvimento que 
integra aspectos psicológicos, biológicos e sociais. Estes aspectos ficam evidentes nas falas dos profissionais que destacaram o desenvolvimento do corpo e das habilidades relacionadas ao seu controle, tais como lateralidade, praxia fina e percepção motora. Os profissionais evidenciaram, ainda, uma compreensão de que os ganhos relativos ao controle sobre o corpo estão relacionados à maior facilidade para o processo de aprendizagem. Além de consequências corporais e do Sistema Nervoso destacadas por Roger e Francisco, outros profissionais e responsáveis legais também identificam efeitos do envolvimento com o Projeto Guri.

"Guri faz diferença na vida das famílias e das crianças e isso basta. (...) Música dá percepção de coisas que vão pra vida: coordenação motora, vivência emocional. Ensinar com excelência acarreta o desenvolvimento humano. O compromisso de ensinar com profissionalismo acarreta no comprometimento maior dos alunos."

(Maura, Supervisora Educacional)

“(...) E é claro que o Guri, que por trabalhar essa questão de formação, ele sabe que através da música a criança vai ter vários benefícios. Tanto na área da saúde, educacional, desenvolvimento, cognitivo (...). Autoestima, comportamento, relacionamento social mesmo."

(Priscila, Coordenadora de Polo)

"Assim, essa coisa do Projeto (Guri) de além de ser altamente positiva, porque música ajuda na personalidade da criança por estar se desenvolvendo. (...) Então é pela formação intelectual, moral."

(Mariana, avó de Camille - 13 - 10, estudante de flauta transversal)

"Eu percebo que, quando eu venho buscá-la, que o clima aqui é uma coisa diferenciada. Ela se soltou um pouco mais..."

(Mariana, avó de Camille - 13 - 10, estudante de flauta transversal)

"(Estar no PEM mudou) a timidez. Eles se soltaram. O Luiz era muito tímido e hoje em casa eu vejo que ele canta, vai treina. Fica treinando, foi muito bom."

(Joana, mãe de Luiz - 13 - 43, estudante de violino)

"Música ajudou no contato entre os filhos. Meu filho é bem hiperativo e acho que o trombone foi muito bom."

(Luciana, mãe Vitor Hugo - 13 - 10, estudante de trombone)

"É mais um pouquinho que aprende, é uma conquista a mais, um incentivo, uma motivação tanto para vir aqui quanto para o estudo, para a tarefa de casa."

(Giovana, mãe de Benjamin - 10 - 26, estudante de violoncelo) 
"Pedro Paulo está há mais tempo. Eu acho muito importante. A gente valoriza muito. A disciplina melhorou muito, o esperado da pediatra, está menos agitado. E eles gostam demais, estão gostando do instrumento. Ele teve dificuldade no início, mas agora está gostando. Menos estressado com a rotina. Esse é um momento só dele. Não sei se há uma relação, mas quando eles começaram aqui percebi que teve uma mudança muito grande na escola (se referindo ao comportamento dos filhos na escolha regular) e a gente sente também, porque a gente acredita muito na música e na educação. A gente percebe que tem um avanço muito grande."

(Luiza, mãe de Pedro Paulo - 11 - 24, estudante de viola e João Paulo - 8 - 12, estudante de iniciação musical)

Maura identifica que o envolvimento com a música acarreta consequências "que vão para a vida" [sic] tais como coordenação motora e vivência emocional. De acordo com Immordino-Yang e Damasio (2007), subjacente ao aprendizado ocorre um processamento emocional oculto, nomeado pelos autores de "leme emocional". Assim, quando educadores falham em prezar pelas emoções dos estudantes, falham em prezar pela força crítica dos estudantes no processo de aprendizagem. Dessa maneira, infere-se que a vivência emocional proporcionada por estar no Projeto Guri está relacionada ao objetivo principal de PEMs de desenvolvimento humano através da música.

Atuar sobre o desenvolvimento de pessoas é o objetivo principal do Projeto Guri e, nesse sentido, para Priscila, estar no PEM proporciona benefícios na saúde dos estudantes. Chanda e Levitin (2013) apontam efeitos positivos da música sobre o sistema imunológico e a regulação do humor, aspectos que se relacionam à fala da Coordenadora. Benefícios educacionais e cognitivos que a educação musical proporciona também foram identificados por Schellenberg (2005) e Moreno et al. (2011). Os estudos encontraram correlação positiva entre o treino musical e efeitos positivos na inteligência e funcionamento executivo dos participantes, aspectos apontados por Mariana, Giovana e Luiza.

As falas da Coordenadora e dos responsáveis legais evidenciam, ainda, uma compreensão de que o envolvimento com o PEM está associado à melhora da autoestima e a ganhos no âmbito dos relacionamentos interpessoais, reforçando, a partir da ótica dos profissionais, os apontamentos tratados em tópicos anteriores deste trabalho.

Os estudantes do PEM tiveram escores mais altos ao responderem a Escala de Autoestima de Rosenberg do que crianças e adolescentes que frequentavam as mesmas escolas regulares mas não frequentavam aulas de música. Numa avaliação de PEMs ingleses baseados na metodologia do "El Sistema", Lewis et al. (2011), através de entrevistas, 
identificaram impactos na autoestima dos estudantes. Para os autores, isso ocorre devido às performances (apresentações artísticas) que ocorrem frequentemente durante o envolvimento da criança nos PEMs, além da confiança gerada pela autorização de levarem instrumentos para casa com o objetivo de praticarem. A performance no Projeto Guri é estudada por Hikiji (2006b) e, para a autora, na e para a performance são construídas identidades, indicando resultados semelhantes aos apontados por Lewis et al. (2011).

Para Verni e Tardeli (2015), a autoestima está correlacionada ao desenvolvimento de Projetos de Vida e é neste desenvolvimento de projetos futuros que os PEMs focam sua atuação, tendo a perspectiva do desenvolvimento humano como transversal a todas as ações. Isso se relaciona a ideia de mudanças mais amplas que o envolvimento com PEM pode trazer, assim como nos seguintes trechos:

"Eu acho que essa oportunidade que as crianças tão tendo vão fazer adultos melhores, alguns vão se profissionalizar. A médio, longo prazo vão fazer uma diferença muito grande na vida de uma criança e do entorno também."

(Mariana, avó de Camille - 13 - 10, estudante de flauta transversal)

"(falando sobre os objetivos do Projeto Guri) é atender minimamente o desejo de aprender música, independente da classe social, independente de condição de saúde, deficiência ou não, é dar essa possibilidade. E através dessa possibilidade abrir outras possibilidades porque pode ser que seja uma coisa muito pontual ser músico, pode ser que aqui eu aprendi a viver em grupo, aprender a ter respeito, pode ser que aprendi a escutar música erudita, aprendi a diferença entre instrumentos. Pode ser do mais trivial até o que vai fazer esse aluno ser o ás da música. É isso, é dar caminho para outros caminhos, uma ponte, nem que seja "fiz Guri, foi legal, não é o que eu quero". Acho que esse é o objetivo e a continuidade."

(Kátia F., Supervisora de Desenvolvimento Social)

"Mas isso é o que queremos que a pessoa esteja aqui e carregue para a vida um pouco do que aprenderam com a gente."

(Bernardo, Supervisor Operacional)

As mudanças mais amplas apontadas por Mariana, Kátia F. e Bernardo são os Projetos de Vida que os estudantes podem gerar enquanto pessoas em desenvolvimento. O ensino musical realizado pelo Projeto Guri proporciona a criação de Projetos de Vida ligados, ou não, a música. Os impactos do estudo musical no desenvolvimento dos estudantes, percebidos pelos entrevistados, parecem afinados com aqueles identificados por Abreu (2009) referentes 
ao "El Sistema" e por estudos com PEMs em diferentes contextos (Creech et al. 2013), o que sugere, ainda, que a cooperação iniciada em 2015 entre o "El Sistema" e o Projeto Guri representa uma aproximação cujo objetivo é o aprimoramento de metas que já são consonantes. 



\section{Conclusões}

o objetivo do presente estudo é investigar os impactos de uma experiência de um Programa de Educação Musical sobre os aspectos psicológicos de seus estudantes, mais especificamente a autoestima, as habilidades sociais e o funcionamento executivo. Os testes psicológicos utilizados para mensurar cada construto foram, respectivamente, a Escala de Auto Estima de Rosenberg (EAR), a Matson Evaluation of Social Skills with Youngsters (MESSY) e o Teste de Stroop. O estudo aconteceu em um PEM e em duas escolas regulares, sendo uma particular e uma da rede pública de ensino. A coleta de dados foi feita com crianças e adolescentes divididas em três grupos: Grupo Iniciante (GI), Grupo Experiente (GE) e Grupo Controle (GC). Além da coleta de dados com uso de testes psicológicos, foram realizadas entrevistas semi-estruturadas com estudantes do PEM, responsáveis legais e profissionais do PEM. As entrevistas ampliaram a possibilidade de compreensão das análises dos testes psicológicos e, ainda, permitiram um melhor delineamento dos impactos causados pelo uso de metodologias coletivas de educação musical tanto sobre o desenvolvimento dos estudantes, quanto sobre o entorno e o próprio PEM.

De acordo com os resultados dos testes psicológicos, verificou-se que os estudantes do Projeto Guri possuem níveis mais elevados de autoestima e menores índices de solidão e ansiedade social (fator 4 da MESSY), corroborando os achados das entrevistas. Infere-se que o ambiente do PEM, por se organizar de maneira acolhedora a partir de contatos pró-sociais e com enfoque no trabalho em equipe e no ensino musical de qualidade (Abreu, 2009; Creech et al., 2013), desencadeia uma série de transformações pessoais nos estudantes, as quais também podem causar impactos no meio externo ao PEM. As entrevistas realizadas indicaram uma série de transformações que ocorreram devido ao envolvimento com o Projeto Guri, tais como mudanças no corpo, na forma de se relacionar com as pessoas e com o ambiente e, ainda, nas perspectivas de futuro, envolvendo a construção de Projetos de Vida. Dessa maneira, as entrevistas respaldaram as diferenças encontradas através das análises dos testes psicológicos, deixando-as com contornos mais sólidos.

Ainda no mesmo sentido, os efeitos indicados pela EAR e pelo fator 4 (Solidão/Ansiedade Social) da MESSY no nível pessoal-relacional, têm paralelos com substratos neurais que foram identificados nas entrevistas e encontram respaldo na literatura científica (Butman \& Allegri, 2001; Frewen et al., 2013; Jurado \& Rosselli, 2007; Northoff et al., 2006). A plasticidade cerebral consiste em mudanças adaptativas que ocorrem na estrutura 
e função do Sistema Nervoso em qualquer fase da ontogenia, como resultado de interações com o meio ambiente interno ou externo (Muszkat, 2012). Os resultados mostraram transformações na forma como os estudantes programam, verificam e regulam suas atividades. Assim, utilizando-se os conceitos de Luria (1984), pode-se inferir que ocorreram mudanças estruturais na forma como se organiza a terceira UF, o que implica em novas formas de interação entre as três UFs, uma vez que funcionam em concerto.

Os escores do Teste de Stroop e dos fatores 1 (Agressividade/Comportamento Antissocial), 2 (Habilidades Sociais/Assertividade) e 3 (Vaidade/Arrogância) da MESSY não apresentaram diferenças estatísticas significativas entre os grupos de participantes, o que pode sugerir certa homogeneidade entre as populações. Dessa forma, constatou-se a necessidade de outros controles experimentais como o uso de medições pré e pós intervenção e a ampliação dos instrumentais usados com o uso de mais de um teste psicológico para mensurar cada construto.

O estudo de Creech et al. (2013) pode servir de referência para a ampliação dos construtos estudados, visto que diversas consequências do envolvimento com a metodologia do "El Sistema" são identificadas pelos autores no desenvolvimento de crianças e adolescentes. Ainda assim, os estudos, na sua grande maioria, não utilizam instrumentos de mensuração quantitativos, de forma que seus resultados se restringem às impressões dos autores sobre os PEMs ou, ainda, ao que entrevistas sugerem sobre os impactos do envolvimento com os PEMs. Nesse sentido, o presente estudo representou uma inovação por utilizar testes psicológicos adaptados e padronizados para a população estudada, visando a mensuração dos fatores indicados por Abreu (2009) como influenciados pelo envolvimento com o "El Sistema". O uso da MESSY, especificamente, foi original visto que não foi encontrado nenhum estudo com essas características nos levantamentos realizados para a elaboração desta pesquisa. Segundo Bueno (2012), a psicologia possui papel importante no desenvolvimento de instrumental para auxiliar no desenvolvimento de indicadores dos efeitos que PEMs geram em comunidades e em indivíduos.

Com relação ao fato do Grupo Iniciante não se diferenciar do Grupo Experiente, podese cogitar que isto se deve aos critérios utilizados para formação dos grupos experimentais. Hipotetizou-se que estar envolvido com o Projeto Guri há até 12 meses pode significar uma vivência muito extensa no cotidiano deste PEM para que estes alunos fossem considerados como "iniciantes". As entrevistas corroboraram essa hipótese visto que estudantes com menos de 12 meses de matrícula relataram mudanças em seus comportamentos causadas pelo envolvimento com o PEM. 
Porém, não foram identificadas diferenças nas comparações realizadas entre os estudantes com menos de três meses de matrícula no PEM e os com mais de 36 meses de envolvimento com o mesmo, ainda assim, ressalta-se que os grupos desta comparação eram formados por poucos participantes o que não permitiu uma análise estatística mais robusta. Para futuros estudos, sugere-se que seja revisto o critério de tempo para considerar estudantes de PEMs como "iniciantes", reduzindo o critério de 12 meses utilizado nesta pesquisa.

O Projeto Guri é um PEM em constante mudança para se adequar ao cumprimento de sua missão de desenvolvimento humano. O maior investimento feito nos últimos anos na Diretoria de Desenvolvimento Social pode significar uma aproximação maior com o método proposto pelo "El Sistema", o qual tem como base de intervenção o tripé indivíduo-famíliacomunidade. A noção de intervenção integrada nessas três esferas parece ter sido desenvolvida recentemente no Projeto Guri, o que pode justificar a existência de dificuldades dos profissionais em entender o desenvolvimento social como estando atrelado ao musical, muito embora, alguns profissionais tenham se mostrado consonantes com a proposta. A atual aproximação do Projeto Guri com o "El Sistema" pode significar um avanço ainda maior neste sentido. Ainda assim, o PEM estudado tem desenvolvido metodologias de intervenção próprias, adaptadas às realidades em que suas atividades ocorrem o que configura um grande passo quando se objetiva formar pessoas e intervir em comunidade. Ressalta-se que diversos estudos com experiências de adaptação do "El Sistema" ao redor do mundo já apontam essa necessidade (Booth, 2009, 2013; Slevin \& Slevin, 2013).

As mudanças apontadas pelos testes e entrevistas relativas a aspectos individuais dos participantes, como na percepção do corpo e em habilidades específicas, parecem estar relacionadas a aspectos mais amplos do meio social em que o PEM está inserido, como escolas, residências e comunidades. Ainda podem ser inferidas novas configurações da organização do Sistema Nervoso referentes a mudanças comportamentais apresentadas pelos estudantes. Dessa maneira, o funcionamento do cérebro sócio-musical proposto por Bueno (2012) foi evidenciado pelos resultados do presente estudo na medida em que foi identificado o desenvolvimento integrado entre aspectos psicológicos, biológicos e sociais de crianças e adolescentes envolvidas com um Programa de Educação Musical com enfoque no resgate de populações em vulnerabilidade social. Esses dados oferecem elementos para um estudo sistemático da neurobiologia da educação Sócio-Musical (Bueno, 2012; Chanda \& Levitin, 2013; Luria, 1984). 



\section{Referências}

Abreu, J. A. (2009). Kids transformed by music. [Arquivo de Video]. Recuperado em 20 de dezembro de 2015, de http://www.ted.com/talks/jose_abreu_on_kids_transformed_by_music.html

Alain, C., Zendel, B. R., Hutka, S., \& Bidelman, G. M. (2014). Turning down the noise: the Benefit of musical training on the aging auditory brain. Hearing research, 308, 162173. doi: 10.1016/j.heares.2013.06.008

Allan, J. (2010). Arts and the in inclusive imagination: Socially engaged arts practices and Sistema Scotland. Journal of Social Inclusion, 1(2), 111-122. Recuperado em 20 de dezembro de 2015 ,

de http://www104.griffith.edu.au/index.php/inclusion/article/viewArticle/118

Allan, J., Moran, N., Duffy, C., \& Loening, G. (2010). Knowledge exchange with Sistema Scotland. Journal of education policy, 25(3), 335-347. doi: $10.1080 / 02680931003646196$

Associação Amigos do projeto Guri [AAPG]. (2014). Recuperado em 20 de dezembro de 2015, de http://www.projetoguri.org.br/

Associação Amigos do projeto Guri [AAPG]; Ipsus. (2013). Pesquisa de Avaliação de Impacto do Projeto Guri: Resultados 2011, 2012 e 2013. Recuperado em 20 de dezembro de 2015, de http://www.projetoguri.org.br/novosite/wpcontent/uploads/2014/06/ipsos_p2.pdf

Associação Amigos do projeto Guri [AAPG]. (2015). Relatório de Atividades 2014. Recuperado em 20 de dezembro de 2015, de http://www.projetoguri.org.br/novosite/wpcontent/uploads/2013/07/rel_atividades2014_p2a_menor.pdf

Ávila, R., Moscoso, M. A. A., Ribeiz, S., Arrais, J., Jaluul, O. \& Bottino, C. M. C. (2009). Influence of education and depressive symptoms on cognitive function in the elderly. International Psychogeriatrics, 21(3), 560 - 567. doi: 10.1017/S1041610209008928

Barros, P. M., \& Hazin, I. (2013). Avaliação das Funções Executivas na Infância: Revisão dos Conceitos e Instrumentos. Psicologia em Pesquisa, 7(1), 13-22. Recuperado em 20 de dezembro de 2015, de http://www.ufjf.br/psicologiaempesquisa/files/2013/08/02v7n1.pdf

Baumeister, R. F., Campbell, J. D., Krueger, J. I., \& Vohs, K. D. (2003). Does high selfesteem cause better performance, interpersonal success, happiness, or healthier lifestyles?. Psychological science in the public interest, 4(1), 1-44. doi: 10.1111/15291006.01431

Blakemore, S. J., \& Frith, U. (2005). The learning brain: Lessons for education. Malden: Blackwell publishing. 
Bogdan, R. \& Biklen, S. (1994). Investigação Qualitativa em Educação: Uma introdução à teoria e aos métodos. Porto: Porto Editora.

Booth, E. (2013). Fundamental Elements of Venezuela's El Sistema: Which Inform and Guide El Sistema-inspired Programs. Philarmônica de Los Angeles EUA. Recuperado em 20 de dezembro de 2015, de http://www.laphil.com/sites/default/files/media/pdfs/shared/education/yola/el_sis_fund amentals_jan_2013.pdf

Booth, E. (2009). Thoughts on Seeing El Sistema. Teaching Artist Journal, 7(2), 75-84. doi: $10.1080 / 15411790902762456$

Brown R. M., Zatorre R. J., Penhune V. B. (2015). Expert music performance: cognitive, neural, and developmental bases. Progress in Brain Research. 217, 57-86. doi: 10.1016/bs.pbr.2014.11.021

Bueno, J. L. O. (1997). Corpo Consciência e Crítica. Psicologia Reflexão e Crítica, 10(1), 147-154. doi: 10.1590/S0102-79721997000100010

Bueno, J. L. O. (2012). Neurobiologia da educação Sócio-Musical. (Relatório Capes Saint Hilarie/2012), Ribeirão Preto, SP, Faculdade de Filosofia Ciências e Letras de Ribeirão Preto, Universidade de São Paulo.

Butman, J., \& Allegri, R. F. (2001). A cognição social e o córtex cerebral. Psicologia: reflexão e crítica, 14(2), 275-279. doi: 10.1590/S0102-79722001000200003

Castro, S. L., Cunha, L. S. \& Martins, L. (2000). Teste Stroop Neuropsicológico em Português. Recuperado em 20 de dezembro de 2015, de http://www.fpce.up.pt/labfala [2014, 05, 02].

Chanda, M. L., \& Levitin, D. J. (2013). The neurochemistry of music. Trends in cognitive sciences, 17(4), 179-193. doi: 10.1016/j.tics.2013.02.007

Cline, D. E. (2012). Community Music Education Partnerships For Social Change: Six Unique Adaptations Of El Sistema In The United States Of America. Dissertação de mestrado. University of Cincinnati, Cincinnati, Ohio, EUA.

Creech, A., Gonzalez-Moreno, P. \& Waitman, G. (2013). El Sistema and Sistem-Inspired Programmes: A Literature Review of research, evaluation, and critical debates. San Diego: Sistema Global.

Del Prette, Z., \& Del Prette, A. (1999). Psicologia das habilidades sociais: Terapia e educação. Petrópolis: Vozes.

Duncan, M. T. (2006). Obtenção de dados normativos para desempenho no teste de Stroop num grupo de estudantes do ensino fundamental em Niterói. Jornal Brasileiro de Psiquiatria, 55(1), 42-8. Recuperado em 20 de dezembro de 2015, de http://www.scielo.br/pdf/jbpsiq/v55n1/v55n1a06.pdf 
Freire, P. (2003). Pedagogia do Oprimido. 36 ${ }^{\mathrm{a}}$ Ed. Rio de Janeiro: Edições Paz e Terra.

Freire, T., \& Tavares, D. (2011). Influência da autoestima, da regulação emocional e do gênero no bem-estar subjetivo e psicológico de adolescentes. Revista de Psiquiatria Clínica, 38(5), 184-188. Recuperado em 20 de dezembro de 2015, de http://www.scielo.br/pdf/rpc/v38n5/a03v38n5.pdf

Frewen, P. A., Lundberg, E., Brimson-Théberge, M., \& Théberge, J. (2013). Neuroimaging self-esteem: a fMRI study of individual differences in women. Social cognitive and affective neuroscience, 8(5), 546-555. doi: 10.1093/scan/nss032

Fundácion Musical Simón Bolívar [FundaMusical]. (s.d.). Recuperado em 20 de dezembro de 2015, de http://fundamusical.org.ve/

Golçalves, J. \& Neto, F. (2013). Influência da frequência de uma Universidade Sénior no nível de solidão, autoestima e redes de suporte social. Revista Eletrônica de Psicologia, Educação e Saúde, 3(1), 69-92. Recuperado em 20 de dezembro de 2015, de https://artes.porto.ucp.pt/sites/default/files/files/FEP/docs/Temas_em_Psicologia_do_ Envelhecimento_Vol_I.pdf\#page=72

Govias, J. A. (2011). The Five Fundamentals of El Sistema. Canadian Music Educator. 53(1), 21-23. Recuperado em 20 de dezembro de 2015, de https://jonathangovias.files.wordpress.com/2012/09/govias-five-fundamentals-of-elsistema.pdf

Hallam, S. (2010). The power of music: its impact on the intellectual, social and personal development of children and young people. International Journal of Music Education, 28(3), 269-289. doi: 10.1177/0255761410370658

Hargreaves, D. J., \& North, A. C. (2005). The social psychology of music. New York: Oxford University Press.

Hikiji, R. S. G. (2003a). Microfone, Senhora. [NTSC, cor, 16 min]. São Paulo: LISA/FAPESP.

Hikiji, R. S. G. (2003b). Prelúdio. [NTSC, cor, 13 min]. São Paulo: LISA/FAPESP.

Hikiji, R. S. G. (2005). Etnografia da performance musical: identidade, alteridade e transformação. Horizontes Antropológicos, 11(24), 155-184. doi: 10.1590/S010471832005000200008

Hikiji, R. S. G. (2006a). Música para matar o tempo intervalo, suspensão e imersão. Mana, 12(1), 151-178. doi: 10.1590/S0104-93132006000100006

Hikiji, R. S. G. (2006b). A música e o risco: etnografia da performance de crianças e jovens participantes de um projeto social de ensino musical. São Paulo: EDUSP.

Hutz, C. S., \& Zanon, C. (2011). Revisão da adaptação, validação e normatização da escala de autoestima de Rosenberg. Avaliação Psicológica, 10(1), 41-49. Disponível em 
http://pepsic.bvsalud.org/scielo.php?pid=S1677-

$04712011000100005 \&$ script $=$ sci_arttext

Hyde, K. L., Lerch, J., Norton, A., Forgeard, M., Winner, E., Evans, A. C., \& Schlaug, G. (2009). Musical training shapes structural brain development. The Journal of Neuroscience, 29(10), 3019-3025. doi: 10.1523/JNEUROSCI.5118-08.2009

Ilari, B. (2005). A música e o desenvolvimento da mente no início da vida: investigação, fatos e mitos. Revista eletrônica de musicologia, 9. Recuperado em 20 de dezembro de 2015, de http://www.rem.ufpr.br/_REM/REMv9-1/ilari.html

Immordino-Yang, M. H., \& Damasio, A. (2007). We feel, therefore we learn: The relevance of affective and social neuroscience to education. Mind, Brain, and Education, 1(1), 310. doi: 10.1111/j.1751-228X.2007.00004.x

Jurado, M. B., Rosseli, M. (2007). The Elusive Nature of Executive Functions: A Review of Our Current Understading. Neurophychological Review, 17, 213-233. doi: $10.1007 / \mathrm{s} 11065-007-9040-\mathrm{z}$

Klein, M., Adda, C. C., Miotto, E. C., Cristina, M., Lucia, S. \& Scaff, M. (2010) O Paradigma Stroop em uma Amostra de Idoso Brasileiro. Psicologia Hospitalar, 8(1), 93-112. Recuperado em 20 de dezembro de 2015, de http://pepsic.bvsalud.org/scielo.php?pid=S1677$74092010000100007 \&$ script=sci_arttext.

Levitin, D. J. (2008). The world in six songs: How the musical brain created human nature. Nova York: Penguin Group.

Lewis, K., Demie, F., \& Rogers, L. (2011). In Harmony Lambeth: An Evaluation. London: Lambeth Children and Young People's Service with the Institute of Education, University of London.

Lopes, V. \& Maia, J. (2000). Períodos críticos ou sensíveis: revisitar um tema polêmico à luz da investigação empírica. Revista Paulista de Educação Física, 14(2), 128-140. Recuperado em 20 de dezembro de 2015, de http://citrus.uspnet.usp.br/eef/uploads/arquivo/v14\%20n2\%20artigo3.pdf

Luria, A. R. (1984). Fundamentos de neuropsicologia. Rio de Janeiro: Livros Técnicos e Científicos; São Paulo: Editora da Universidade de São Paulo.

Majno, M. (2012). From the model of El Sistema in Venezuela to current applications: learning and integration through collective music education. Annals of the New York Academy of Sciences, 1252(1), 56-64. doi: 10.1111/j.1749-6632.2012.06498.x

Matson, J. L., Esveldt-Dawson, K., \& Kazdin, A. (1983). Validation of methods for assessing social skills in children. Journal of Clinical Child Psychology, 12, 174-180. doi: $10.1080 / 15374418309533127$ 
Ministério da Saúde. (2012). Diretrizes e normas regulamentadoras de pesquisa envolvendo seres humanos. Resolução no 466/12 do Conselho Nacional de Saúde. Brasília.

Moreno, S., Bialystok, E., Barac, R., Schellenberg, E. G., Cepeda, N. J., \& Chau, T. (2011). Short-term music training enhances verbal intelligence and executive function. Psychological Science, 22(11), 1425-1433. doi: 10.1177/0956797611416999

Muszkat, M. (2012) Música, Neurociência e desenvolvimento humano. In G . Jordão, R. Allucci, S. Molina \& A. Terahata. Ministério de Cultura e Vale: A música na escola. São Paulo: Allucci \& Associados Comunicações.

Nascimento, I. P. (2006). Projeto de vida de adolescentes do ensino médio: um estudo psicossocial sobre suas representações. Imaginário, 12(12), 55-80. Recuperado em 20 de dezembro de 2015, de http://pepsic.bvsalud.org/scielo.php?script=sci_arttext\&pid=S1413666X2006000100004

Northoff, G., Heinzel, A., de Greck, M., Bermpohl, F., Dobrowolny, H., \& Panksepp, J. (2006). Self-referential processing in our brain - a meta-analysis of imaging studies on the self. Neuroimage, 31(1), 440-457. doi:10.1016/j.neuroimage.2005.12.002

Peretz, I., \& Zatorre, R. J. (2005). Brain organization for music processing. Annual Review of Psychology, 56, 89-114. doi: 10.1146/annurev.psych.56.091103.070225

Poloni, N. B. (2012). NEOJIBÁ, Os toques brasileiros na experiência musical e sociocultural venezuelana. Trabalho de Conclusão de Curso de Pós-Graduação em Gestão de Projetos Culturais e Organização de Eventos. Escola de Comunicação e Artes, Universidade de São Paulo, São Paulo. Recuperado em 20 de dezembro de 2015, de http://200.144.182.130/celacc/sites/default/files/media/tcc/402-1145-1-PB.pdf

Purves, D., Augustine, G. J., Fitzpatrick, D., Katz, L. C., LaMatia, A. S., McNamara, J. O. \& Williams, S. M. (2005). Neurociências. Porto Alegre: Artmed.

Ramos, D., Bueno, J. L. O. \& Bigand, E. (2011). Manipulating Greek musical modes and tempo affects perceived musical emotion in musicians and non-musicians, Brazilian Journal of Medical and Biological Research, 44, 165-172. doi: 10.1590/S0100879X2010007500148

Rauschecker, J. P. (2005). Neural encoding and retrieval of sound sequences. Annals of the New York Academy of Sciences, 1060(1), 125-135. doi: 10.1196/annals.1360.009

Rosenberg, M. (1965). Society and the adolescent self-image. New Jersey: Princiton University press.

Rubin, K. H., Dwyer, K. M., Booth-LaForce, C., Kim, A. H., Burgess, K. B., \& RoseKrasnor, L. (2004). Attachment, friendship, and psychosocial functioning in early adolescence. The Journal of early adolescence, 24(4), 326-356. doi: $10.1177 / 0272431604268530$ 
Santos, P. J. (2008). Validação da Rosenberg Self-esteem Scale numa amostra de estudantes do ensino superior. In A. P. Noronha, C. Machado, L. Almeida, M. Golçalves, S. Martins \& V. Ramalho. Avaliação Psicológica: Formas e contextos. Braga: Psiquilibrios Edições.

Schaeffer, C. M., Petras, H., Ialongo, N., Poduska, J., \& Kellam, S. (2003). Modeling growth in boys' aggressive behavior across elementary school: links to later criminal involvement, conduct disorder, and antisocial personality disorder. Developmental psychology, 39(6), 1020. doi: 10.1037/0012-1649.39.6.1020

Schlaug, G., Norton, A., Overy, K., Winner, E. 2005. Effects of music training on the child's brain and cognitive development. Annals of the New York Academy of Sciences, 1060(1), 219-230. doi: 10.1196/annals.1360.015

Schlaug, G. 2015. Musicians and music making as a model for the study of brain plasticity. Progress in Brain Research, 217, 37-55. doi: 10.1016/bs.pbr.2014.11.020

Schellenberg, E. G. (2005). Music and cognitive abilities. Current Directions in Psychological Science, 14(6), 317-320. doi: 10.1111/j.0963-7214.2005.00389.x

Schellenberg EG. (2006). Long-term positive associations between music lessons and IQ. Journal of Educational Psychology. 98(2) 457-468. doi: 10.1037/0022-0663.98.2.457

Schellenberg, E. G., Corrigall, K. A. Dys, S. P. \& Malti, T. (2015). Group Music Training and Children's Prosocial Skills. Plos One 10(10), 1-14. doi:10.1371/journal.pone.0141449

Shoemaker, A. H. (2012). The Pedagogy of Becoming: Identity Formation through the Baltimore Symphony Orchestra's OrchKids and Venezuela's El Sistema. Tese de doutorado. University of North Carolina, North Carolina, EUA.

Slevin, M., \& Slevin, P. (2013). Psychoanalysis and El Sistema: Human Development through Music. International Journal of Applied Psychoanalytic Studies, 10(2), 132140. doi: 10.1002/aps.1355

Sloboda, J. A. (1985). The Music Mind: The cognitive psychology of music. New York: Oxford University Press.

Storr, A. (1992). Music and the mind. New York: Ballantine Books.

Swanwick, K. (2003). Ensinando música musicalmente. São Paulo: Moderna.

Teodoro, M. L. M., Käppler, K. C., Rodrigues, J. L., de Freitas, P. M. \& Haase, V. G. (2005). The Matson Evaluation of Social Skills with Youngsters (MESSY) and its adaptation for Brazilian children and adolescentes. Interamerican Journal of Psychology, 39, 230-246. doi: 10.1016/S0191-8869(96)00166-3

Trehub, S. E. (2003). The developmental origins of musicality. Nature neuroscience, 6(7), 669-673. doi: 10.1038/nn1084 
Turner, H. A., Shattuck, A., Finkelhor, D., \& Hamby, S. (2015). Effects of poly-victimization on adolescent social support, self-concept, and psychological distress. Journal of interpersonal violence. doi: 10.1177/0886260515586376.

Uy, M. S. (2012). Venezuela's National Music Education Program El Sistema: Its Interactions with Society and Its Participants' Engagement in Praxis. Music and Arts in Action, 4(1), 5-21. Recuperado em 20 de dezembro de 2015, de http://musicandartsinaction.net/index.php/maia/article/view/elsistema

Verni, P. J. \& Tardeli, D. D. A. (2015). Autoestima e projeto de vida na adolescência. 41 st Associations For Moral Education Conference. Recuperado em 20 de dezembro de 2015, de http://ame2015.net/wp-content/uploads/2015/11/Priscila_VerniAUTOESTIMA-E-PROJETO-DE-VIDA-NA-ADOLESCE_NCIA.pdf

Veronezi, R. J. B., Damasceno, B. P., \& Fernandes, Y. B. (2005). Funções psicológicas superiores: origem social e natureza mediada. Revista de Ciências Médicas, 14(6), 537-541. Recuperado em 20 de dezembro, de http://periodicos.puccampinas.edu.br/seer/index.php/cienciasmedicas/article/view/1147

Vigotski, L. S. (1995). Historia del desarrollo de las funciones psíquicas superiores. In LS Vigotski. Problemas del desarrollo de la psique. (L. Kuper, Trad, pp. 09-340). Madrid: Visor Dist.

Zampronha, M. D. L. S. (2007). Da música, seus usos e recursos. São Paulo: Editora UNESP. 
1ก 



\section{Apêndices}

\section{Apêndice 1 - Termo de Consentimento Livre e Esclarecido (Estudantes) TERMO DE CONSENTIMENTO LIVRE E ESCLARECIDO ESTUDANTES}

$\mathrm{O}(\mathrm{a})$

está sendo convidado(a) para participar voluntariamente do estudo intitulado "O Cérebro Sócio-Musical: estudo de uma experiência de educação musical", a ser realizado pelo psicólogo mestrando Alexandre A. Mateus Moisés, orientado pelo Prof. Dr. José Lino Oliveira Bueno, docente da Faculdade de Filosofia Ciências e Letras de Ribeirão Preto da Universidade de São Paulo (FFCLRP - USP).

O objetivo do experimento é verificar o efeito do treino musical no desenvolvimento de crianças e adolescentes de um Programa de Educação Musical. Ela justifica-se, pois, com ela, pretende-se ampliar o entendimento dos efeitos do treino musical como ferramenta de intervenção social.

Os benefícios esperados em consequência da pesquisa são o auxílio na implementação e avaliação de Programas de Educação Musical.

O experimento terá duração de aproximadamente 01 hora. Para isso serão utilizados instrumentos psicológicos e realizada uma entrevista. A entrevista será áudio gravada com o seu consentimento e do(a) participante e o conteúdo da mesma será transcrito para que seja utilizado nas futuras publicações dos resultados deste estudo. A gravação será arquivada em sigilo até a publicação da pesquisa, quando a gravação será destruída. O procedimento acontecerá nas dependências do Programa de Educação Musical que o(a) voluntário(a) está matriculado(a).

Caso você permita sua participação como voluntário(a) nesse experimento, saiba que é livre para interromper a sua participação a qualquer momento durante o procedimento experimental, e se assim o fizer, não haverá prejuízos de qualquer ordem em função desta decisão.

O experimento ao qual será submetido não apresenta nenhum risco previsível para sua saúde física ou mental.

Após a participação, é garantido a você e a ele(a)o recebimento de esclarecimentos atualizados sobre qualquer etapa deste trabalho, durante ou após o curso da pesquisa.

Além disso, garante-se a todos(as) os participantes o sigilo quanto a sua identificação. Também é garantida total preservação de sua privacidade em quaisquer tipos de dados que sejam fornecidos ao longo da pesquisa.

A participação nesta pesquisa não acarretará nenhum gasto financeiro, e, portanto, não está previsto reembolso de qualquer natureza.

Este Termo de Consentimento foi elaborado em duas vias, sendo que uma das cópias ficará com você, enquanto a outra será arquivada pelo pesquisador. 
Qualquer dúvida com relação a participação poderá ser esclarecida antes, durante e após a realização do estudo, tanto com o pesquisador quanto com o professor que orienta este estudo, Prof. Dr. José Lino Oliveira Bueno.

Obrigado pela sua atenção e colaboração!

$\mathrm{Eu}$ autorizo participar voluntariamente do

presente estudo.

Ribeirão Preto, de de 2014.

\section{ASSINATURA DO RESPONSÁVEL}

Alexandre Mateus Moisés

Mestrando

(16) 99208-2355

alexandremateusmoises@usp.br
Prof. Dr. José Lino Oliveira Bueno

Docente responsável

(16) 3602-3800

jldobuen@ffclrp.usp.br 


\section{Apêndice 2 - Termo de Consentimento Livre e Esclarecido (Responsáveis Legais e \\ Professores)}

\section{TERMO DE CONSENTIMENTO LIVRE E ESCLARECIDO RESPONSÁVEIS E PROFESSORES}

Você está sendo convidado para participar voluntariamente do estudo intitulado "O Cérebro Sócio-Musical: estudo de uma experiência de educação musical”, a ser realizado pelo psicólogo mestrando Alexandre A. Mateus Moisés, orientado pelo Prof. Dr. José Lino Oliveira Bueno, docente da Faculdade de Filosofia Ciências e Letras de Ribeirão Preto da Universidade de São Paulo (FFCLRP - USP).

O objetivo do experimento é verificar o efeito do treino musical no desenvolvimento de crianças e adolescentes de um Programa de Educação Musical. Ela justifica-se, pois, com ela, pretende-se ampliar o entendimento dos efeitos do treino musical como ferramenta de intervenção social.

Os benefícios esperados em consequência da pesquisa são o auxílio na implementação e avaliação de Programas de Educação Musical.

O experimento terá duração de aproximadamente 30 minutos. Para isso será realizada uma entrevista que será áudiogravada com o seu consentimento e o conteúdo da mesma será transcrito para que seja utilizado nas futuras publicações dos resultados deste estudo. A gravação será arquivada em sigilo até a publicação da pesquisa, quando a gravação será destruída. A entrevista acontecerá nas dependências do Programa de Educação Musical.

Caso você concorde em participar como voluntário neste experimento, saiba que é livre para interromper sua participação a qualquer momento durante o procedimento experimental, e se assim o fizer, não haverá prejuízos de qualquer ordem em função desta decisão.

O experimento ao qual você será submetido não apresenta nenhum risco previsível à sua saúde física ou mental.

Após a sua participação, é garantido a você o recebimento de esclarecimentos atualizados sobre qualquer etapa deste trabalho, durante ou após o curso da pesquisa.

Além disso, garante-se a todos os participantes o sigilo quanto a sua identificação. Também é garantida total preservação de sua privacidade em quaisquer tipos de dados que sejam fornecidos ao longo da pesquisa.

A sua participação nesta pesquisa não acarretará nenhum gasto financeiro, e, portanto, não está previsto reembolso financeiro de qualquer natureza.

Este Termo de Consentimento foi elaborado em duas vias, sendo que uma das cópias ficará com você, enquanto a outra será arquivada pelo pesquisador. 
Qualquer dúvida com relação a sua participação poderá ser esclarecida antes, durante e após a realização do estudo, tanto com o pesquisador quanto com o professor que orienta este estudo, Prof. Dr. José Lino Oliveira Bueno.

Obrigado pela sua atenção e colaboração!

$\mathrm{Eu}$, aceito participar voluntariamente do presente estudo.

Ribeirão Preto, de de 2014.

\section{ASSINATURA DO PARTICIPANTE}

Alexandre Mateus Moisés

Mestrando

(16) 99208-2355

alexandremateusmoises@usp.br
Prof. Dr. José Lino Oliveira Bueno Docente responsável

(16) 3602-3800

jldobuen@ffclrp.usp.br 


\section{Apêndice 3 - Termo de Assentimento}

\section{TERMO DE ASSENTIMENTO}

Você está sendo convidado a participar de um estudo sobre os efeitos do treino musical no desenvolvimento. O título do projeto é "O Cérebro Sócio-Musical: estudo de uma experiência de educação musical”, a ser realizado pelo psicólogo mestrando Alexandre A. Mateus Moisés, orientado pelo Prof. Dr. José Lino Oliveira Bueno, docente da Faculdade de Filosofia Ciências e Letras de Ribeirão Preto da Universidade de São Paulo (FFCLRP - USP).

O objetivo da pesquisa é verificar o efeito do treino musical no desenvolvimento de crianças e adolescentes de um Programa de Educação Musical. Ela justifica-se, pois, com ela, pretende-se ampliar o entendimento dos efeitos do treino musical como ferramenta de intervenção social.

Os benefícios esperados em consequência da pesquisa são o auxílio na implementação e avaliação de Programas de Educação Musical.

O experimento terá duração de aproximadamente 01 hora e será realizado em uma sala especialmente preparada de sua escola. Na sala, o pesquisador indicará as atividades que você deverá realizar. Tais atividades não vão the causar qualquer incômodo previsível. Serão feitas algumas perguntas que serão audiogravadas e a gravação será arquivada em sigilo até a publicação da pesquisa, quando a gravação será destruída.

Caso você concorde em prosseguir como voluntário nessa pesquisa, você é livre para interromper sua participação a qualquer momento, e se assim o fizer, não haverá prejuízos em função desta decisão. Da mesma forma, você poderá se recusar a responder perguntas que não queira.

Depois da sua participação você poderá fazer perguntas a respeito do que foi feito.

Você não será identificado e também é garantido que seu nome não aparecerá em quaisquer tipos de dados que sejam fornecidos ao longo da pesquisa.

A sua participação nesta pesquisa não acarretará nenhum gasto financeiro, e, portanto, não está previsto reembolso de qualquer natureza.

Este Termo de Aceite tem duas vias, sendo que uma das cópias ficará com você, enquanto a outra será arquivada pelo pesquisador.

Caso você concorde em participar voluntariamente desta pesquisa, de acordo com a proposta acima apresentada, por favor, manifeste sua concordância assinando este Termo.

Qualquer dúvida também poderá ser respondida pelo professor que orienta a pesquisa, Prof. Dr. José Lino Oliveira Bueno.

Obrigado pela sua atenção e colaboração! 
$\mathrm{Eu}$,

aceito

participar voluntariamente do presente estudo.

Ribeirão Preto, de de 2014.

\section{ASSINATURA DO PARTICIPANTE}

Alexandre Mateus Moisés Mestrando

(16) 99208-2355

alexandremateusmoises@usp.br
Prof. Dr. José Lino Oliveira Bueno

Docente responsável

(16) 3602-3800

jldobuen@ffclrp.usp.br 


\section{Apêndice 4 - Roteiro de entrevista aos estudantes}

\section{Nome:}

Idade:

\section{Questões a serem abordadas:}

Escola que estuda:

Há quanto tempo estuda música?

Há quanto tempo está no projeto?

Já teve alguma experiência anterior com música?

Por que estuda música?

O que a música representa em sua vida?

O que aprendeu no projeto (além da música)?

O que mais gosta no projeto?

O que menos gosta no projeto?

O que mudaria no projeto?

Você acha que o projeto interfere ou interferiu na sua vida? Se sim, em quais aspectos?

Como você se descreveria para uma pessoa desconhecida?

Você acha que o projeto exerce alguma influência na forma como você se vê? 
Apêndice 5 - Roteiro de entrevista aos responsáveis legais

Nome:

Idade: Ocupação:

\section{Questões a serem abordadas:}

Ocupação:

Quantos filhos ou dependentes?

Qual a idade e o que fazem?

Quais as experiências anteriores da família (pais, tios, primos) com a música?

Por que matriculou ou permitiu que o dependente frequentasse as aulas de música do projeto?

Como você avalia a vivência do(a) nome do estudante no projeto?

Notou diferenças desde seu ingresso no projeto?

Como você avalia a sua participação no projeto? Poderia ser diferente? Gostaria de participar mais? 


\section{Apêndice 6 - Roteiro de entrevista aos professores}

\section{Nome:}

\section{Idade:}

\section{Questões a serem abordadas:}

Desde quando a música está em sua vida?

Desde quando está no projeto?

O que o levou a se envolver com a música e o projeto?

Como avalia sua experiência no projeto?

Para você, quais os objetivos do projeto?

O projeto consegue alcançar esses objetivos?

Quais seus objetivos em suas aulas?

Você consegue alcançar esses objetivos?

Você já deu aulas em outros locais? Se sim, você nota diferenças entre o projeto e os outros locais?

Você acha que a atuação do projeto exerce influências na comunidade?

Quão próximo da comunidade você acha que o projeto está?

Você nota alguma diferença nos alunos ou na comunidade para além da habilidade musical dos alunos? 




\section{Anexos}

\section{Anexo 1 - Carta de manifestação de concordância - Projeto Guri}

Itmo Sr.

José Lino Oliveira Bueno

Professor Titular em Psicobiologia

Departamento de Psicologia - FFCLRP

Prezado Professor

É com grande satisfaçấo que autorizamos o pedido para que o psicólogo Alexandre Mateus Moisés realize pesquisa de mestrado junto ao Projeto Guri, pois acreditamos que a Universidade de São Paulo, através desta pesquisa, terá muito a acrescentar à nossa prática pedagógica.

Aguardaremos ansiosos pelos resultados, e aproveitamos a oportunidade para reiterar nossos protestos de estima e consideração.

Atenciosamente;

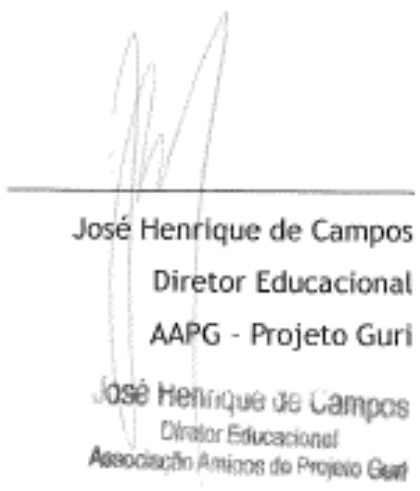

Amigos do Guri - Av, Francisco Matarazzo, 682 - Água Branca - São Paulo - SP - 05001-000 
Anexo 2 - Carta de manifestação de concordância - Escola Estadual Dr. Guimarães Junior

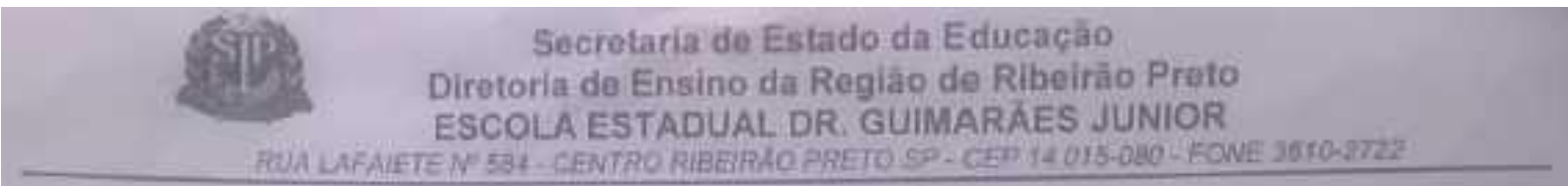

Pibaifato Preto, 09 de abril det 2015

$\operatorname{limo}$

José Lino Olivelra Buero.

Professor Titular em Psicobiologia

Departamento de Psicoiogia - FFCLAP

Prezado Professor;

Autorizo a estudante Alexandre Mateus Moises que desenvaive o projeto de mestrado Intituiado "O Cérebro Sócio-Musical Estudo de Uma Experiència de Educaça Musical" sua orientaçāo a realizat a coleta dé dados de seu mestradó nas dependencias de Escola Eatadual Doutor Guimaräes funior

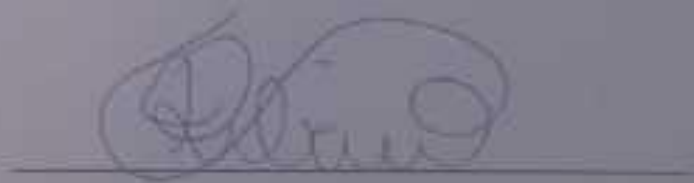


Anexo 3 - Carta de manifestação de concordância - Colégio Brasil

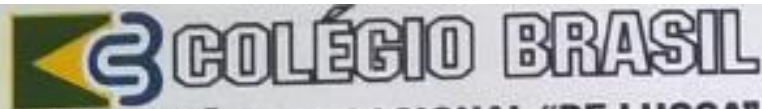 ASSOCIAÇĂO EDUCACIONAL "DE LUCCA"}

Ribeirāo Preto, 31 de agosto de 2015.

Ilmo. Sr.

José Lino Oliveira Bueno

Professor Titular em Psicobiologia

Departamento de Psicologia - FFCLRP

Prezado Professos:

Autorizo o estudante Alexandre Mateus Moisés que desenvolve o projeto de mestrado intitulado "O Cérebro Sócio-Musical: Estudo de uma Experiência de Educaçăo Musical" sua orientação a realizar a coleta de dados de seu mestrado nas dependèncias do Colégio Brasil.

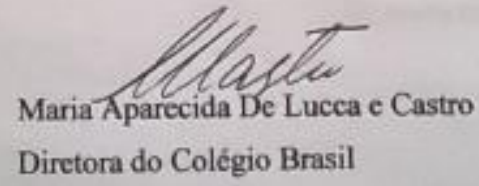

Rua Américo Brasiliense, 925 - Fone / Fax: (16) 3625-3546 - Cep: 14015-050 - Ribeirão Preto - SP Reconhecida pela Portaria C.E.I. De 09/01/1981 - Publicado D. O. E. 10/01/1981 


\section{Anexo 4 - Escala de Autoestima de Rosenberg}

Escala de Autoestima de Rosenberg

Leia cada frase com atenção e faça um círculo em torno da opção mais adequada

1. Eu sinto que sou uma pessoa de valor, no mínimo, tanto quanto as outras pessoas.

(1) Discordo Totalmente (2) Discordo (3) Concordo (4) Concordo Totalmente

2. Eu acho que eu tenho várias boas qualidades.

(1) Discordo Totalmente (2) Discordo (3) Concordo (4) Concordo Totalmente

3. Levando tudo em conta, eu penso que eu sou um fracasso.

(1) Discordo Totalmente (2) Discordo (3) Concordo (4) Concordo Totalmente

4. Eu acho que sou capaz de fazer as coisas tão bem quanto a maioria das pessoas.

(1) Discordo Totalmente (2) Discordo (3) Concordo (4) Concordo Totalmente

5. Eu acho que eu não tenho muito do que me orgulhar.

(1) Discordo Totalmente (2) Discordo (3) Concordo (4) Concordo Totalmente

6. Eu tenho uma atitude positiva com relação a mim mesmo.

(1) Discordo Totalmente (2) Discordo (3) Concordo (4) Concordo Totalmente

7. No conjunto, eu estou satisfeito comigo.

(1) Discordo Totalmente (2) Discordo (3) Concordo (4) Concordo Totalmente

8. Eu gostaria de poder ter mais respeito por mim mesmo.

(1) Discordo Totalmente (2) Discordo (3) Concordo (4) Concordo Totalmente

9. Às vezes eu me sinto inútil.

(1) Discordo Totalmente (2) Discordo (3) Concordo (4) Concordo Totalmente

10. Às vezes eu acho que não presto para nada.

(1) Discordo Totalmente (2) Discordo (3) Concordo (4) Concordo Totalmente

Observação: Os itens 3, 5, 8, 9 e 10 devem ser invertidos para calcular a soma dos pontos. 
Nome:

Sexo:

Idade:

Escolaridade:

Data:

Gostaríamos de saber um pouco sobre você e como você é / ou age na maioria das vezes. Para cada frase que virá abaixo, você deverá marcar apenas uma opção como resposta, devendo escolher um dos números que melhor representa o quanto você concorda com o que esta frase diz sobre você. Lembre-se de que não existem respostas certas ou erradas.

Por favor, marque as respostas dizendo como você é na maior parte do tempo!

Obrigado!

01. Eu faço as outras pessoas rirem.
(1) (2) (3) (4) ( 5 )

02. Eu ameaço as pessoas ou ajo como um valentão.

\section{(1) (2) (3) (4) ( 5 )}

03. Eu fico com raiva facilmente.
(1) ( 2 ) (3) ( 4 ) ( 5 )

04. Eu sou mandão (digo às pessoas o que fazer em vez de pedir).
( 1 )
(2)
( 3 )
(4) (5)

05. Eu reclamo freqüentemente.

(1) ( 1 ) ( 3 ) ( 4 ) ( 5 )

06. Eu falo (interrompo) quando alguém está falando.
(1) ( 2
(3)
(4) ( 5 )

07. Eu pego ou uso coisas que não são minhas sem permissão.

(1) ( 1 ) ( 3 ) ( 4 ) ( 5 )
08 . Eu gosto de contar vantagem.

$\begin{array}{lllll}\text { (1) (1) (2) } & \text { ( } 3 \text { ) }\end{array}$

09. Eu olho para as pessoas quando falo com elas.

(1) ( 1 ) ( 3 ) ( 4 ) ( 5 )

10. Eu tenho muitos amigos.

(1) (2) (3) (4) (5)

11. Eu bato ou brigo quando estou zangado.

(1) ( 2 ) (3) ( 4 ) (5)

12. Eu ajudo um amigo quando ele está machucado ou chateado.

(1) (2) (3) (4) (5)

13. Eu tento animar um amigo que está triste.

(1) (2) (3) (4) (5)

14. Eu olho para as outras crianças de um jeito ameaçador.

(1) (2) (3) (4) (5) 
15. Eu sinto raiva ou ciúme quando outra pessoa está bem.

(1) ( 2 ) (3) ( 4 ) ( 5 )

16. Eu me sinto feliz quando a outra pessoa está bem.

(1) ( 2 ) (3) (4) ( 5 )

17. Eu ridicularizo os erros/defeitos das outras pessoas.

( 1 ) ( 2 ) ( 3 ) (4) (5)

18. Eu sempre quero ser o primeiro.

(1) (2) (3) (4) (5)

19. Eu quebro promessas.

(1) (2) (3) (4) (5)

20. Eu falo para as pessoas que elas são bonitas.

( 1 ) ( 2 ) ( 3 ) (4) ( 5 )

21. Eu minto para conseguir o que quero.

(1) (2) (3) (4) (5)

22. Eu incomodo as pessoas para deixá-las zangadas.

( 1 ) ( 2 ) ( 3 ) ( 4 ) ( 5 )

23. Eu me aproximo das pessoas e inicio uma conversa.

(1) ( 2 ) (3) (4) (5)

24. Eu digo "muito obrigado" e me sinto feliz quando alguém faz um favor para mim.

(1) ( 2 ) (3) (4) (5)

25. Eu gosto de ficar sozinho.

(1) ( 2 ) (3) (4) (5)

26. Eu tenho medo de falar com as pessoas.

(1) ( 2 ) ( 3 ) ( 4 ) ( 5 )

27. Eu sei guardar segredo.

(1) (2) (3) (4) ( 5 )

28. Eu sei como fazer amigos

(1) ( 2 ) (3) (4) (5)
29. Eu firo os sentimentos dos outros de propósito (eu tento deixar as pessoas tristes).

(1) (2) (3) (4) (5)

30. Eu zombo dos outros.

( 1 ) (2) (3) ( 4 ) (5)

31. Eu sou fiel aos meus amigos.

(1) ( 2 ) (3) (4) (5)

32. Eu olho para as pessoas enquanto elas falam comigo.

( 1 ) (2) (3) (4) (5)

33. Eu acho que sei tudo.

(1) (2) (3) (4) (5)

34. Eu compartilho o que tenho com os outros.

(1) ( 2$) \quad(3) \quad(4) \quad(5)$

35. Eu sou teimoso.

(1) (2) (3) (4) (5)

36. Eu ajo como se eu fosse melhor do que as outras pessoas.

(1) ( 2$) \quad(3) \quad(4) \quad(5)$

37. Eu demonstro meus sentimentos.

(1) ( 2 ) (3) (4) (5)

38. Eu penso que as pessoas estão

implicando comigo quando elas não estão.

(1) (2) (3) (4) (5)

39. Eu faço barulhos que incomodam os outros (arrotando, fungando).

(1) (2) (3) ( 4 ) (5)

40. Eu cuido das coisas dos outros como se fossem minhas.
(1) ( 1 ) (3) (4) ( 5 )

41. Eu falo muito alto.

(1) (2) (3) (4) (5)

42. Eu chamo as pessoas pelos seus nomes.

( 1 ) (2) (3) (4) (5) 
43. Eu pergunto às pessoas se posso ajudálas de alguma forma.

(1) (2) (3) (4) (5)

44. Eu me sinto bem se ajudo alguém.

(1) (2) (3) (4) (5)

45. Eu tento ser melhor que todo mundo.

(1) (2) (3) (4) (5)

46. Eu faço perguntas quando converso com outras pessoas.

(1) ( 12$) \quad(3) \quad(4) \quad(5)$

47. Eu vejo meus amigos com freqüência.

(1) (2) (3) (4) (5)

48. Eu brinco sozinho.

(1) ( 2 ) (3) ( 4 ) (5)

49. Eu me sinto sozinho.

(1) ( 2 ) (3) ( 4 ) (5)

50. Eu me sinto mal quando machuco ou magôo alguém.

(1) (2) (3) (4) (5)

51. Eu gosto de ser o líder.

(1) (2) (3) (4) ( 5 )

52. Eu participo das brincadeiras com as outras crianças.

(1) (2) (3) (4) ( 5 )

53. Eu entro muito em brigas.

(1) ( 1 ) (3) ( 4 ) ( 5 )
54. Eu tenho ciúme das outras pessoas.

(1) (2) (3) (4) (5)

55. Eu faço coisas legais para as pessoas que são legais comigo.

(1) (2) (3) (4) (5)

56. Eu pergunto para os outros como eles estão, o que eles têm feito, etc.

( 1 ) ( 2 ) (3) ( 4 ) (5)

57. Eu fico com os outros muito tempo (esgoto a paciência deles).

(1) ( 2 ) (3) (4) ( 5 )

58. Eu explico as coisas mais do que é necessário.

(1) ( 2 ) (3) (4) ( 5 )

59. Eu dou risada quando as outras pessoas contam piadas ou histórias engraçadas.

(1) (2) (3) (4) (5)

60. Eu acho que vencer é tudo.

(1) (2) (3) (4) (5)

61. Eu machuco ou magôo as pessoas quando brinco com elas.

(1) ( 1 ) (3) (4) ( 5 )

62. Eu quero acabar com alguém que me machuca ou magoa.

(1) (2) (3) ( 4 ) (5) 


\section{Anexo 6 - Teste de Stroop \\ Pré-Teste \\ Reconhecimento de Cor}

Instruções: Vou pedir-lhe para fazer umas tarefas com palavras escritas a cor. Vamos começar por ver as cores [apresentar a Folha de Reconhecimento de Cor]. Esta aqui é [verde], esta [azul], [cinza] e [rosa]. (Marque com um visto $\sqrt{ }$ se a resposta for pronta e sem hesitação, e/ou assinale quaisquer dificuldades).

\section{RECONHECIMENTO DE COR}

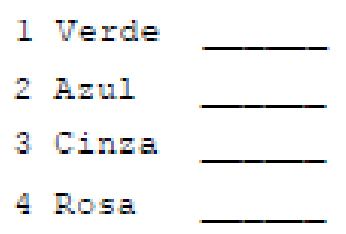

Observações:

\section{Treino de Leitura e de Nomeação de Cor}

Instruções: Agora vamos ver as palavras [apresentar a Folha Treino de Leitura e Nomeação]. Estão escritas nas cores que vimos há pouco [retreinar a nomeação de cor se necessário]. Queria que me lesse estas palavras em voz alta, o mais depressa possível.

RECONHECIMENTO DE COR

1 Rosa

2 Cinza

3 Vercle

4 Azul
NOMEAÇÅO DE COR (a fazer so depols da Lettura de Palavras)

1 Cinza

2 Azul

3 Rosa

4 Vercle 


\section{Leitura de Palavras: Folha de Registo}

Nome:

Idade:

Escolaridade:

Data:

Instruções: Agora temos aqui mais palavras escritas. Queria que me lesse estas palavras em voz alta, o mais depressa que puder. Comece no início da $1 .^{\mathrm{s}}$ coluna, quando acabar passe à $2 \mathrm{.}^{\mathrm{a}}$, depois à $3 .^{\mathrm{a}}$, e finalmente à última. Se se enganar, corrija e continue. Depois de eu dizer "Agora", comece. Entendido? Então atenção: Agora!

Tempo: Dê o sinal de partida ao mesmo tempo que acciona o cronómetro. O tempo limite é de 120 segundos. Diga: "Chega, pode parar" quando o tempo limite chegar ao fim.

Cotação: Marca-se com um visto $\sqrt{ }$ as respostas correctas, com uma cruz $X$ as incorrectas, e com um $C$ as correcções espontâneas. Registe o tempo em que o sujeito realizou a tarefa, ou 120 segundos.

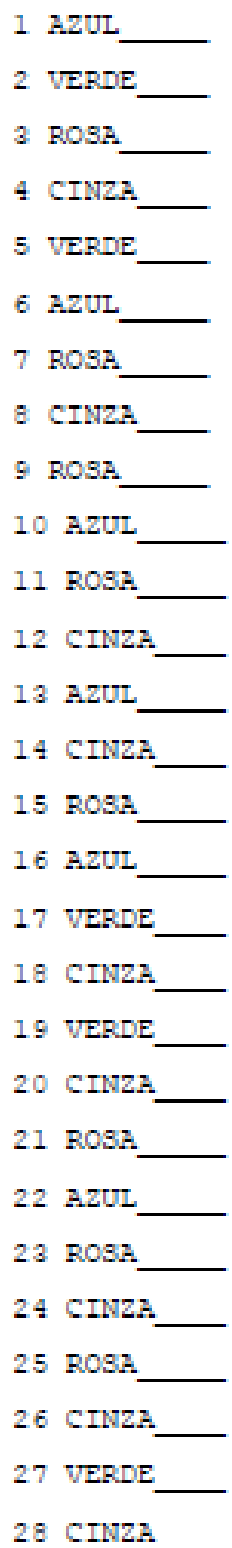

\begin{tabular}{l}
29 VERDE \\
30 AZUL \\
31 ROSA \\
32 AZUL \\
33 CINZA \\
34 ROSA \\
35 VERDE \\
36 CINZA \\
37 VERDE \\
38 AZUL \\
39 ROSA \\
40 CTNZA \\
41 VERDE \\
42 ROSA \\
43 AZUL \\
44 VERDE \\
45 ROSA \\
46 VERDE \\
47 AZUL \\
46 CINZA \\
49 VERDE \\
50 ROSA \\
51 CTNZA \\
52 AZUL \\
53 CINZA \\
54 ROSA \\
55 CTNZA \\
56 VERDE \\
\hline
\end{tabular}

\begin{tabular}{l}
57 ROSA \\
58 VERDE \\
59 AZUL \\
60 CINZA \\
61 ROSA \\
62 CTNZA \\
63 AZUL \\
64 CTNZA \\
65 ROSA \\
66 AZUL \\
67 ROSA \\
68 CTNZA \\
69 AZUL \\
70 VERDE \\
71 CTNZA \\
72 AZUL \\
73 CTNZA \\
74 AZUL \\
75 ROSA \\
76 VERDE \\
77 AZUL \\
78 VERDE \\
79 AZUL \\
80 VERDE \\
81 ROSA \\
82 VERDE \\
83 CTNZA \\
84 ROSA \\
\hline
\end{tabular}

\begin{tabular}{l}
85 VERDE \\
86 CINZA \\
87 ROSA \\
86 CINZA \\
89 AZUL \\
90 CINZA \\
91 VERDE \\
92 ROSA \\
93 VERDE \\
94 ROSA \\
95 AZUL \\
96 VERDE \\
97 CINZA \\
98 AZUL \\
99 VERDE \\
100 ROBA \\
101 VERDE \\
102 CTNZA \\
103 VERDE \\
104 AZUL \\
105 CINZA \\
106 AZUL \\
107 VERDE \\
106 ROBA \\
109 AZUL \\
110 VERDE \\
111 ROSA \\
112 AZUL \\
\hline
\end{tabular}




\section{Nomeação de Cor: Folha de Registo}

Treino, Instruções: Agora vamos fazer uma tarefa diferente [apresentar a Folha Treino de Leitura e Nomeação]. Em vez de ler as palavras, queria que me dissesse a cor da tinta em que estão impressas. Assinalar as respostas na página inicial. [Passar ao teste propriamente dito depois de se ter assegurado que o sujeito compreendeu o que é preciso fazer. Se necessário, repetir o treino, e explicar que esta tarefa exige concentraçäo. Tente motivar o sujeito a realizar bem a tarefa, enbora sem criar receio de insucesso.]

Instruções: Vamos fazer o mesmo com mais palavras. Queria que me dissesse a cor da tinta em que estão impressas as palavras, o mais depressa que puder. Comece no início da $1 .^{\mathrm{a}}$ coluna, quando acabar passe à 2.", e assim sucessivamente. Se se enganar, comja e continue. Como há pouco, só começa depois de eu dar o sinal (dizer "agora"). Entendido? Atenção: Agora!

Tempo: Dê o sinal de partida ao mesmo tempo que acciona o cronómetro. O tempo limite é de 120 segundos. Cotação: Marcar com um visto $\sqrt{ }$ as respostas correctas, com uma cruz $\mathrm{X}$ as respostas incorrectas, e com um $\mathrm{C}$ as correcções espontâneas. Marque o tempo que demorou a realizar a tarefa, ou 120 segundos.

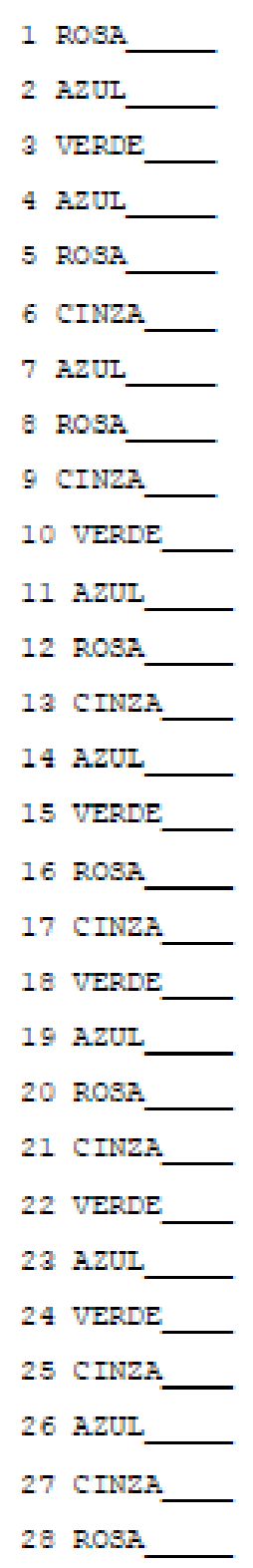

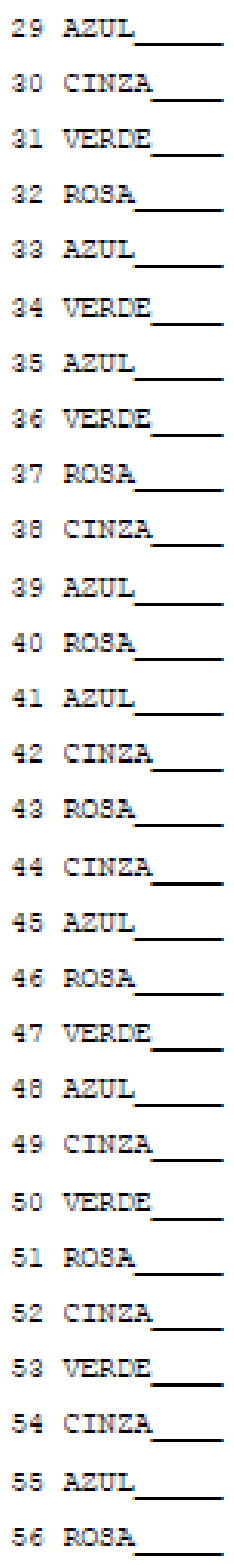

57 AZUL
58 CINZA
59 ROSA
60 VERDE
61 CINZA
62 ROSA
63 VERDE
64 AZUL
65 VERDE
66 CINZA
67 AZUL
68 VERDE
69 ROSA
70 AZUL
71 ROSA
72 VERDE
73 AZUL
74 CINZA
75 VERDE
76 AZUL
77 ROSA
78 CTNZA
79 VERDE
80 ROSA
81 CINZA
62 AZUL
83 VERDE
84 AZUL

Incorrectas $(X)=$

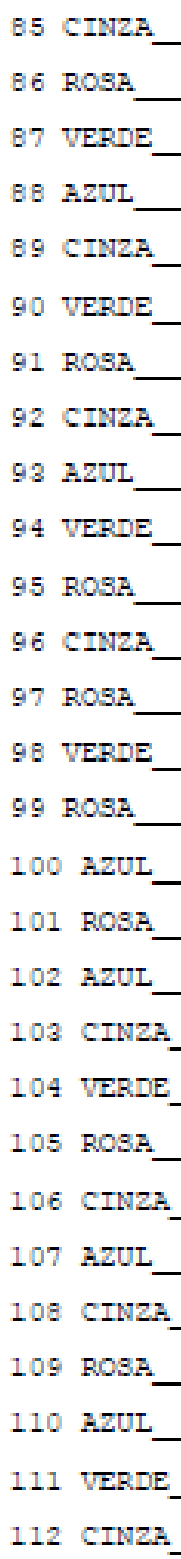


$x x x x$

XXXX

XXXX

XXXX 
ROSA

CINZA

VERDE

AZUL 


\begin{tabular}{|c|c|c|c|}
\hline AZUL & VERDE & ROSA & VERDE \\
\hline VERDE & AZUL & VERDE & CINZA \\
\hline ROSA & ROSA & AZUL & ROSA \\
\hline CINZA & AZUL & CINZA & CINZA \\
\hline VERDE & CINZA & ROSA & AZUL \\
\hline AZUL & ROSA & CINZA & CINZA \\
\hline ROSA & VERDE & AZUL & VERDE \\
\hline CINZA & CINZA & CINZA & ROSA \\
\hline ROSA & VERDE & ROSA & VERDE \\
\hline AZUL & AZUL & AZUL & ROSA \\
\hline ROSA & ROSA & ROSA & AZUL \\
\hline CINZA & CINZA & CINZA & VERDE \\
\hline AZUL & VERDE & AZUL & CINZA \\
\hline CINZA & ROSA & VERDE & AZUL \\
\hline ROSA & AZUL & CINZA & VERDE \\
\hline AZUL & VERDE & AZUL & ROSA \\
\hline VERDE & ROSA & CINZA & VERDE \\
\hline CINZA & VERDE & AZUL & CINZA \\
\hline VERDE & AZUL & ROSA & VERDE \\
\hline CINZA & CINZA & VERDE & AZUL \\
\hline ROSA & VERDE & AZUL & CINZA \\
\hline AZUL & ROSA & VERDE & AZUL \\
\hline ROSA & CINZA & AZUL & VERDE \\
\hline CINZA & AZUL & VERDE & ROSA \\
\hline ROSA & CINZA & ROSA & AZUL \\
\hline CINZA & ROSA & VERDE & VERDE \\
\hline VERDE & CINZA & CINZA & ROSA \\
\hline CINZA & VERDE & ROSA & AZUL \\
\hline
\end{tabular}

